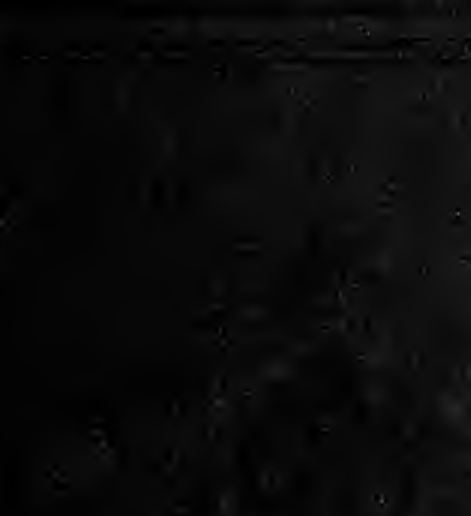




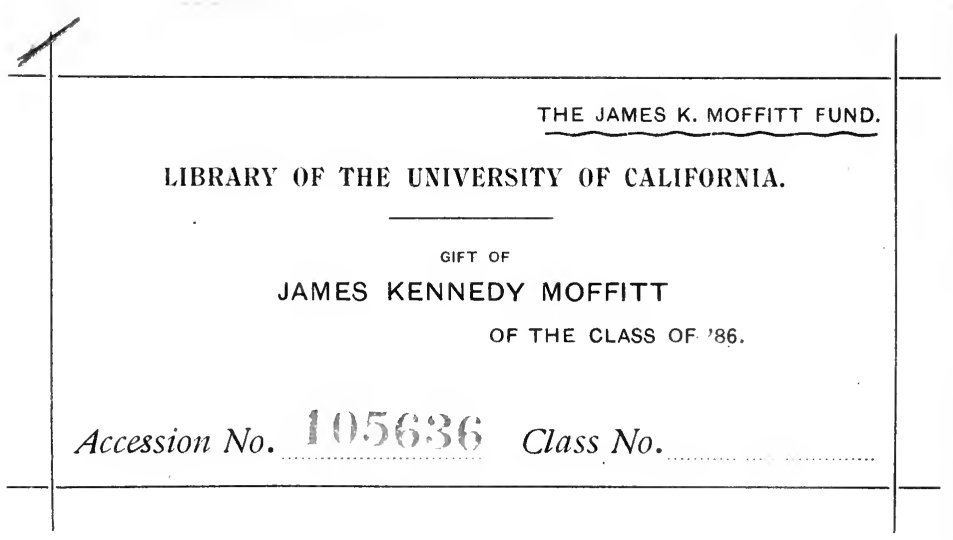


$\therefore$ 



\section{PHILOSOPHY AND LIFE}

\section{AND OTHER ESSAYS}

BY

J. H. MUIRHEAD, M.A.

II

PROYESSOR OF MENTA AND MORAL PHILOSOPHY IN THE UNIVERSITY OF BIRMINGHAM

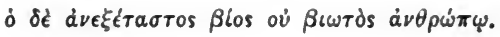

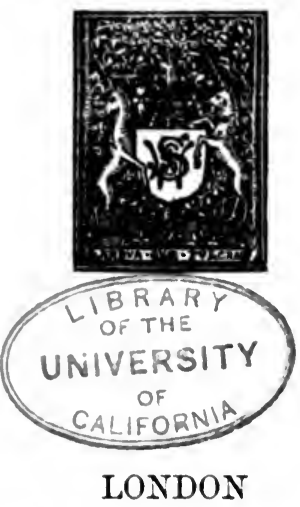

SWAN SONNENSCHEIN AND CO., LIM.

PATERNOSTER SQUARE

1902 


$$
\begin{gathered}
\text { BD4-1 } \\
M_{8}
\end{gathered}
$$

Marfit 
To

M. T. M. 


\section{AUTHOR'S NOTE.}

OF the first series of Essays in this volume, about one half have already appeared in the Fortnightly Review and other journals, and are republished with the kind permission of the Editors. They were all written in the first instance as lectures for various more or less popular societies.

The four more technical papers at the end were read some years ago before the Aristotelian Society in London, and are reprinted partly from Mind and partly from the Proceedings of that society. They had for their aim the closer connexion of Logical Science with the concrete problems of knowledge.

Birmingham, March 25th, 1902. 


\section{CONTENTS.}

\section{ETHICAL.}

I. Philosophy and Life $\quad$ - . 1

II. Professor William Wallace $\quad$. $\quad$. 20

III. Robert Louis Stevenson's Philosophy of Life 37

IV. Abstract and Practical Ethics - $\quad$ - 58

V. What Imperialism Means $\quad$ - $\quad$ • $\quad$. 79

VI. The Science of Poor-Law Relief • • $\quad$ • 98

VII. Modern Methods of Temperance Reform . 118

VIII. A Liberal Education $\quad . \quad 137$

IX. Psychology and Education . . . 156

LOGICAL.

I. The Place of the Concept in Logical Doctrine 183

II. The Goal of Knowledge . $\quad$ - . 205

III. Hypothesis $\quad$ • $\quad$ • $\quad$ • 230

IV. Is Knowledge of Space a Priori? $\quad . \quad 264$ 


\section{Digitized by the Internet Archive in 2007 with funding from Microsoft Corporation}




\section{ETHICAL.}




$$
\text { - }
$$




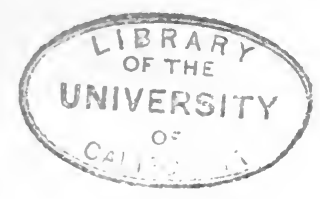

\section{PHILOSOPHY AND LIFE.}

\section{I. \\ PHILOSOPHY AND LIFE. ${ }^{1}$}

WHEN it was proposed to found a school of Ethics and Social Philosophy in London, the most common objection that the promoters had to meet was this-that a School of Philosophy had no definite relation to life. Ethical Societies, it was said, meet a practical demand. The School of Economics, the analogy of which suggested a School of Ethical Philosophy, also appealed to certain definite classesto bank clerks, Government officials, and to the great business world generally; above all, it appeals to social and political reformers. But it did not seem so obvious that the subjects we proposed to deal with here had any similar clientele to draw upon.

This objection seems to reflect the common view of the relation of philosophy to life. It is pretty generally admitted that life is a good thing for the philosopher. It broadens him, and soon convinces him that "there are more things in heaven and earth than are dreamt of in his philosophy." But people are not at all so clear that philosophy is a good thing for life. There are some, indeed, who go so far as to doubt whether

1 Lecture delivered at the Passmore Edwards Settlement, London, in 1899. 
philosophy has any connection with the serious questions of everyday life-indeed, whether it is a serious subject at all. They regard it as a kind of pastime, a kind of "blind man's buff," in which able and leisurely persons from the University sometimes indulge. This seems to have been the view that the late Charles Bowen took of it when he defined metaphysics as "groping about in a dark room for a black hat which was not there!"

There are others who take a more serious, if not a more favourable, view of the function of philosophy. They think that philosophy has a definite relation to life, but that this relation is rather of a negative than a positive character, inasmuch as from the time of Socrates downwards it has been on uncomfortable terms with some of our common opinions and conventions. It has got a reputation for saying nasty things about those useful and comfortable assurances on which our ordinary life is based. Indeed, the philosopher is openly suspected by some of entertaining designs upon our most cherished convictions, and people nervously grip their principles when he is by, as they grip their purses when pickpockets are about.

This seems to be the view which was held by the late Master of Balliol, if one may judge by some passages in his Life and Letters. Philosophy, he thought, was a very good thing, because of the tendency among philosophers to attack common-sense opinions and set up idols of their own in place of them. This could only be counteracted by a little more philosophy, which was therefore chiefly useful in dispelling the illusions which it had itself created. A little metaphysics, he thought, was useful in order to get rid of 
metaphysics-a view which reminds one of Professor Sidgwick's humorous account of the philosopher as a species of policeman performing a wholesome function in protecting us from other philosophers.

All these views seem to me to be founded upon a misunderstanding of what philosophy really is, and before I approach my subject more definitely I wish to ask what we are to understand by philosophy. This seems more necessary in London, because there is a certain confusion, even in the minds of people who are well disposed to it, as to what it really is. Thus there is a tendency to identify it with psychology, or mental science, the name by which, indeed, it commonly goes in the newer schools. Now if by psychology we mean what J. S. Mill meant by the word-e.g. in his LogicI have no objection to this use, for what Mill meant by it was philosophy in general. But psychology in recent years has come to be something much more special than this. It has come definitely to be recognised as a special science with experimental methods, and even laboratories and apparatus of its own.

With this youthful science we have no quarrel here. On the contrary, we have great expectations in connection with it. I merely wish to point out that it is not philosophy, and perhaps I shall best make clear to you what I mean by the latter if I try to bring it into sharp contrast with the science of psychology as just defined.

Philosophy and psychology are both mental, but psychology has two characteristics in which it contrasts with philosophy. In the first place it is empirical, by which I do not mean anything disrespectful-I mean simply that it treats the facts of life as events, events that happen like other events in the world, in time, 
with origins, causes, courses of their own. The aim of psychology is to analyse these events, seeking for their causes in other events, discovering identities between them and others of a simpler or, again, a more complex type. This feature may be said to unite psychology with other sciences. All the sciences with which we are familiar deal with events, with phenomena, as they are called; they analyse and explain phenomena.

But, secondly - and this differentiates it from other sciences - the object of psychology is mind. The events take place in the mind; they are subjective, individual, personal to each of us, being generally opposed, as such, to the "objects" of the external world with which the physical sciences deal.

Now I wish to contrast this other mental science, or theory of the mind, in these respects with psychology.

In the first place, I wish you to notice that it is not empirical. It treats of the mind, but it does not treat of the mind as a product, as something produced by causes. How does it treat of it? It treats of the mind as a producer, as a creator, as the creator of science and literature, of morality and society, of art and religion. Hence it is sometimes called speculative, by which is not meant anything transcendental or specially recondite, but merely that it treats of these things, not from the point of view of cause and effect, but of their purpose, meaning, and significance. It asks, What is the significance of these things? What do they mean for the human soul? Philosophy tries to trace, as it were, the lines of mind in those great realities. It tries to trace the lines of its own nature as reflected in them. Remembering this, we under- 
stand what Plato meant when he defined the philo-

- sopher as the "synoptic man." He is the man who tries to see all these things from the point of view of their unity in the human mind which created them.

In the second place, philosophy treats the mind, as seen in science, art, religion, morality, not as your mind or as my mind, not as mind subjective, but as mind objective. I do not mean, of course, that these things have an existence outside of mind. I do not, myself, believe they have. They are not external existences, like this room. They are mental, mental possessions, subjective realities if you like; but notice that they are realities upon which all minds meet. They are not the possession of any one individual mind; they are the common ground of the mind of humanity. This is a commonplace with regard to science; we all admit that science is the ground upon which we all can meet. To a lesser extent it is admitted of art. It is so, for instance, when we describe the subjects of university education, the universal subjects, the subjects upon which societies of students, universitates, meet, as "science and arts." By-and-by, let us hope, people will also meet on morality and religion, when, perhaps, these will be more frankly and fearlessly admitted as subjects of university education. In the meantime it is none the less true, because people differ on these matters, that they are objective, that they are real, that they are the ground for the meeting of minds. This is why we sometimes speak of philosophy as the science of reality. It is the science of tnose great thingsthe great realities of life, and their unity in mind. We endeavour to see what they mean to us, what is their rationality, their reality. Here, then, we have 
our definition, such as it is, of philosophy. Philosophy is the speculative science of mind, or it is the theory of reality. I prefer the latter definition-the theory of reality.

With this definition before us, let us now come to our main question: What is the relation of this theory of reality to life and practice? Before I attempt to give a positive answer to this question, let me mention what it is not, in order that you may not expect too much from it, and so be disappointed when I come to describe what it is. Philosophy does not, as is sometimes supposed, aim directly at edification and construction. Philosophy is sometimes supposed to be a species of preaching, a kind of glorified sermon, exhorting us to believe in religion, morality, and the like. There are, of course, philosophical discourses which are also the most glorious of sermons -e.g. the Phoedo and the Apology of Plato. But philosophy does not aim directly, like a sermon, at creating belief in these things-at producing faith. As Hegel said, if it did, it has come too late into the world. Fortunately, belief in these things exists already, and philosophy accepts that fact. It accepts as its supposition the existence of faith in science, art, morality, religion. Its dictum, indeed, might be said to be what the mediæval Church took as its motto, "Credo ut intelligam"-I believe in order that I may go on to understand. Philosophy accepts these beliefs, and then it tries to understand them. But now I wish you to note that, while our object is not faith, but knowledge and understanding, this understanding may have an important influence upon the beliefs, because a belief which is understood is something different from that belief before it is understood, and it is in 
this direction that we must look for the real function of philosophy, for its relation to life.

Remember, please, the definition I have given of philosophy; it is the theory or science of reality. And just ask yourselves for a moment what is the relation of theory generally to the particular reality with which it deals, because I claim that philosophy has the same relation to those realities of which I have spoken as theory in general has to the facts with which it deals. What is that relation? In common language we often speak of fact and theory as something quite different. Your breathing this air here is a fact. That stands on one side. On the other there is the chemical theory of your respiration. This we take to be something quite different, dealing with what takes place in the air when it has gone through your lungs. More closely looked at, this distinction, however, is seen to be all wrong. The theory of a fact is only the fact more thoroughly realised. When you come to realise what you are actually doing in breathing this air, you understand the fact of your breathing this air very much better than before. You understand, for instance, that if $I$ were to shut the window and keep you here till midnight, you would be all very ill indeed, while if I kept you till the middle of the week none of you would survive to tell the tale. In this way we may say you realise the fact. It is a different fact to you, a clearer fact, a deeper fact, a more vital fact. What you have done in trying to understand it is to vitalise the fact, to bring it home to yourself, to assimilate it.

Now, I wish you simply to apply to philosophy and the great facts with which it deals what I have been saying about the relation of fact to theory in general. 
It is just the same relation. Philosophy tries to understand, let us say, what is meant by science and art, what is meant by morality, what is meant by society and the State, what is meant by religion. And, in doing so, it helps us to realise more fully what these facts are. We, as it were, translate them into our intellectual medium. With what object? Not to get away from the facts into some pure abstract region, but to get closer to them, to make them more of facts to us, to broaden them out through understanding their bearings. Nettleship brings this view of the relation of philosophy to life vividly home to us in a fine passage in his recently published lectures by quoting Novalis's account of it. "Philosophiren," said Novalis, "ist dephlegmatisiren, vivificiren." To philosophize is to get rid of your phlegm, to rid yourself of what lies between you and the fact. The great realities of which philosophy treats are brought nearer to us, acquire a vividness and intimacy that they previously lacked.

Now, you may say this is a very general and abstract description, and I propose in the rest of this lecture to try to come a little nearer to the subject; and I think I shall best do so by asking, Are there any special circumstances of the times in which we live which make this service of especial value to people who wish to live rationally and well? Such circumstances I find in some of the characteristics of the age, which it has become almost a commonplace to note. I shall mention two.

In the first place, we are frequently told that it is an age of specialisation, and everybody knows that this is true. We have all got to live, and we must live under the conditions of the time we are living 
in; and one of the chief of these conditions is that we should take up something special. We have got to turn our backs on other things, and devote ourselves to one corner of reality, one bit of the world-becoming specialists, and, if possible, experts. This, of course, is a necessary and a very advantageous mode of dealing with our business, dividing labour; but it brings with it its own dangers. I do not mean that the great men, the great scientific discoverers, the great artists, novelists, religious teachers are really apt to forget that they are dealing only with a part of reality, but that the lesser leaders, and those of us who are not leaders at all, are very apt to forget it. We are apt to conceive of our bit as though it were the universe. It is from this misunderstanding that the ordinary catchwords of our time- "art for art's sake," "science for science's sake," "business is business," and such other mischievous half-truths, or no truths-come. We try to set up one feature of reality against the whole, and this has, of course, the result that what lies outside of our particular cornerour "Fach," as the Germans say-is apt to lose reality and significance; it is apt to become shadowy and unreal to us. But this is not all. By a peculiar Nemesis, a kind of irony in nature, it is not only the great whole which lies beyond our part that tends to lose significance and meaning, but our own part itself is apt to become insignificant when it is treated in this way. Art, for instance, when taken by itself and made its own object, is apt to become mere photography-perhaps something worse; science and literature are apt to become pedantry; religion is apt to become ceremony; morality mere convention; business money-making, and so on through all of 
them. What is not seen to be penetrated by the life of the whole seems to lose its meaning and be emptied of reality for us. There is thus a very real need to try, while doing our best to become specialists in one branch of reality, to keep ourselves in touch with the whole to which it belongs. As Goethe said :

\section{"Sich dem Halben zu entwöhnen,}

Und im Ganzen Guten Schönen

\section{Resolut zu leben."}

To do this on easy terms, and superficially, is what is commonly known as culture; to do it seriously, systematically, deeply and effectively, is what we mean by philosophy. I have distinguished between these two; but, of course, there are all degrees of culture. And culture which takes itself seriously tends to become philosophy. This was so with Goethe himself, of whom Heine used to say that he wished that he would read something else besides Spinoza; and I suppose the greatest poets-Shakespeare perhaps excepted, who had philosophy in himself-have been also philosophers in a more than general sense.

Of course, it is very easy to mistake what I have been saying, and to ask me if I seriously mean that, in order to keep ourselves alive, in order to keep the world fresh and vivid before us, we have got to study philosophy in the technical sense. I need hardly say I do not mean that. Just as it is not necessary, in order to do public service, to do service in publicbut what is essential is to do whatever service we undertake in a public spirit-so it is not necessary, in order that a life may be philosophical, to read and talk philosophy.

What I wish to press upon you is the necessity of living one's own particular life in the light of the 
whole, of trying to see it from the point of view of its significance-its significance for life in general. I should be sorry to think that for this purpose it is necessary to have a technical knowledge of philosophy. What is necessary is to try to live as deeply and to think as broadly and as truly of our special walk in life as possible.

This is the first point. The discontinuity, the disconnectedness, the fragmentariness of modern life make philosophy, in the sense I have been trying to explain, more or less of a necessity. The parts of life, as it were, which previously, in a more simple age, were held instinctively together, tend in the stress of modern life to fall apart; and, in order to keep them together, we have to make something of an effort. And what we propose to do in this school, as far as I understand it, is to call upon you, in connection with particular subjects, to make this effort to keep the whole before your minds.

But, secondly, and coming nearer, perhaps, to some of us, there is another feature of our time which has unfortunate results-namely, that we have all got more or less to talk and to write. This is an age of talking, and it is an age of writing; and those of us who have to bear the burden of the age in this respect, perhaps to live by talking and writing, have to get something to talk and write about. We have to get it by hook or crook, and often have not much time to get it in. The consequence is that we are apt to take up with hasty, one-sided views of things. One reason is that they are easier to get hold of. Another is that they "go down" better. But, take it as you like, there is this fatal tendency in our ideas to be one-sided and partial. This is amply illustrated in the fields of 
moral philosophy itself. Justice and charity, for instance, are opposed to one another by some ethical writers. Happiness and duty is a common antithesis; the individual and the state- "Man versus the State," as Mr. Spencer puts it-freedom and government, are others. You understand what I am driving at-the ordinary antitheses we meet with in everyday literature tend to cause a certain one-sidedness in our views of things, and to keep us out of sight of the whole truth. Nor, of course, is this altogether an intellectual matter. You cannot keep ideas out of life, you cannot have one-sided thoughts, which are mere thoughts. They enter into life, and they tend to make life one-sided and disorderly.

We hear a great deal, for instance, of political corruption in America; but if we look a little closer, we see, and people who have been there tell us, that, after all, the Americans are a very honest, straightforward people. And if we ask, "How is it they let their politics get into such a mess?" we shall probably find that it is greatly the result of false theory. As a friend of mine who came back from America recently put it, "The American people are not a bad sort of people. What is wrong is not their morals, but their philosophy. They are suffering from bad metaphysics." They have got it into their heads that liberty means letting things alone; and they only get on at all because, after they have done this for a long time, and the mess that results becomes very bad, they bestir themselves, and get things put a little right.

But we do not require to go to America for the attempt to make half-truths pass current for whole truths. I noticed the other day that a duke, who was making a speech in connection with the recent County 
Council elections, told us what was wanted in London was practical men who did not suffer from that form of cerebral derangement which people call ideals. It appeared that we have got to break with ideals before we can get our cities managed to our hearts' content. And a bishop, I notice, has been exhorting his diocese to remember that politics is not piety, as though there was any piety worth a halfpenny which was not political, which had not an eye to the good of fellow-citizens, and vice-versâ.

You see these half-truths are not as harmless as people commonly suppose. They have an edge upon them, and what we have to do is to try to turn that edge by making them into whole truths. I suppose

- this is what Jowett had in view when he told us that a little metaphysics was a very good thing, because it enabled us to get rid of metaphysics. Only I should be inclined to lay more emphasis on the quality of the metaphysics. It must be good metaphysics, and the value of good metaphysics is that it helps us to get rid of bad. Moreover, it may be useful to remind you that good metaphysics cannot be got by a smattering at the University. It is a serious matter; as Socrates said, our whole lives are not sufficient for these discussions. Indeed, I should define philosophy as a lifelong conflict with one-sided ideas. It is the effort to see things in their connection, to see things as a whole, to get rid of what Hegel called "soulless abstractions," to get at the concrete thing; and the concrete thing, as we have seen, is the thing, not in its crude form, nor in the form in which it first presents itself to us, but in the form in which it has been penetrated by our thought-made our own, by our having thought it through. 
The answer to speakers like those I have quoted is really to be found in the saying of Bishop Berkeley. Unlike the bishop I have just referred to, Berkeley was a philosopher as well as a bishop, and he says somewhere that, "whatever people may think, the man who hath not deeply meditated on the human mind and on the summum bonum may possibly make a thriving earthworm, but will indubitably make a sorry politician and statesman."

There is one science which is very near ethics and political philosophy, from which I should like, if time permit, to illustrate for a moment what I have been trying to say. I mean the science of political economy. I have often been asked what is the relation of ethics to economic problems, which are pressing upon us more than ever at the present time. Last winter I happened to give a course of lectures in Birmingham upon "Work and Wages," and I set myself, with a view to defining the relation of ethics to economics, definitely to notice whether, and at what point, the subject I was dealing with for the moment broke away from political economy and became an ethical problem. I was surprised to find, with every question I took up, that I had at a certain point to say: "Here the question is one of ethics, and, as I am lecturing upon political economy, I cannot go into that now, and must leave the matter inadequately treated."

Suppose the subject was the age of children beginning to work in factories. Some economists tell us that production is increased by employing boys and girls in factories. It is an extremely difficult thing to say whether production really is increased by this, whether economically it is a good thing. But the moment we turn to the ethical side and ask, Is it good 
for human happiness that children should be shut out of a true liberal education?-then the question takes on a different look. In other words, the question of mere production tends to fall into the background, the question of the end or meaning of it takes the front place.

The same is true in relation to the question, What trade unions have done. It is extremely difficultmuch more than you would suppose at first-to prove that trade unions have actually raised wages. The more you hear and see and read, the more difficult you find it to answer that economic question. But when you come to the other side, to the ethical question, Have trade unions raised the working classes? have they made the working classes more respected and selfrespecting? - that is a very different problem, and I have no difficulty in answering that.

"The living wage" is another case. It is very difficult to prove economically that the living wage is a good thing, though I think the case here is stronger than the economic argument in favour of trade unions. But when you come to the ethical question, and ask what the depression, the degradation, of sinking below the living wage means for the individual, for his wife and family, then you come to a clear issue. The whole question takes a new aspect; it becomes a more serious and interesting one.

The ideal of general progress is another ethical question, which it has struck me that economists tend to ignore, to the detriment of their treatment of their own specific problem. What is meant by progress in the working class, or any other class? Does it mean merely increase of desires? I read a good many political economy books, and those that are better 
disposed denounce the want of desires, the want of a standard of life, the want of tastes among the working classes; they suggest that the great thing is to create desires in the working classes, in order that they may demand higher wages. They appeal to what the Germans call the "verdammte Bedürflosigkeit" in the working classes. But surely we cannot treat this increase of desires as itself a good, apart from the quality and organisation of the desires. It is easy enough to create desires and tastes. I take it a taste for loafing and the racecourse is easily enough acquired. It is the quality of the desires that we should look to. The need of the working classes is the chance of developing better desires and of subordinating them to a true conception of life. I need not go on; the general conclusion is plain. At every point our social problems open out upon ethical problems, and no one can deal with them satisfactorily who "hath not deeply meditated upon the human mind and upon the summum bonum."

It was this conviction which led me to take an interest in the foundation of a School of Ethics and Social Philosophy. I think, if the school can take up that position, can force those who are interested in such questions to face them from this point of view, to treat laws and institutions from the point of view of their effect upon human character and the ultimate ideal of the community, they will have done something worth doing, and something not yet done in connection with our social problems in London.

I have said a great deal about philosophy and the study of philosophy; and perhaps there are some here who are rather more of beginners than myself, to 
whom, without offence, I might venture to offer, in closing, one or two pieces of practical advice on this head.

The first piece of advice that it strikes me to give, from my own experience and circumstances, is, Do not begin at the end; do not begin at the difficult things in philosophy. Do not begin, for instance, with Hegel's Logic, or even with Bosanquet's Logic. If you do that, you will be like one who sets about the study of mathematics beginning with the differential calculus. Those who are beginners must be content with something a little more elementary and attractive-the Dialogues of Plato must come before the Critiques of Kant. About these there is now no difficulty, with the translations and commentaries that we have in English. Following on the Dialogues come the Ethics, with the first two and the last book of the Politics of Aristotle. Of modern books, besides old Locke, there are the Principles of Bishop Berkeley, from which I have quoted, and the Essays of Hume-all in cheap editions now. There are Mill's works-his Liberty, his Utilitarianism, his Discussions, the last book of the Logic, not sufficiently read by students.

Then there is Caird's Hegel, in Blackwood's Philosophical Classics; Mr. Bosanquet's smaller works; all that Professor Wallace has written-beginning with his biographies of Schopenhauer, Kant, and Epicurus; and perhaps more than all, the recently published Philosophical Lectures and Remains of $R$. L. Nettleship, beginning with the Biography by his friend Professor Bradley. From these last alone you will have a very fair idea of what philosophy is, what a fine mind like Nettleship's made of it, and what a fine man it made of him. 
In the next place, take my advice, and do not read Elements and Outlines. You may be sure that this advice is quite disinterested, because I have written Elements myself. Get to the great writers. Go to their own works, for philosophy is really not a dogma, not a system of doctrines. It is a way of looking at the world of knowledge and experience which you can best acquire by trying to put yourself in the position of a great mind which has consciously adopted it.

Do not be alarmed at the multitude of philosophers and philosophies. It does not really matter much which of the great writers you take up-Plato, Aristotle, Spinoza, Kant, Berkeley, Hume, Mill, Green. The man who refuses to read a particular philosopher because he does not give us "philosophy," Hegel said, is like the man who refuses to take cherries or pears because they are not "fruit." There is no such thing as philosophy in general, any more than there is fruit in general.

You may begin really with any. There is none of them, we may admit, that has a divine origin, and is infallible; and, as Socrates says in the Phoedo, when we cannot get a divine discourse to sail in, as in a ship, we must take the best human discourse that is open to us, and, greatly daring, sail on it through life as upon a raft.

The last thing that suggests itself to me is: Do not suppose that, in order to live and think philosophically, you require to think about things that you find in the philosophical text-books. Do not, e.g., think that it is necessary to follow "the dance of bloodless categories" that Hegel leads us in his Logic. Here, also, it does not matter where you begin. Listen to what Nettleship, whose Remains I quote again, says 
on this: "If I had to begin over again, I should like to try to master the elements of a few big things. Till I have done this, the rest is all confusion, and talking about it is beating the air. And whenever I at all understand the elements, I seldom find much difficulty in finding applications everywhere. Anything presents every kind of problem; and I can't help thinking that it would be much better for many metaphysically minded people if they would think about things which they happen to feel and have real experience of, instead of taking their subjects and lines of thought from other people's systems."

"Anything," he says, "presents every kind of problem." All roads lead to Rome; all subjects followed far enough will take us to the centre. They lead to the Whole; and philosophy is really only a particularly determined attempt to follow out the path of knowledge or experience that any one of us happens to have chosen for himself. 


\section{II.}

\section{PROFESSOR WILLIAM WALLACE. ${ }^{1}$}

THE death of Professor Wallace in February made

1 a great blank among English philosophers. It is one more added to the list of similar losses which the present generation has suffered. W. K. Clifford, T. H. Green, R. L. Nettleship, and now William Wallace. If all these were "happy in the opportunity of their death," inasmuch as they died before any of their natural force was abated, and yet not before they had given evidence of the maturity of their thought, just for that reason we have the more to regret, for we know what we have lost.

As one who had the privilege of reckoning himself among the comparatively small number of Wallace's intimate friends, I may, perhaps, be permitted here to say how great is our personal loss. None who knew him will ever forget the splendid simplicity of his character. It seemed a stroke of irony that he should have been a University professor. No professor was ever less professorial, and it was often difficult to realise in private that he was one of the most learned men of our time. No man-or, at any rate, no University man -ever laid less store by external distinctions. This freedom from conventionality he owed to the large fund of genuine humour which he possessed. He has himself described the kind of humour that goes to the

1 Fortnightly Review, 1897. 
making of a philosopher in the highest sense-" the humour, viz., which strides over the barriers set up by institution and convention between the high and the humble, and sees man's superficial distinctions overpowered by a half-grim, half-jubilant Ananke." This kind of humour he himself possessed in no small measure. He was a fellow-countryman of Burns. He valued men and women for what they are. His standard was character. All else, wealth, rank, college honours, were but the guinea stamp-if they were even that-the man was the man for a' that. Even distinctions deeper than those he is thinking of in the above passage, such as those of genuine learning and culture, seemed to be little to him. What he has said of Jowett was true of himself in a striking degree: "He bore in upon his pupils and friends the conviction that beyond scholarship and logic there was the fuller truth of life, and the all-embracing duty of doing their best to fulfil the amplest requirements of their place."

But it is as a lecturer and writer on philosophy that he is generally known, and here we all feel that a teacher of peculiarly ripe scholarship, of extraordinary insight, and very marked individuality, has passed away from us.

To those who live in London his figure has not been unfamiliar for some years past, when he has come to lecture at Toynbee Hall or at the London Ethical Society. The tall and somewhat gaunt outlines, the earnest and thought-worn expression, the perfect mastery of material and language which enabled him to speak for usually over an hour without note or reference, and yet without a slip, the graphic and humorous illustrations, must have stamped themselves 
un the memory of many. His habit was to choose for his subject some individual thinker (Rousseau, Epicurus, Nietzsche, Wordsworth, were the titles of some of these lectures), or, if he chose a more abstract topic, such as "Duty," he was always careful to attach what he said to some concrete instancethe lecture last referred to taking the unexpected turn of a vivid characterisation of Frederick the Great as a type of devotion to the duties of one's station. Ideas were to Wallace living forces, and unless he could show them in actual operation in concrete instances, he had little hope of making their scope and meaning clear.

In Oxford, Wallace has been known for the last quarter of a century as the brilliant Fellow of Merton,

- and since 1882 as the successor to T. H. Green in the Whyte Professorship of Moral Philosophy. In several respects he was a striking contrast to his predecessor in the chair. They were both markedly original products of modern Oxford. They were both leading representatives of the Idealistic philosophy commonly thought to have been made in Germany and imported into this country by Coleridge and Carlyle. But here the resemblance ends. One of the most remarkable traits in Green was the union of theory and practice. Besides being University professor, Green took an active part in municipal politics, and, as is well known, was in a sense the inspirer of Arnold Toynbee and the modern University Settlement movement. Wallace took little interest in practical politics. It was even with difficulty that he could be brought to interest himself in University affairs. Perhaps, like Schopenhauer, he considered that life was an awkward business, and came to the conclusion that it was best 
$\nabla$ employed in reflecting upon it. But it is more likely and more in harmony with the strong ethical bent of his character that he considered thinking a sufficient employment for any single life. His view in this may have been that of Hegel, who when reproached by his landlady for not attending divine service, replied, "Meine liebe Frau, das Denken ist auch Gottesdienst." Another feature in which Wallace contrasted with Green was the comparative absence in his teaching of any attempt to develop an independent system. He liked to "rove" in philosophy and attaching himself to the thought of another to develop his own by way of exposition and criticism. $\mathrm{He}$ had said of Schopenhauer that his was a philosophy which sought to drag everything to its centre. The opposite might be said of his own; instead of dragging everything to its centre, it moved from centre to centre, and thus sought to extend its circumference further and further. This was partly the result of the strong literary and historical bent of his mind, which makes us sometimes hesitate whether to rank his work as philosophy or literature. In these excursuses his style often reminds one of Carlyle. It was said of Carlyle that he gives us history by lightning flashes. Wallace also has his lightning, but it is the broad and gentle sort we have in summer, lighting up the distance and shedding a peculiar brilliance upon the grey landscapes of philosophy.

Another point in which Wallace contrasted with Green was his dislike of controversy. While one of the most tolerant of men in everyday life, Green used to exhibit a species of almost puritanic antagonism to certain modes of thought, and spent much of his time both in lecture-room and in his books in following the 
errors of the English Sensational and Utilitarian school with remorseless criticism. Wallace, on the other hand, entertained a large toleration for all sorts and conditions of thinkers, and is probably best known for his expositions of doctrines (notably those of Epicurus and Schopenhauer) which stood in direct antagonism to the leading principles of his own philosophy. He complains himself of the injustice we are apt to do to a philosophy by giving it a bad name, on the ground of some isolated feature or doctrine. "It has been the misfortune of philosophers to be known to the philosophical world by some conspicuous red rag of their system which first caught the eye of the bull-like leaders of the human herd." Green, of course, cannot be accused of this kind of injustice; but besides the trenchant and for the most part valid criticism, of which Green was the master, there is need of the more sympathetic method in which Wallace has led the way.

But these differences must not be exaggerated. Wallace was a philosopher, and not a politician. His eyes were turned away from temporary changes to the eternities of thought and being. But he was no dreamer. The reality on which his gaze was anxiously bent was the reality that is in life and things, and not any reality beyond them. Philosophy was not so much a special kind of occupation different from those of ordinary life, but just those ordinary occupations thoroughly understood. In the performance of the more practical part of his own duties as professor, no one ever took more trouble. Though he had much of the poet's insight himself, seeming to go directly to his results, he spared no pains in his efforts to lead others to them by paths which they could follow. He had no sympathy with the exclusiveness of genius or culture. 
$\mathrm{He}$ was the most democratic of teachers. He held that the thinker was only a pioneer going before his fellows, and making straight the path in the wilderness of conflicting opinions. "The true possessor," he writes in a fine passage, "of this visionary faculty is only a pioneer, and his duty is to make the way of airy speed, along which his thought shot up to the light, the king's highway for all sorts and conditions of men. The prerogative of genius is not to find out a private way of his own, a special method for élite spirits; but to lead the multitude at the cost perhaps of his own martyrdom and long, solitary waiting in hope, to see that the way of true genius must ultimately be the way of all."

From another side also he held that the philosopher had a practical function to perform, which ranked him with the politician and reformer. The reformer is the man who feels the restraint which some worn-out form or institution-the old clothes of our civilisationimposes upon the free movement of the human spirit, and struggles to be free himself and set others free. The philosopher, too, bears about with him the burden of the old and outworn, and feels the need to find deliverance for himself and others. The difference is that the burden in the case of the reformer is what is practically unbearable, in the case of the philosopher what is mentally unintelligible. As the one feels himself borne down by the weight of custom, heavy as frost and deep almost as life, so the other is borne down by the burden of all this unintelligible world. As the reformer aims at readjusting a nation's habits, so as to make them serve the ends of its spirit, so the philosopher aims at readjusting men's beliefs about the

${ }^{1}$ Schopenhauer, p. 103. 
world they live in, after such a manner that they may feel at home in it. Philosophy has been defined as the home-coming of the soul. But it is a home-coming that has to be fought for and won on the soul's behalf, and it is the thinker's duty so to win it. For the philosopher also is a man, and, as Wallace held, "das heisst ein Kämpfer sein." "Of all philosophy," he tells us, "it may be said that it aims at emancipation, liberation, freedom."

Nor ought it to be supposed that though Wallace has left nothing that could be called a system, his own point of view is a varying one, or he is in any sense an eclectic. It is quite true that his work was mainly that of the expositor and commentator, and if you were to seek for direct expressions of his own views, you would have to be content with a series of asides, which might make a volume of striking obiter dicta, but could hardly be called a philosophy. Yet no one who has understood his exposition of Hegel can fail to recognise the Hegelian in all that he wrote. It is not here and there, but through whole sections of his comment that the reader feels the author's text to be only a thin veil hiding the commentator's own deeply felt convictions. The difference between Green and Wallace is not that the one is a consistent and systematic writer, while the other is not, but that they put a different interpretation upon the part they were called on to perform, and the contribution they severally were able to make in building up the system of thought, which will hereafter be known as Nineteenth Century Idealism. Green, with his sturdy English dislike of German fashions of thought, used to maintain that we must go back to Kant, and that "the whole thing must be done over again." Wallace, with his touch of poetry and a 
profound sympathy with the more transcendental and theological side of German speculation, thought it was better to have a clear understanding of what " the whole thing" is. Perhaps, when properly understood, it would turn out not to be the wire-drawn thing it was commonly supposed to be, nor so wholly alien to common sense. And if this were so, it would save a good deal of trouble to take what had been done by the successors of Kant as a solid contribution to philosophy, and continue the building on the lines which they had laid down.

Professor Wallace's writings as at present published include several smaller and more popular works, his three larger volumes, consisting partly of introductions and comments, partly of translations from Hegel, together with several articles in the Encyclopoedia Britannica, which are, for the most part, condensations of his books. To the first class belongs his Epicureanism, published in 1880 by the Society for Promoting Christian Knowledge. Here the features of the age of Epicurus are sketched in a few masterly strokes. A picture of the Epicurean Brotherhood is drawn, which will give those of the younger generation, who are interested in such things, a somewhat different idea than used to be common of the "stye of Epicurus." Even the dry bones of the old Atomic philosophy are here brought together and live again. These ancient forms of life and doctrine are apt to appear dead and colourless to the modern student. It requires a talent like that of Wallace's to reanimate them with something of the genius of the men who first conceived them, and even to see in them illustrations, perhaps corrections, of more modern ideas. Is it the Oxford professor's love of paradox, or is it his sympathy and 
insight, which lead him to find in the Garden of Epicurus an anticipation of the gentle society of early Christians, who had all things in common, to remark that Epicureanism is, "of course, a great deal more than (modern) utilitarianism," to point out that the modern developments of the molecular theory do not for a moment "rank for philosophical importance with the Atomic doctrine" of Epicurus, and to discover a strong family resemblance between the Epicurean theory of knowledge and the conclusions of the Critique of Pure Reason? His Kant was published in 1882 in Blackwood's Philosophical Classics. For a condensed and luminous statement of Kant's theory of knowledge, Chapters XI. and XII. of this little book are probably unequalled in the great library of books that have been written upon the philosopher of Königsberg. Many things are here admirably stated, none better than the conclusion of the whole matter, which will correct any impression that I may have left with the reader that Wallace glorified Hegel at the expense of Kant:-

"Kant left behind no system, but he threw out suggestions of matchless fertility, and marked out with the instinct of genius the true form of philosophic problems. . . . For those who have learned Kant, many questions have ceased to trouble: many are bright with a light unknown before: and others are at least placed in a fair way for further solution."

His Schopenhauer was the last, and, as became the subject, the most popular of these works, yet, more than any other, it illustrates Wallace's method, and gives scope to his faculty for combining literary biography with philosophical criticism. He gives us a vivid picture of the great pessimist and mystic, 
making us feel (as none could better) the close connection between a man's character and his philosophy. Pectus theologum facit; and this is true of the philosopher as well as the theologian. In Schopenhauer's case it was in great part the tormenting weakness and waywardness of his own heart that sent him for peace and consolation to a doctrine which found the haven of the soul in the crucifixion of all its desires, and of the will to live itself. Referring to the busts that Schopenhauer had set up in his study (a "plaster-ofparis Kant" standing on his desk, and a "bronze Buddha" occupying a higher position still), Wallace writes :-

"His devotions to the victoriously perfect One of the East were not altogether a whim; and if he spoke of the Upanishads in Duperron's translation as his service-book, it meant that his trust was in the Atmân, and his face set towards Nirvana; it indicated that, amidst the acerbity, vain-glory, and egotism, his excessive sensitivity led him into, he cherished an inner life in the sanctuary, where he at least craved after the eternal tranquillity of the sage. . . . The gentle smile in the Buddha's face of glorified renunciation was his consolation against his own yet clinging weaknesses." 1

Critics have spoken as though it must have been sadly against the grain with Wallace to give so much time to a writer with whom he can have had so little in common as Schopenhauer. It is certainly true that he had little in common with the Schopenhauer he has so graphically described as the "irritable, petulant, paradoxical creature plagued by a most unconquerable vanity . . . selfish, harsh-mannered, and sordid . . . dead to the sweet ties of domesticity, and deaf to the

1 Schopenhauer, p. 210. 
call of public and national interests; sinking, as the years passed by, into a solitary cave, whence, like the giant in Bunyan's allegory, he raged impotently at the heterodox wayfarer." But there was another Schopenhaver whom Wallace hints at in the above passage, the Schopenhauer who, freed from the weaknesses of the flesh, "draws close to the great heart of life, and tries to see clearly what man's existence and hopes and destiny really are, who recognises the peaceful creations of art as the most adequate representation the sense-world can give of the true inward being of all things, and who holds the best life to be that of one who has pierced through the illusions dividing one conscious individuality from another, into that heart of eternal rest where we are each members one of another, essentially united in the great ocean of Being, in which and by which we alone live. With this Schopenhauer Wallace had all things in common. He cared nothing for the fact that he was a rebel against the great dynasty of the Idealists. Indeed, it was observed that he had a curious sympathy with all the great rebels in life and philosophy, to whom, besides Schopenhauer, belonged Epicurus, Rousseau, Nietzsche. It was not every one who called Hegel Lord who, according to Wallace, would obtain an entrance into the heaven of the philosophers, and of those who did, many would be surprised at the company they were expected to keep.

But the works on which Wallace's reputation will chiefly rest are his three volumes upon Hegel: The Logic of Hegel, Translation (2nd ed., 1892); The Logic of Hegel, Prolegomena (2nd ed., 1894); Hegel's Philosophy of Mind (1894). This is not the place to review them. Taken along with the Master of 
$>$ Balliol's Hegel in Blackwood's series, they are the best possible introduction to the study of Hegel. It was said of the earlier English expositors that if, as some of them claimed, they had discovered the secret of Hegel, they had managed to keep it pretty well. This cannot be said of Wallace. He has made it an open secret, so that he who runs may read. In this he stands midway between the older generation of Hegelian scholars, who wrote somewhat obscurely of the central mysteries of the great idealist, and the younger generation, in whom the study of Hegel is entering upon a new phase, which might be called microscopic. This last development is no doubt in the right direction. Hegel said himself that, "The condemnation which a great man lays upon the world is to force it to explain him"; and this condemnation extends, in the case of a great philosopher, to the minutest details of his system. But a philosophy is of interest to mankind at large according to the light it throws on the great questions of life and destiny, not according to the consistency and exhaustiveness with which it has treated of a particular department. There will, therefore, always be a place for commentators who, like Wallace, remind us that idealist philosophy is more than logic and epistemology, and that at least one of its functions is to attempt an answer to the three great questions, "What can I know? What ought I to do? What may I hope for?"

This intimate connection indeed between philosophy and the great practical interests of life, especially the supreme interest of religion, is the characteristic note of Wallace's teaching. It may be of interest, therefore, to inquire more particularly how these two are 
related to one another in his view. But before doing so, we have to ask how he would have defined religion.

It need not be said that his view as to what the essence of religion is differs widely from what nine out of ten middle-class people in England think it to be. Religion does not consist in holding to some form of creed or confession prescribed by church or synod. "There are," he says, "religions of all sorts, and some of them which are most heard of in the modern world only exist or survive in the shape of a traditional name and venerated creed." Neither does Wallace mean by religion that vague discontent with the limitations of our knowledge which goes by the somewhat plaintive name of Agnosticism :-

"The desire of the moth for the star,

Of the night for the morrow,

The devotion to something afar

From the sphere of our sorrow."

The essence of the Agnostic theory is that the object towards which the soul in its religious moments aspires is an unattainable one. How can we love what we cannot know, and how can we know what does not enter into consciousness? We may indeed be conscious of the existence of an absolute and eternal, and, if we like, we may call this consciousness religion, but it is a consciousness which is wholly unrealisable and untranslatable into anything that is of value either in theory or practice. And this is sufficient to reduce religion to a quite negligeable quantity, a marginal or residual element in life without significance for human endeavour. To this doctrine the whole of Wallace's teaching is diametrically opposed. He did not indeed believe in the value or necessity of attempting to prove the existence of a Personal Super- 
natural God. Belief in such a Being was not, in his view, essential to religion. "Religion," he says, "is not necessarily committed to a definite conception of a supernatural - of a personal power outside the order of Nature." What it is necessarily committed to, and what constitutes the essence of religion, is the assurance that there is a unity or whole in things, in their relations to which, if we could but penetrate to them, we should find their purpose, meaning, or significance. This is the faith which in all ages has sustained the religious soul, and which has found in Robert Browning its most conspicuous modern interpreter. Its general nature is thus defined by Wallace:-

"Religion is a faith and a theory which gives unity to the facts of life, and gives it, not because the unity is in detail proved or detected, but because life and experience in their deepest reality inexorably demand and evince such a unity to the heart. The religion of a time is not its nominal creed, but its dominant conviction of the meaning of reality, the principle which animates all its being and all its striving, the faith it has in the laws of nature and the purpose of life. Dimly or clearly felt and perceived, religion has for its principle (one cannot well say its object), not the unknowable, but the inner unity of life and knowledge, of act and consciousness, a unity which is certified in its every knowledge but is never fully demonstrable by the summation of all its ascertained items."1

If this be the true nature of religion, so far is it from being true that this kind of consciousness is unrealisable and untranslateable into anything of value to human life, that we are here for nothing else than to realise it and translate it into thought and act. Religion, indeed, without works is vain, but why need such a religion as that just described remain without

1 Hegel's Philosophy of Mind, p. xxxvii. 
works? What is all morality but one mode of realising it in works? "Morality," says Wallace, "gives a partial and practical realisation of the ideal of religion." It may be said to be religion in action. Another mode of realising it is art. The artist aims at translating into forms that appeal to us through the senses the meaning that his soul discerns in things. But the final and, according to Hegel, the highest mode of realisation is Philosophy, which aims at translating into terms of thought that which in art, religion, and morality we merely feel.

Here, then, we have the relation of which we are in search. Philosophy, so far from being, as is sometimes supposed, antagonistic to religion, is really only the highest form or phase of it. "Das Denken," as Hegel said, "ist auch Gottesdienst." If the astronomer can say that he "thinks God's thoughts after him," this is true in a special sense of the philosopher who "thinks about thought," and thus endeavours to catch a glimpso of reality on its inner side. As Wallace puts it:-

"Philosophy does but draw the conclusion supplied by the premisses of religion; it supplements and rounds off into coherence the religious implications. . . . Its task-its supreme task, is to explicate religion. But to do so is . . . to show that religion is the truth, the complete reality, of the mind that lived in Art, that founded the state and sought to be dutiful and upright; the truth, the crowning fruit of all scientific knowledge, of all human affections, of all secular consciousness. Its lesson ultimately is, that there is nothing essentially common or unclean; that the holy is not parted off from the true and the good and the beautiful."1

These are high claims, but it ought to be remembered

${ }^{1}$ Hegel's Philosophy of Mind, p. xlvi. 
that the Hegelian is not alone in putting them forward. They are the common inheritance of idealist thinkers, from Plato to Spinoza and from Spinoza to Lotze. Whether they can be justified to the reason is a question we have, of course, a perfect right to ask. But perhaps, after all, the best justification of a doctrine is the life of its professors. Philosophy, like wisdom, of which it is a species, is justified of its children, and in the great line of those who have thus justified her, by living consistently in the region of high thoughts, daring to be himself, and never allowing himself (to use his own words) "to be dismayed from his own unique responsibility," thinking, as has well been said of him, with his whole soul, Wallace undoubtedly will occupy a high place.

But lest the reader should go away with the impression that the philosophy which he professed moves proudly in a rare atmosphere of transcendental thoughts, weaving a dogmatic system about an ultimate reality beyond our experience, let me quote in conclusion some more homely words as to its true sphere. They occur in a passage ${ }^{1}$ where he is expounding, after Hegel, the Greek idea of philosophy, but where, as so often in Wallace, the comment is only a transparent veil for his own thoughts.

"Philosophy, in other words, mistakes its place when it sets itself up as a dogmatic system of life. Its function is to comprehend, and from comprehension to criticise, and through criticising to unify. It has no positive and additional teaching of its own; no addition to the burden of life and experience. And experience it must respect. Its work is to maintain the organic or super-organic interconnection between all the spheres of life and all the forms of

${ }^{1}$ Hegel's Philosophy of Mind, p. exxxviii. 
reality. It has to prevent stagnation and absorption of departments - to keep each in its proper place, but not more than its place, and yet to show how each is not independent of the others. And this is what the philosopher or ancient sage would be. If he is passionless, it is not that he has no passions, but that they no longer perturb and mislead. If his controlling spirit be reason, it is not the reason of the so-called 'rationalist,' but the reason which seeks in patience to comprehend and be at home in a world it at first finds strange. And if he is critical of others, he is still more critical of himself ; critical, however, not for criticism's sake (which is but a poor thing), but because through criticism the faith of reason may be more fully justified. To the last, if he is true to his mission and faithful to his loyalty to reality, he will have the simplicity of the child." 


\section{III.}

\section{ROBERT LOUIS STEVENSON'S PHILOSOPHY OF LIFE.}

THE title of this paper may seem to some not a par1 ticularly hopeful one. Stevenson, the romancist, we all know and rejoice in. Stevenson, the moral philosopher, to say the least of it, does not sound promising. So little are we apt to find of moral theory in the books we love best that we should be sorry to be set to seek even for morals. His best characters have few enough of the copy-book virtues; his worst are as bad as they are made; yet we find something admirable in them all, and Stevenson seems to intend that we should. What an admirable character, for instance, is Alan Breck! Yet to the eye of cauld morality what is he but a brand plucked from the burning-well described by Professor Raleigh as insolent, revengeful, implacable, a condoner of murder, a cattle-lifter, a confirmed gambler, and internally as vain as a peacock? As for John Silver, we all know him for the arch-scoundrel that he is. Yet for once, at least, Silver speaks the words of truth and soberness when in the fable, Persons of the Tale, he steps out of the book for half an hour between the chapters to enjoy a pipe and a chat with the virtuous Smollett. "What I know is this-If there's sich a thing as a author, I'm his favourite character. He does me fathoms 
better'n he does you, fathoms, he does, and he likes doing me. He keeps me on deck mostly all the time, crutches and all! and he leaves you measling in the hold where nobody can't see you, nor wants to, and you may lay to that! If there's a author, by thunder, but he's on my side, and you may lay to it." It is in vain that Smollett protests that the author is on the side of good, and that Silver has to mind his eye, because he is not through the story yet. Silver is right. The author's imagination, and with it the reader's-if not his heart also-is engaged to Silver, and there's an end to it.

This being so, it might seem as though a critic had little to do who goes in search of moral teaching in these bright books, hunting, so to speak, for the owl of philosophy among the seagulls and birds of paradise that circle and float through their pages. But we all know there is another side to Stevenson's work. Stevenson was a Scotsman, and he would have been no true Scotsman had he not been something of a moralist and theologian as well as writer of romance. "You can keep no man long," he writes in his Essay on Burns, "nor Scotchman at all off moral or theological discussion." Besides the Stevenson of Treasure Island, Kidnapped, and the Master of Ballantrae accordingly we have the Stevenson of Virginibus Puerisque, of Men and Books, of Memories and Portraits, of The Fables, and of Lay Morals.

Some critics, indeed, while recognising this side of his literary work, seem to deplore it as ranking him with Montaigne and Pepys rather than with Scott, Victor Hugo, and Nathaniel Hawthorne, his proper kindred. They would therefore fain hustle it out of sight as secondary and subordinate to his true character 
as irresponsible poet and romancer. This, however, has always seemed to the present writer not only to misrepresent the character of the man, but to be a preliminary to misunderstanding the whole scope of his work as an artist. What follows is an attempt to do justice to the moral ideas which are not only his stockin-trade in his essays, but underlie even his lighter studies, while they are the soul and essence of his greatest.

If we were to try to indicate in a word the central feature that distinguishes the poetry and fiction of our own time from that of the earlier part of the century just past, we should find it probably in a certain note of sadness, we might almost say disillusionment, that marks the former. It is not only that we live in a period of religious unsettlement, the old order changing, yielding place to new; but the social revolution that inspired Burns and Shelley, and even stirred the colder blood of Wordsworth at the end of the eighteenth and beginning of the nineteenth century with hopes of a new heaven and a new earth, have ended in settling upon us a form of civilisation which by many, who ought to know, has been judged to be one of the prosiest and most disheartening the world has yet seen. The question whether life is worth living, and if so, what makes it, has been put with a new seriousness of purpose, and the value to their generation of the poet and artist is more and more coming to be measured by the answer to it which they have to give-the force and energy with which they can inspire or reinspire our wills-the courage with which they themselves can keep on "the 
sunny side of doubt," and hearten others to walk there along with them.

Now to judge from one side of Stevenson's work we could hardly guess that there was any such question as this for him; and so acute a critic as $\mathrm{Mr}$. William Archer was so far deceived by it as to publish in the year 1885 a review of his style and thought in which he attacked him as a fair-weather prophet. But we know how far this was from the truth, and in the light of his work as a whole, which unfortunately is now before us, taken along with his recently published "Letters to his Family and Friends," wonder how the mistake could ever have been made. We now know how deeply he had drunk of the spirit of his time, how heavily its problem weighed upon him, and in general at least, with what centralising ideas he sought to lighten it.

The question was not to him (it is not, I suppose, to anyone) whether life in itself, as a merely vegetable process, is worth carrying on. The answer to this (if it is ever seriously put) is that none of us really proposes to give it up. We all intend to live as long as we can, or at least as long as is decent. Stevenson. ( certainly in this respect was no pessimist; but held that ordinary life taken by itself had a balance of happiness, or at least of pleasure. "I should bear false witness," he writes after six months of almost total physical collapse, "if I did not declare life happy." And five years later, when he had left this country for good and was running a race against death in the South Sea Island he had chosen for his home (and, as it turned out, his grave), after telling a friend that he had not known happiness for many a year, he goes on, " but I know pleasure still, and take my life 
all through, look at it fore and back, and upside down -though I would fain change myself-I would not change my circumstances." The question is not whether it is worth while living on as animals, but whether it is worth while trying to live strenuously and truly as men, and if so, why?

To this it is usual to answer, "Well, yes, of course," and when we are pressed for a reason to declare that in the long run "it pays"-philosophers merely differing from ordinary people in making the run a little longer. This was not an answer that was likely to commend itself to Stevenson. "Happiness and goodness," he exclaims, "according to canting moralists, stand in the relation of effect and cause. There never was anything less proved, or less probable; our happiness is never in our own hands. . . . Virtue will not help us, and it is not meant to help us; it is not even its own reward except for the self-centred, and I had almost said the unamiable." And in another passage, addressing a young man who had written for advice on the choice of the artist's profession, he uses words which, although in their immediate context referring to the life of Art, are yet equally applicable to the art of Life: "In the wages of the life, not in the wages of the trade, lies your reward; the work is here the wages." "Men," he says again, "do not want, and I do not think they would accept happiness"-what they live for is something quite different. "Gordon was happy at Khartoum in his worst hours of danger and fatigue, M. Aurelius was happy in the deserted camp, Pepys was pretty happy, and I am pretty happy on the whole."

If not happiness, what, then, is it that inspires men in living? Stevenson answers (and this is the central point of all his teaching) that it is a vision of some- 
thing they hardly acknowledge to themselves - an ideal of life behind and beyond their conscious impulses-something now hidden by insistent passions, now flashing out clear and strong like a revolving light at sea-in one man radiant and far-reaching, in another struggling through a sorely bemisted or distorted medium. Many passages could be quoted. in which he states his belief in this universal instinct towards some "decency of life" with which happiness in any of the commonly recognised forms has little or nothing to do. The best-known is probably that in Pulvis et Umbria:-

"Ah! if I could show you this! If I could show you these men and women, all the world over, in every stage of history, under every abuse of error, under every circumstance of failure, without hope, without help, without thanks, still obscurely fighting the lost fight of virtue, still clinging to some rag of honour, the poor jewel of their souls! . . . Of all earth's meteors, here is the most strange and consoling: that this ennobled lemur, this hair-crowned bubble of the dust, this inheritor of a few years and sorrows, should yet deny himself his rare delights and add to his frequent pains and live for an ideal, however misconceived. Nor can we stop with man ... the browsers, the biters, the barkers, the hairy coats of field and forest, the squirrel in the oak, the thousand-footed creeper in the dust, as they share with us the gift of life, share with us the love of an ideal : strive like us-like us are tempted to grow weary of the struggleto do well; like us receive at times unmerited refreshment, visitings of support, returns of courage, and are condemned like us to be crucified between that double law of the members and the Will."

If it be said that this loyalty to an ideal itself witnesses to a faith-the faith at least that it is possible in some degree to realise it because it is in 
some way of the nature of things-Stevenson admits it. This is clearly the moral of the fable, "Something in it." It is expressed more vigorously still in a letter to Mr. Sidney Colvin: "I believe in the ultimate decency of things, ay, if I woke in hell should still believe it." Not, it will be admitted, a lengthy creed. Short as it is, Stevenson lays little stress on it. Most men, he held, live without ever formulating it themselves, and when they come to die it is not required of them. "Here lies one who meant well, tried a little, failed much," is his own choice of an epitaph. The important thing is not what we consciously believe, nor even what we do, but what we mean and how we mean it. Perhaps after all the manliest life is that which can do without even this poor rag of confession. Such, at least, seems the burden of another of the fables, "Faith, Half Faith, and no Faith at all," where his ideal of a man is neither the priest with his proofs of the existence of God in the works of nature, nor the virtuous person who dispenses with any such, relying on the witness of his soul and on the soul of Odin, that "great is the right, and shall prevail," but the old Rover who has no visible faith at all, but hies cheerily along without one. By their fruits ye shall know them. The news comes that the great God is besieged in heaven and like enough to perish out of it. While Priest and Virtuous Persons hasten to make their peace with the devil, the old Rover only swings his axe the more bravely and sheers off "to die with Odin."

From this central notion, that what is good in life and what each in his heart of hearts desires, is not any wages of life, but courageous utterance of himself in the way appointed him, follow other notions in Stevenson's mind as to the cardinal virtues required of 
a man. We have got out of the way of speaking of our virtues. Perhaps because we are not conspicuous for any that are worth speaking of ; perhaps because we have so many that it would be invidious to make distinctions. All the same, such as we have are the underlying props of all the best things about us. Wherever you dig you come upon them, as in our great high roads you come when you dig a foot or two on the great flags that the Romans laid there before us. And when we have a chance of learning something about them from a man who had them of the right sort himself, and knows what they are and what they can do for us, it may be worth while to stop and listen.

It is common to take one or two as cardinal and typical of all the rest. First in the usual order comes Temperance. The word with us does not hit off the meaning. We are apt to think of total abstinence and of short commons of "cakes and ale." That, as everyone knows, was not the old idea of it. The Greeks, for instance (who knew a thing or two about life, if they did not know much "science"), thought not of abstention in connection with temperance, but of total enjoyment. They called it "whole-mindedness," and they meant by it the power not of starving any innocent taste or desire, but of giving all healthy instincts their place in a full and happy life. It suggested to them not asceticism, but enjoyment-the enjoyment of ourselves as complete human beings. The Middle Ages brought in a different idea. It came to be thought that there was a special merit in asceticism for its own sake, as though pain and self-denial were something good in themselves. We only required to be miserable enough here to have a long banker's account in heaven.

All healthy modern teaching is a protest against this 
idea, and Stevenson's is here the healthiest. It is true that there are some whose circumstances are peculiar, or who have a double dose of original sin in some direction. These, Stevenson held, may be called in for heroic sacrifices. "Pascal laid aside mathematics, Origen doctored his body with a knife; every day someone is thus mortifying his dearest interests and desires, and entering maimed into the kingdom of heaven." But this is not an ideal state of things. Our idea of heaven is not of an asylum for the lame, the halt, and the blind-a kind of glorified hospital for incurables.

"To conclude ascetically," says Stevenson, "is to give up and not to solve the problem. The ascetic and the creeping hog, although they are at different poles, have equally failed in life. The one has sacrificed his crew; the other brings back his seamen in a cock-boat and has lost the ship. I believe there are not many sea-captains who would plume themselves on either result as a success."

It is, of course, a terrible mistake to let the soul drive before every gust of passion, but is no less a mistake merely to lie to with sheets drawn into the wind and catching none of it. The true way of salvation is to set forward, and that as early as we may, in some respectable enterprise, the pursuit of knowledge or skill, success, position if you like, in soldiering, manufacturing, doctoring, teaching, trading - something that because it needs all our powers forces us to husband our resources and turn our back on everything that dissipates them. This, at any rate, is Stevenson's teaching.

"The demand of the soul," he sums up, "is that we shall not pursue broken ends, but great and comprehensive purposes in which soul and body may unite like notes in a 
harmonious chord. The soul demands unity of purpose, not the dismemberment of man; it seeks to roll up all his strength and sweetness, all his passion and wisdom, into one, and makes him a perfect man exulting in perfection."

But temperance is at best only a negative virtuea husbanding of our forces. The positive counterpart, the virtue we require for the effective use of them, is the second of the cardinal virtues - that which the Greeks and Romans called courage, or manlinessthe virtue or excellence which sets us to do and keeps us doing the positive work of the world. The great thing, Stevenson held, was to get people under way. Even good people want the necessary courage for the work required of them. They are so afraid of doing wrong that they are apt to do nothing at all. They are so good in general that they are apt to be good for nothing in particular. Stephenson has no patience with this kind of goodness, and does not mince rnatters. "We are not damned," he tells us, "for doing wrong, but for not doing right." "Acts may be forgiven, but not even God can forgive the hanger-back." "Choose the best if you can, or choose the worst; that which hangs in the wind dangles from a gibbet." In the same key he protests, in "Our Lady of the Snows," against the monastic idea of courage, as he elsewhere protests against the monastic idea of temperance. ${ }^{1}$

1 " $\mathrm{Oh}$ to be up and doing $\mathrm{O}$ !

Unfearing and unshamed to go

In all the uproar and the press

About my human business!

My undissuaded heart I hear

Whisper courage in my ear,

With voiceless calls the ancient earth

Summons me to a daily birth.

Thou, $\mathrm{O}$ my love, ye, $\mathrm{O}$ my friends-

The gist of life, the end of ends- 
One of the conditions of this active, forward-looking virtue is to forget the things that are behind the faults and failures of the past. "It is certain," he says, "that we all think too much of sin," a wholesome heresy which he illustrated in a fable:-

"A man met a lad weeping. 'What do you weep for?' he asked. 'I am weeping for my sins,' said the boy. 'You must have little to do,' said the man. The next day they met again. Once more the lad was weeping. "Why do you weep now ?' asked the man. 'I am weeping because I have nothing to eat,' said the lad. 'I thought it would come to that,' said the man."

If he had little sympathy with the good people who hang fire because they have gone wrong in the past or because they are afraid of going wrong in the future, he has still less to say to the people who are deterred from brave undertakings by the fear of what may happen to themselves. He is always ready with a jibe for this kind of mistaken prudence-for the man who with his own purse or his own wretched skin in his eye never gets further in a moral enterprise than a halfpenny postcard or a walk with an umbrella. $\mathrm{He}$ takes the last-mentioned innocent piece of furniture as the symbol of this kind of self-created impediment to swift, effective action. " $\mathrm{I}$ have not forgotten my umbrella," said the careful man, "but the lightning

To laugh, to love, to live, to die, Do call me by the ear and eye !"

"But ye? O ye who linger still

Here in your fortress on the hill With placid face, with tranquil breath, The unsought volunteers of death, Our cheerful General on high With careless looks may pass you by." 
struck him." I suppose the shortest fable in the language.

Another enemy to the proper sort of courage is the weight with which habit and convention press upon us - the paralysing power that the past exercises over the present-what others are doing over what it is right for us to do.

"Although built of nerves," Stevenson writes, "and set adrift in a stimulating world, men develop a tendency to go bodily asleep and to become engrossed among the reflex and mechanical parts of life, till they lose both the will and the power to look higher considerations in the face. This is ruin, this is the last failure in life; this is temporal damnation, damnation on the spot and without the form of judgement."

It is in this connection that we must take the ceaseless war he raged, both in theory and in his own practice, against the merely customary and conventional, and the contempt he always has ready for the class of people who take it as their guide, the "damp gingerbread puppets," who get no satisfaction out of life themselves, and give none to anyone else. No action (according to this reading) is truly good or manly that does not embody some individual thoughts, or express some individual feeling, that does not bear (in a word) the image and superscription of the man himself.

"To do anything," says Stevenson, "because others do it, and not because the thing is good or kind or honest in its own right, is to resign all moral control and all captaincy upon yourself, and go post-haste to the devil with the greatest number."

If it seemed to the reader that in his eagerness to see people agoing upon action he went near denying any radical distinction between good and evil, you have only to hear him in the present connection. 
What he here requires is that people should rouse themselves to a sense of the significance of conduct, the eternal distinction there is in the nature of things between that which is rightly and that which is wrongly done. The fatal defect (he holds) of current standards is not that they are too conscientious about right and wrong, but that they tend to confound all moral distinctions in a universal drab of social conformity.

"The truth is," he writes, "by the scope of our present teaching, nothing is thought very wrong, and nothing very right, except a few actions which have the disadvantage of being disrespectable-when found out; the more serious part of men inclining to think all things rather wrong, the more jovial to suppose them right enough for practical purposes."

What is most wanted in these days-the one thing needful for every day-is that we bring the same energy and intelligence that we apply to our business and professions, to that most difficult of all businesses - the business of living, and take some individual responsibility to have it managed on the best-known plan. What makes life seem stale and unprofitable to so many, and renders possible to others the question with which we started, whether it is worth living at all, is that they have never taken any trouble to discover what it can be at its best, or to think of it as having any possibilities at all beyond the dull round within which custom and fashion have bound it. To rouse men from the sullen stupor in which most of them live, to awaken them to the things of the soul (which, when rightly looked at, are only the common things of the world about them seen in the fresh light of feeling and imagination), is the greatest work to which 
preacher or poet can be called. If there be any who are beyond such human help, for them nothing remains but some sharp visitation of God, none being too sharp so as it effect the cure and give them back to themselves. ${ }^{1}$

The rest of Stevenson's philosophy of life may be summed up in the two great virtues of Honesty and Kindness. These seem simple enough, and to require little thought to understand their scope; but that is just where we commonly go wrong. We interpret them either far too narrowly or far too widely to be of any real value as finger-posts in the way of life. Thus, to hear some people talk of honesty you would suppose that the chief end of man was to avoid being hanged. If they keep their hands out of their neighbours' pockets, if they pay the wages of the market in solid coin of the realm, if they spend the time that is paid for at the desk, in the workshop, or behind the counter, they have fulfilled all the law and the prophets. This was not Stevenson's view. Honesty he held to be something much more wide-reaching. What it was in detail I do not propose here to discuss, but if you

1 See the poem The Celestial Surgeon.

"If I have faltered more or less

In my great task of happiness ;

If I have moved among my race

And shown no glorious morning face;

If beams from happy human eyes

Have moved me not; if morning skies,

Books, and my food and summer rain

Knocked on my sullen heart in vain,

Lord, Thy most pointed pleasure take,

And stab my spirit broad awake;

Or, Lord, if too obdurate I,

Choose Thou, before that spirit die,

A piercing pain, a killing sin,

And to my dead heart run them in." 
wish to know what interpretation one who was himself the honestest of workers put upon this uncommonest of the virtues, I would refer you to the comparatively unknown essay, Lay Morals, from which I quote only a single sentence as a sample. It is, however, one that Edmund Burke himself might have written:

"You can make no one understand that his bargain is anything more than a bargain, whereas in point of fact it is a link in the policy of mankind, and either a good or an evil to the world."

While his aim is here to extend the scope of what is meant by honesty, in what he says of kindness he seems at times to go in the opposite direction, and be seeking to narrow it down to its simplest and most commonplace manifestations.

"There is an idea abroad among moral people," he writes, " that they should make their neighbours good. One person I have to make good-myself. As for doing good, that is one of the professions that are full."

In other passages he seems to go even further, and to drive this individualistic morality to the verge of paradox.

"A. has as good a right to go to the Devil as we to Glory, and neither knows what he does."

Phrases like these seem out of touch with the enlargement which we rightly seek in these days to give to the ancient virtue of charity when we insist that mere kindness is not enough, but that for the redress of the "world-pain" we require a sterner virtue, bearing a closer resemblance to justice than to charity. Stevenson, we know from his letters, had no lack of sympathy with this extension of the scope of human kindness. His fear was lest in the process of extension 
it might lose something of the sweetness and graciousness, the readiness to consider circumstances and to make allowance, to suffer long and yet be kind-all, in fact, that the Greeks understood by the equitable spirit which is the higher form of justice. For the rest he held that when the question lies between the near and the distant, the duty to kin and the duty to kind, the knowledge and the talent of the vast majority of us fit us better for the former than for the latter. From this point of view, who could desire a better summary of the whole duty of man than the following?

"To be honest, to be kind, to earn a little and spend a little less, to make (upon the whole) a family happier for his presence; to renounce, when that shall be necessary, and not be embittered; to keep a few friends, but that without capitulation. Above all, on the same grim condition, to keep friends with himself. Here is a task for all that a man has of fortitude and delicacy."

For these headings of a moral philosophy I have gone to the Essays and Poems, and especially to Lay Morals, where Stevenson sought to set them out in some connection and system. It remains to ask whether they have any counterpart in his stories of adventure, whether the moralist is traceable in the writer of romance. Not prima facie, as we have seen, a promising task. True, some of the shorter stories are conscious illustrations of moral ideas. The reader will think of the best-known of them, Dr. Jekyll and Mr. Hyde. But there are others, such as Markheim and Will o' the Mill, in which the union of the romantic and the ethical, though less apparent, is far subtler, and more suggestive. Yet these form only a fragment of his work, and with Dr. Jekyll thrown in could be 
put together in a couple of hundred pages. What are we to say of the rest of them? What are we to say of the swearing, fighting, plundering, buccaneering crew which turns up in detachments in all of them, and of the whole round of breathless adventure in which it engages, dear to the heart of man and boy alike for no other reason than that it seems to be narrated for its own sole and simple sake?

Of this, as of all other genuine romances, two things remain to be said-Stevenson himself has said them, or at least one of them, in so many words. First:

Morality is not the pinchbeck affair its advocates would sometimes have us believe. It is not any mere part of life, not even three-fourths of it, not any vulgar fraction whatever, but simply the whole of it. Reckoned in this way, you cannot get it into a catechism or copy-book, nor into any book at all, any more than you can get all the sunshine into a picture or the whole music of the sphere into a sonata. At the best

- the moralising writer (and who that is great is not?) will fail; at the worst, if he is true to life himself, he cannot help getting some in. Now these stories and the characters, that are the soul of them, have a bit of morality, and if Stevenson's ideas about it are true, a good solid bit of their own. The first duty of man, on Stevenson's philosophy, as we have seen, is to be alive, and alive his villains certainly are. They "play the merry game of warre" against all social and moral covenants with such zest, such light-heartedness, that the most puritanic reader is bound to share in their gleeful enormities. They devote themselves to crime with a cheerful strenuousness, a whole-mindedness, a richness of ingenuity, and a singleness of purpose which is positively stimulating to the moral 
sense. Others may suffer from the disillusionment and paralysis of repentance, not they. Their villainy is whole-souled and thorough-going to the last. "Even the lower and lesser villainy of Israel Hands" (to quote again from Professor Raleigh) "breathes out his soul in a creed.

'For thirty years I've sailed the seas and seen good and bad, better and worse, provisions running out, knives going, and what not. Well, now, I tell you I never seen good come of goodness yet. Him as strikes first is my fancy; dead men don't bite, them's my views. Amen, so it be.'"

Something like this was probably in Mr. J. M. Barrie's mind when he found in these romances the incarnate spirit of boyhood tugging at the skirts of the old world and compelling it to come back and play. The boy truly is there making his readers boys together

- with him, not in the Auld Lang Syne of an irresponsible past, but in all the toil and travail of their vexed and complicated lives.

The boy is there, but the poet and artist is there too, who to Stevenson's thinking has a further and more helpful office still. In the direct teaching upon conduct which we have reviewed we found an underlying current of protest against the paralysing force of custom. But the matter does not end here, and Stevenson was as convinced of the deadening and estranging effect of conventional modes of seeing and describing the things about us as of conventional mode of action. He would have agreed with the saying of Heraclitus: "Men are estranged from the word that is most familiar to them: what they daily meet is a stranger to them." To break this fatal power of custom to overspread and ossify the meaning of words and things, he held to be the great mission of 
the poet and artist. It was one to which he set himself with even an excess of self-consciousness. One of his means was by the artistry of language to effect a new intimacy between word and thing. His choice of words and epithets has often been dwelt upon by his critics. To some it has seemed too fastidious, too manifestly careful and deliberate. But surely no pains are too great which are directed to the union of words and things in a living whole, form and matter coalescing in the single substance which is the soul of poetry. Judging of the result, at any rate, Stevenson's method more than justifies itself. Phrases such as these (they could be indefinitely multiplied), "the crouching jumper," "the crystal quiet," "essential daylight clean and colourless," "tumultuary silences," the

- "wallowing stone-lighters," the "cathedral flanching down upon the plain," break on us like morning light renewing our vision of the things which they describe. Professor Raleigh has noticed how his use of a word in a special connection sometimes reacts upon its meaning so as to restore something of the image it originally bore, instancing his use of "tremendous" to describe the effects of a volcanic eruption. But this is only part of the charm; the other and greater part is that his use of language renews the image of the thing itself.

But the gift of romance is more than an aptitude of words touching here and there a feature of the world above us with new light, but leaving its main expanse in darkness. Its peculiar power is to cover what it touches with the shimmer of mystery, and thus bring it into connection with the larger life about it-the buried life beneath it. Here also Stevenson would have agreed with a very different writer. 
"Imagination," says Kant, "as a productive faculty is powerful to create as it were another nature out of the matter which actual nature supplies. By its aid, when ordinary experience becomes commonplace, we frame to ourselves a new world, which, though subjected to laws analogous to those of the natural world, yet is constructed on principles that occupy a higher place in our reason. It is thus that we are delivered from the yoke of association which limits our ordinary use of imagination and are enabled to work up the materials supplied by nature into something that goes entirely beyond nature."

Hence the note of warning which is struck in the Essays against the deadening power of custom and familiarity changes in the stories to a bold appeal to the imagination as the revivifier of man's life and of the world of nature. Stevenson tells us of the ways and works of simple men, their sailorings, their fightings, their treasure-seeking, their love and hatred. In all this he appeals to elemental instincts and scenes to carry us back to a time when the world was young. But he does more. For the doings he describes he sets on a background of the familiar things of our present life. A brick-lined street, a lamp-lit alley, a seaport tavern we pass on the railway, a highland cave, a mountain pass, a lighthouse on the cliff, a villa in the sand are common things enough in our working or our holiday time. Yet round them all Stevenson weaves that great web of romance that sets them in a new relation to one another and to the spirit of man.

But I am straying-somewhat awkwardly, it will probably be thought-into the field of the literary critic. My text is that Stevenson had more of a coherent creed and exercised his art with more consciousness of purpose than the critics have given him credit for. It is enough to have called attention to 
this side of his genius. Yet there is one other passage so striking in itself, and so directly bearing on this contention, that I cannot forbear quoting it in conclusion.

1 The Fable of the Touchstone, with its Platonic distinction between mere sense-knowledge, in which things by division lose their meaning, and the higher imagination in which they come together and find their reality as parts of the whole, is the best allegory of his own conception of the artist's functions. The King's words strike the keynote: "Little reck I of gear and little of power. For we live here among the shadows of things, and the heart is sick of seeing them. But one thing I love, and that is truth; and for one thing I will give my daughter, and that is the trial stone. For in the light of that stone the seeming goes, and the being shows that all things besides are worthless." The artist (Stevenson well knew it) needs the seeming for his clay. Like the elder son in the story, he holds that "at least there must be seeming." But he holds, too, that "plain truth" is no truth; "there must be more than seeming." His own insight (the clear pebble of the fable) is the true touchstone before which seeming deepens into being, as the part merges in the Whole. Is not this what is meant by the quest, and the discovery which the traveller makes: "And he took the pebble and turned its light upon the heavens, and they deepened about him like the pit; and he turned it on the hills, and the hills were cold and rugged, but life ran in their sides, so that his own life bounded; and he turned it on the dust, and he beheld the dust with joy and terror; and he turned it on himself, and kneeled down and prayed." 


\section{IV.}

\section{ABSTRACT AND PRACTICAL ETHICS. ${ }^{1}$}

THIS paper is meant as a reply to a criticism that 1 was recently made in public on the method of the London Ethical Society and kindred organisations. The method in question, so far as I understand it, is to assist practice by popularising, through public lectures and printed papers, the best results of the systematic study of ethics. But now we are told that " these results are 'abstract,' and, as such, irrelevant to the problems which the practical reformer has to face. At a time when the chief duty of the moralist, who is more than a mere student of ethical theories, is to touch the conscience and stimulate to active service in the cause of social justice, it is a species of solemn trifling to invite people to academic discussions upon the nature of the good and kindred topics." In opposition to this view I wish to submit that the method of studying moral and social problems which we here aim at encouraging is not so far removed from everyday life as might at first be supposed, and that the kind of ideas for which we stand, so far from being "abstract" in any sense that is opposed to practice, are the only kind that are really practical.

I shall begin with a definition of our terms. What is meant by "abstract" and "practical" ethics, respectively?

${ }^{1}$ Lecture delivered before the London Ethical Society. Published in The American Journal of Sociology, November, 1896. 
By abstract ethics would usually be meant the theoretic discussion of the nature of human conduct and the elements of human well-being. As an example of such a discussion we might take the controversy that has raged from the beginning among moralists as to whether the end is happiness or perfection. But this definition would not be sufficient to distinguish "abstract" from any other kind of ethics. For all ethics is abstract in this sense. It is a system of thoughts and judgments, and all thoughts are abstract in the sense that they are "of " or "about" an object; they are not the object itself.

But if we look closer we shall see that there is an intelligible sense in which we may speak of an ethics which is abstract and contrast it with an ethics which is not. For while ethics has to do with thoughts or ideas, and all ideas are abstract, yet there are abstractions within abstractions. Among ideas of an object we must recognise a distinction between the idea which is abstract in the sense that it is one-sided and partial and the idea which, by holding together different sides or aspects of the thing, aims at becoming concrete as the object itself is concrete. In the sense first mentioned, thoughts or ideas are by their nature abstract. It is no reproach to them that they are so. In the latter sense of the term abstract it is a radical defect of our thoughts to remain abstract when they might be concrete.

If now with this distinction in mind we ask who is it who thinks abstractly, we may be met by an answer that throws a curious light on the common antithesis between the abstract thinker and the practical man. For we are apt to find that the so-called practical and matter-of-fact people, instead of being 
those who have the firmest hold upon the concrete in the sense above defined, are just the people who are most likely to become the victims of abstractions. People, on the other hand, who are sometimes thought of as idealists and dreamers may be just the people who are most likely to be free of them.

Such, at any rate, was the conclusion at which the philosopher Hegel arrived when in a too-little-known pamphlet he addressed himself to this question. "Who," he asks, "thinks abstractly?" And he answers, "Not the man of culture, far less the philosopher, but the uneducated and the so-called practical man." One of his examples is so vivid and so aptly illustrates what is here meant by an abstract idea that I make no apology for quoting it.

A murderer is being dragged to execution. The multitude see only the criminal in him and follow him with their curses. Some fine ladies remark what a powerful, handsome, interesting man he is. The bystanders are scandalised that anyone should be so lost to propriety as to find good looks in a murderer. A priest who stands by and understands the heart explains that it all comes of the corruption of the upper classes. This illustrates one abstraction. These people see only the murderer in the prisoner. They. take no account of his upbringing, the traits of character he has inherited, the previous harsh sentence for some trivial offence that embittered him against society. But, besides the common-sense practical people among the crowd, there are the idealists and sentimentalists. They see nothing of the murderer in the unhappy man, but only the scapegoat of an unjust society. They shout in his honour and would fain throw bouquets on the cart that carries him. This illus- 
trates the opposite abstraction. These people see only what may be alleged in justification of the individual. The outrage on social institutions escapes them. Finally, there is an old woman from the poor-house who is overheard to say as the sunlight strikes upon the prisoner: "See how sweetly God's gracious sunshine falls upon poor Binder's head!" She means it in allusion to the German proverb that a worthless man does not deserve the sun. That was the multitude's view of Binder. God thought otherwise, and the old woman recognises it. She does not, like the sentimentalist, simply cancel his guilt. On the other hand, she does not see in him merely the accursed murderer. $\mathrm{He}$ is going to pay-perhaps rightly - the last penalty to human law, but in the judgment passed by society upon him, society itself is judged. This is concrete thinking. The different sides or aspects of the event have grown together or coalesced in a higher and a truer view.

What we are called upon to notice in all this is that the "abstract" idea is not the more remote and difficult to reach, but the first view that strikes uswhich is commonly superficial and onesided. Its opposite is the concrete idea, which in turn is not what first occurs to us, but is further away, and is only to be reached by a gift of insight, as in the case of the old woman, or as in the case of most of us by a strenuous effort of comprehensive thought. Employed as descriptions of different species of ethics, we may call that kind abstract which is in such a hurry to be practical that it turns in distaste from the labour of impartial thinking, and is content with seeing human life in a light which may be as narrow and one-sided as you please, so long as it affords justification for 
energetic action. That ethics, on the other hand, is concrete which is determined at all costs to understand before it undertakes and is content to postpone practical results in favour of a clear and comprehensive view of the end that it is sought to attain. It remains to be shown that the latter kind instead of being hostile to practice is really and in the long run the more practical of the two.

But before attempting to show this, let us ask, secondly, in what sense we are to take the word "practical." What is meant by "practical ethics"? The sense that is in the mind of our critic is clear. Practical ethics are ethics which lay down some practical end as a moral duty and exhort to its pursuit. But this overlooks the fact that such ends may be practical in a twofold sense. They may be practical in the sense that they are proposed as aims of conduct. In this sense any idea may be practical. Any idea may be made a motive of action. I have an idea of a world in which everyone is comfortable and happy, and this idea may become practical in being made an end of action. But clearly amongst such ends there will be a difference between those that are really practical and those which are not, between those that we are justified in believing can be realised and those which never can be. However active and enthusiastic a man might be in pursuit of the latter kind, it would require a stretch of language to call him a practical man. The conclusion is that practical ethics in the full sense of the word is not simply the ethics which exhorts to practice, but the ethics which sets before us as worthy ends ideas which are really practical in the sense that they are in harmony with the deeper aspirations of mankind at large, and must 
sooner or later be realised in the actual relations of human society. How are we to describe such ideas in terms of the distinction already drawn? Are they abstract or are they concrete? If the kind we called abstract are the kind that are really practical, then the man who wishes to be practical will do well to suspect the gifts of the ethical society. If, on the other hand, we can succeed in showing that to be practical we must be concrete, we shall have established a presumption in favour of their utility. Let us see.

There is undoubtedly a common prejudice that the ideas that can be realised in practice must be of the kind I have called abstract. We cannot drive six abreast through Temple Bar, and we cannot get everything that we wish. We must cut our coat according to our cloth, and the cloth is never enough for the pattern we should like to cut. It is in the nature of things that we should be content with partial success. Practice is made up of compromises, and blessed is the man who does not expect too much.

Now compromise is a large subject, and I do not propose to enter on it here. It is sufficient to point out that it is one thing to accept the conditions under which our ideal of what is best must be realised, it is another to give up the hope of ever realising it, and settling down contentedly to live from hand to mouth without it. The former is compromise in one sense. The Greeks would have called it practical wisdom. The latter is compromise in another. Modern politicians call it opportunism. The admission that in practical policy we must go a step at a time is therefore in no wise inconsistent with the contention that no noble and lasting work was ever done except under the inspiration of some distant and for the 
present unrealisable idea. And such an ideal, if the work is to be really noble and lasting, must be of the kind for which I am contending: it must be a concrete ideal taking in all the elements of the problem to be solved. Anything else, however feasible at the time it may appear, must turn out in the end to be impracticable. The forces of reality are leagued against it. However favourable to it the circumstances may seem to be, there is no sure footing for it in the actual world. With the concrete idea all this is reversed. Let a man but have hold of such an idea, the whole world may be against him; in the end it will come round to him. As Emerson would have said, he has hitched his chariot to a star. He may seem to fail. He may die without seeing the fruit of his labour. But the idea lives, and he may rest in peace. In such an idea he has the substance of things hoped for, the evidence of things not seen.

History will serve us best in illustration. It exhibits abstractions on a large scale. I take one or two almost at random. Everyone is familiar with the part played in the course of the French Revolution by "abstract ideas." Issuing from the brain of that prince of abstract thinkers, Jean Jacques Rousseau, they controlled the whole movement, and had a splendid chance. Founded on the historical examples of Greece and Rome, preached with all the eloquence of the greatest prose writer of his time, dominating a great national uprising, accepted as the creed of the party that finally triumphed over the storm, here, if anywhere, abstract ideas might be expected to succeed. And yet it might with truth be said that not one of Rousseau's positive proposals succeeded in establishing itself as an actual institution. 
Equally striking is the example of the idea that dominated the succeeding decade-the idea of a French Empire founded on the ruins of national liberty in Europe. Every circumstance seemed to combine to favour its realisation. Yet the whole power of the greatest military genius the world has ever seen was insufficient to establish the Napoleonic abstraction in the face of the forces that concrete reality had at its disposal to oppose it.

These ideas failed because they did not correspond to the actual wants of the time. They were not in the line of actual progress. There was no place for them in the moral order that was then on the point of establishing itself among the nations of Europe.

If, on the other hand, you desire an example of the power of a concrete idea, you may go to Professor Seeley's life of Stein, who was Napoleon's contemporary. From the very first the great Prussian minister was in contact with reality. He had conceived the idea of Nationality in all its depth and complexity as the living moral force of the time. He was almost alone among the leading men in Europe in his belief in it. Even to Goethe, with his magnificent humanitarianism, it seemed but a thin abstraction. Everything was against it. The national rising in Spain was a miserable failure. Austria showed no response to it. Russia was cold. Yet Stein stuck doggedly to it, and in the long run, in spite of incredible discouragement and opposition, so far succeeded in organising the national feeling in Prussia as to prepare the way for the fall of Napoleon and lay the foundation of the modern German Empire and modern German civilisation.

Whether the evil influence of abstract ideas may not be overruled and in the long run turned to good, 
as it has been asserted that the despotism of Napoleon was turned to good in that it roused the spirit of freedom in the nations of Europe, is another question. To the individual, at any rate, and especially to the individual who thirsts to be practical, it is a poor consolation to recognise that the good has triumphed and the concrete world has got its way in spite of, or even because of, his efforts to oppose it.

These illustrations are from politics. In ethics and - philosophy the autobiography of John Stuart Mill offers an historical illustration. Mill, it will be remembered, was brought up by his father in the straitest sect of the Pleasure Philosophy. He was trained from his youth up to look for all the law and the prophets to the Utilitarian school, especially to its great founder, Jeremy Bentham. Bentham's contribution to ethics (as is well known) was not his theory that happiness is the end, but that the happinessgiving properties of objects and actions may be reduced to scientific measurement and that the art of life consists in the just appreciation of the pleasure value of objects of desire. As a devout Benthamite, Mill sought to perfect himself in this art and to become a kind of professor of it. But the more of an adept he became in this moral arithmetic, the further he seemed to be from the promised happiness. Measuring all objects of pursuit by their capacity to give positive pleasure, the interest in the objects themselves seemed to evaporate and life to become sordid and empty. In one of the most interesting passages in philosophical biography he has described the period of moral depression which supervened upon this discovery, and from which he only finally succeeded in escaping by casting aside the pleasure-calculus as a guide to happiness, and 
throwing himself into the concrete interests of life. $\mathrm{He}$ explained his experience as an instance of what he called the paradox of Hedonism; the paradox, namely, that to obtain happiness you must cease to aim at it as an end, "to get it you must forget it." The explanation sufficed to save the credit of the school among the followers of Mill, but it could not be expected that it would satisfy anyone else. The

$\checkmark$ true explanation, of course, is that pleasure is only one element in well-being, and only by a confusion could be mistaken for the whole of it. The idea that it was the whole was an abstract idea in the sense for which I have contended, and it revealed its abstractness the moment that a consistent attempt was made to apply it to practice, by refusing to work at all.

The bearing of these examples on the present argument is plain. If in order to be practical in the best sense, ideas must be concrete, and if concrete ideas cannot, as a rule, be had without serious intellectual effort, there is at least a presumption in favour of an institution one of whose professed objects is to offer a hand to anyone who is willing to make the effort required.

I have tried to establish a general presumption in favour of the "abstract" study of ethics. But this is not all that may be said: it may be pleaded also that rising out of the special character of the time in which we live there is at present a special need for such a study.

Our age, we are often told, is an age of transition. This means among other things that on many subjects that concern the life and destiny of human beings we no longer stand where we used to. The old maxims and the old authorities that existed to enforce them no 
longer suffice us. New ideas of individual life are opening up to us, new types of character appeal to us. The centre of authority has shifted from the pulpit and confessional to the press.

And what is true of individual is still more obviously true of social life. For a century or more we have ceased to see any special sacredness in established forms of government, or indeed in any of the fixed forms of social or industrial life. Prescription is no defence. Every one of them is called upon to submit itself to the test of reason and experience. By its utility it must stand or fall.

The consequence of all this is that people who are in earnest about individual or public duty are beset by perplexities that did not trouble an earlier generation. They have lost faith in the precedents and authorities to which it would have appealed, with the result that they are thrown upon their own private judgment in many matters that would have been settled for them in another age. Under these circumstances it need hardly be said that there is danger of mistake where formerly there was none. What precisely the danger is and whence it arises is a more difficult question. The answer will bring us to our point. We shall prepare the way for it if we consider for a moment the nature and origin of the forms we are leaving behind us, and the kind of service they performed for our ancestors.

Take first the religious formulæ of the ages of faith. With all their crudity these continue to impress us with the richness and many-sidedness of their contents. And this becomes comprehensible when we remember that these forms obtained their hold upon mankind because they represented many streams of thought 
and aspiration. The theological doctrines we find epitomised in our articles of religion and confessions of faith were the issue of an earnest attempt on the part of their framers to grasp the meaning of life in all its manifold relations. It was only natural, accordingly, that so long as they were acquiesced in in their entirety they should exercise a double influence over human thought. In some respects undoubtedly they were repressive. This is the side of them that is now commonly emphasised. But in another respect they were expansive and in the strictest sense educative. To understand them called for an effort in the believer - too great an effort as we now think, considering the amount of truth that they contained, yet an effort which had its reward in a dignified and comprehensive view of human nature. ${ }^{1}$ Similarly the catechisms professed to expound the whole duty of man and present us with an ideal of character which we must admit was conceived with extraordinary breadth and insight.

What is true of moral and religious formulæ is true also of the older forms of social, industrial, and political organisation. They did not, of course, leave room for wants that are of recent development, but so far as they went they represented in broad outline the organic requirements of human life. In the times when they were generally accepted there was not much danger that essential elements in human nature should fail to have justice done them.

But they are no longer entirely accepted. We have outgrown the forms that have hitherto served us. New

1 This was what led F. D. Maurice into his paradoxical defence of the Thirty-nine Articles as "guiding the student of humanity and divinity into a pathway of truth, and pointing out to him the different forms of truth."-Life, vol. i. p. 524. 
needs have developed. New classes claim to share the provision that was made for the old ones. The younger generation is knocking at the door. Here and there it is ready to pull down the house if admission be refused it. All this lays a new obligation upon those whose special duty it is as leaders of opinion to recognise those new demands and to point out how they are to be satisfied consistently with the maintenance of the conditions of order and progress in human society. Such persons are called to a new task which can only be adequately performed on the basis of a comprehensive review of the elements of the problem, involving nothing short of the attempt to reconstruct in thought the whole scheme of social life, and to justify to the reason forms and institutions that have hitherto rested on instinct or interest. This, it will be admitted, is a hard enough task under any circumstances. But the difficulty is greatly increased under the circumstances of pressing practical need, in which, as we have seen, it has to be attempted.

It is precisely here that the above-mentioned danger comes in. The danger is lest in our haste to formulate the new ethical creeds and the new programmes of political reform we overlook fundamental elements in human nature and ignore organic needs. Expressed in the terms this paper has tried to make familiar, it is lest, overborne by the clamour of those who "know in part and prophesy in part," we betray the charge entrusted to us by our time, and resign the call "to see life steadily and see it whole."

That this danger is not an imaginary one is seen in the conflict of opinion that exists among would-be leaders on many of the most fundamental questions of social life. Many of these illustrate what we mean 
by an abstraction in the field of politics, and may be taken as typical of the leading forms of abstract ideas in general.

First we have those who may be said to be abstract thinkers because they see the whole without seeing the parts. An important species under this class are the people who see the end without seeing the means. As a rule they are people who have a high ideal of what human life may be, but they are apt to have little or no idea of how their ideal is to be realised. The better type of anarchist is an extreme instance here. The anarchist is a man who looks forward to a time when the law of life shall be the law of liberty, when the cumbrous apparatus of law, with its class bias, its blunders, and its incitements to crime, will no longer exist, when no man shall say, "Know the Lord," for all shall know him, and when force and compulsion shall be things of the past. He is an extreme type, but to the same brotherhood belong all those who, confining themselves to less sudden and sweeping changes, set down all our troubles, moral and social, to some single economic abomination or group of abominations. They have the same ideal as the anarchist, it may be, but it is not law and government themselves, but rent, or interest, or profit, or all of them together under the general head of the individual ownership of capital, that is to blame. They are the kind of people who stand as "independent" candidates, and go to make up independent parties. What they may do or become in the future, when they have got into touch with fact, it would be vain to prophesy. In the meantime they strike one often as somewhat impractical, and sometimes as worse. And the reason is that they are often abstract thinkers in 
the sense described. Their ideas are not in touch with reality at any point at which force may be profitably exercised with a view to improving upon it in the direction of their ideal. They have too great a contempt for what actually exists to hold parley with it at any point. "Things are all wrong." The whole established fabric of society is rotten. There is not even a sound plank on which they can stand to begin the task of setting it right, and so they are apt either to fall back into the ranks of the unemployed politician, the writer and agitator, and do nothing at all; or, if they set their hand to what other people are doing, to be an incalculable and unreliable element, the despair of their friends, and the derision of their enemies.

Shakespeare, who knew everything, knew of this type, and the trouble they might be to themselves and others in the pursuit of their ends.

"Fie on't, O fie," says Hamlet, " 'tis an unweeded garden That grows to seed; things rank and gross in nature Possess it merely."

"The time is out of joint; 0 cursed spite That ever I was born to set it right."

A great deal has been written and said about the source of Hamlet's ineffectiveness. Some have attributed it to his "native irresolution," others to a deep-rooted pessimism, others to his so-called madness. In this difference of learned opinion, perhaps I may be permitted to claim him as a case of an abstract thinker of the kind I am speaking of. He has noble views of things in general, but is lamentably out of touch with the particular. It is not that he has been at college too long, and has thought too much. He has really left it too soon, and has thought too little. 
A little thought, like a little knowledge, is a dangerous thing. With Hamlet the consequence is that he halts and hesitates in action, and when he does act seems to abandon himself to the impulse of the moment, and to be the victim of mere caprice. And so, instead of setting anything right, he sets everything wrong.

The moral is that our duty to the world is never to set everything right, for things are never all wrong. If they were it would be a hopeless task to set about improvement in any form. Mr. Punch has made us laugh at the anarchist who appeals to the British policeman when he has got himself into trouble, but the caricature contains the profounder suggestion that it is, after all, to the status quo that the revolutionist must appeal as the foundation for the state of things which he hopes to establish. It is not only that he relies on human nature as it now is-itself the product of the old order-as the root from which the new order is to spring, but he uses present laws and institutions, a free press and public platforms, posts and railways, parliaments and policemen, as the means of propagating the knowledge of it and preparing the way for its acceptance. This criticism is not, of course, meant to justify obstruction or indifference to progress. Though all can never be wrong-the existence of even one faithful soul to recognise it as wrong or to protest against it means that something, at least, is right-yet there is always something wrong somewhere, which each of us probably was born to set right. But the point to notice is that it is always a very definite thing, whether a defect in our own character or a defect in our neighbour's drains. When we examine it, moreover, we shall probably find that it is not something wholly new we are required to do, but something in 
the line of what has been already done, developing and extending to a new case a principle already recognised.

A second type, which is even commoner than the man who sees the whole without seeing the parts, the end without the means, is the man who contrariwise sees the part without seeing the whole.

As an example of this abstraction, we may take the man who sees one thing wrong here, another there, but has no clear idea of what is right as a whole, or of the direction in which progress ought to move. He sees marks of social disease at this point or at that, but has no articulate conception of what social health in the long run means. And so when he sets to work upon a remedy he is apt to be like the doctor who treats the symptoms instead of the disease. As the former type may usually be known by their contempt for law and government, the people I am now speaking of may usually be recognised by their exaggerated faith in the mechanism of parliament. They aim rather at altering the law than at altering the law-giver. Mr. Herbert Spencer is in bad odour with the newer school of philosophical radicals. He has been roundly and, as I think, rightly denounced on account of his abstract and doctrinaire individualism. And yet there is this of truth at the bottom of his denunciation of laws and law-givers, that hasty legislation dealing with isolated evils is not unlikely in suppressing one only to create another. Mr. Spencer draws the conclusion that since we are so likely to do mischief by legislation we had much better cease to legislate altogether. The argument does not, of course, support this conclusion, but it is a forcible reminder of the obligation politicians are under to make sure before they proceed to legislate, that they have as concrete a view as possible of the 
purpose for which a new Act is devised and the circumstances under which it works.

One or two difficulties raised by the above contention remain to be considered. After the example just quoted, it may suggest itself to some that my indictment is, after all, not against these particular extremes of tendency alone, but against all party or sectional action whatsoever. For is not every party and every opinion that has a name at all marked with the same one-sidedness? Do not all the names by which leading schools of moralists and reformers are known conceal such abstractions as we have been speaking of ? Are not one set of abstractions indicated by individualist, conservative, moderate; another by socialist, liberal, progressive? One set by realist, utilitarian, naturalist; another by idealist, mystic, supernaturalist? And if this is so, will it not be safer for us to keep clear of them altogether, and refuse to call ourselves by any of them?

The fact is undoubtedly true. These names strictly taken do conceal abstractions. But it is to be noted that the defect in question attaches not to names of schools of moralists and politicians alone, but to names of any kind. Logic, as we know, divides names into concrete names and abstract names, but the truth is I that all names are abstract. It is of the nature of names to be abstract, for they all indicate only one side or aspect of the thing they denote. If, therefore, we are going to wait till we can find a name which will express everything we are before we consent to call ourselves anything, we shall have to be content to remain nameless. The one-sidedness of a name is in reality no reason why we should refuse to call ourselves by it, if we find ourselves in general sympathy with 
the party which adopts it. It is, on the other hand, a very good reason why we should be on our guard against the one-sidedness of thought which the name suggests. The penalty that attaches to the neglect of this precaution illustrates a peculiar attribute of abstractions which has often been pointed out. I have already said that abstract ideas are impractical ideas. Circumstances are sure to defeat them. But this is not all. It requires to be added that they defeat themselves. For abstractions are a kind of extreme, and like extremes, they tend to meet. It is impossible for me at this stage in my paper to illustrate this property of abstractions with any fulness. I may, however, in passing, refer to a familiar example of it. We shall all admit that there is such a thing as extreme individualism. One of the marks of it is that it is chiefly effective in promoting socialism. The extreme individualist stands in practice and theory by the rights of property in the most exclusive sense. But the effect of this on the general public is merely to undermine the respect for property, on which all the so-called rights must ultimately rest, and so to play into the hands of the socialist. And the same is true in another way of extreme socialism. What is more common than to see ardent socialists advocating, as a cure for starvation-wages, communistic palliatives, which, if widely applied, could only have the effect of weakening the general movement in the direction of better pay, and so playing into the hands of the individualist?

This paper will not have been addressed to an English audience if it has not suggested to some, as a final objection to the contention it urges, that it is after all the merest commonplace. "You are only 
elaborating with a great deal of unnecessary flourish the truism that we must look at both sides of the shield, and consider all questions that come before us from every available point of view. In life and politics, especially, we have to remember that we have to do with all sorts and conditions of men, and with all varieties of taste. We must be prepared, then, for a little of everything-a little realism and a little idealism, a little socialism and a little individualism, a touch of optimism to give dignity, and a touch of pessimism and of the devil to give a relish to our opinions. We are to go a certain way with the advocates of all these doctrines, but 'not too far." " Well, perhaps I do mean partly this, but I mean a good deal more. For it is possible to look at both sides of the shield without seeing them both as sides of the same shield, and it is possible to see many aspects of a question, and to see how people might differ upon it, without seeing how the different aspects complement one another in the whole that is broken up between them. It is this comprehensive view for which I have been putting in a plea. In this view we not only see the various sides, we unite them. In order to do so we must not merely go round and round, we must take our stand at the centre, and this centre, in morals and politics, as I have tried to show, is nothing else than human character itself.

In advocating the importance of taking such a stand with a view to effective practice, I must not, of course, be understood to be requiring that all would-be reformers should leave the platform and the committeeroom and devote themselves to an arduous course of philosophy. In reform, as elsewhere, we must have division of labour, and those who are the best thinkers 
may likely enough be unfitted for effective action. My contention is that if they are, it will be for other reasons than the nature of their ideas, and that those whose profession it is to carry ideas into practice will not be the worse, but in every way the better for possessing themselves by every means in their power of the results of the best thinking on the ends and ideals of human life.

Ethical societies aim, as I understand them, at bringing these results within the reach of busy people, so that he who runs may read. In pursuing this aim they may require to have recourse to propositions of a high degree of generality -if you like, of abstractness. In this respect their teaching will be colourless and forbidding. "Philosophy," says Hegel, "paints her grey in grey," and this is not less true of ethical philosophy than of philosophy in general. But in stating its formulæ, and calling upon thinking people to understand them, ethics is not forsaking reality and losing touch with practice. On the contrary, its most recent formulæ represent the attempt to rise above the half-truths of current reflection, to embrace more of reality, and so by setting man's life in a truer perspective to give it greater significance. So far from its being a matter of indifference to practice with what ideas we approach the problems of individual and social life, it is this that makes all the difference. "Conception," says Walter Pater, "fundamental brainwork, that is what makes all the difference in art." And what is true of fine art in general is, I venture to think, equally true of that finest of all the arts, the art of life. 


\section{V. \\ WHAT IMPERIALISM MEANS. ${ }^{1}$}

MORE than any event in the memory of the present 1 generation-more than the American War of the sixties, more even than the Home Rule proposals of the eighties - the present war has come with a sword into our midst. It has searched the hearts and tried the reins not only of the great political parties of the State, but of more homogeneous groups of politicians, which we have hitherto been accustomed to think of as bound together in "solid simplicity." At first the controversy was chiefly confined to the circumstances out of which the war arose, but as it has gone on it has come more and more to turn upon the meaning and justification of the whole policy that goes by the name of Imperialism. This is as it should be. No question can be conceived which more vitally concerns the future well-being of the nation, and we might say of the world. The sooner, therefore, we can get away from the heated atmosphere of current controversy, and turn to the wider issues that have been brought to the front by it with the sincere desire to understand them, the better for us as a nation. The present article is an attempt to consider, without reference to South African politics, or party politics of any kind, two questions which everyone will admit are fundamental. First, what is the meaning of the thing we

1 Fortnightly Review, August, 1900. 
call Imperialism? and second, what ought to be our attitude towards it?

In trying to find an answer to the former of these questions, the first thing that strikes us is, that Imperialism is not new, but may be said to have come into existence with our empire itself. Sir John Seeley has shown that if we would understand the meaning of English history in the eighteenth and early nineteenth century, we must see it in the light of the great struggle that was going on between the nations of Europe, and especially of the great duel between England and France for the possession of the New World, and with it for a place among the great Powers of the future. The world-wide character of the wars of the period is seen in the places of their battlesArcot, the Heights of Abraham, the Nile, the Ohio. Even the Continental War that goes by the name was not really for the "Spanish Succession," but for succession to the new empire across the seas. Seeley adds, indeed, that during that period we conquered and peopled half the world in a fit of absence of mind. But this is only partly true. The leading men of the time were well aware of what they had done, and of its importance for the English nation. Tory politicians had their own ideas as to the way the new acquisitions should be governed, but they had no doubt at all as to their value. Even Radicals like Dr. Priestley assumed the retention of the colonies as an axiom of their political creed. But in order to understand how the wider outlook had taken possession of the higher mind of the nation in the third quarter of the eighteenth century, we must go to the speeches of the great Whig politician, Edmund Burke. It has never, I think, been sufficiently recognised (partly, perhaps, 
because Burke's most popular biographer is also the biographer of Richard Cobden) that all the greatest of these speeches, that on Present Discontents, on Conciliation with America, and the whole series upon our conduct in India, were inspired by this larger outlook. Through all, Burke has his eye on the new position we occupied among the nations and the new duties it imposed. To him, at least, if to no one else, our dependencies appeared as "the first, the dearest, the most delicate objects of the internal policy of this empire."

While the Imperial sentiment is thus a creation of the eighteenth century, the form it has assumed to-day can only be understood in the light of the phases through which it has passed in the interval-the remarkable eclipse which it underwent in the early part of the present century, and the equally remarkable development that has taken place in our own time. How are we to explain these changes-enthusiasm passing into indifference, and finally into hostility, to the very idea of an empire, and then again developing into a consuming passion?

The first is comparatively easy to understand. Though the leading political authors and writers were perfectly conscious of the new destiny of England as a nation, the people at large remained absent-minded, and still thought of England as an island power, "in a great pond, a swan's nest." This view was further confirmed both by the actual distance that divided her from her colonists, and by the prevailing sentiment with which they were regarded. To Burke, as we have seen, they were the "dearest, the most delicate objects of our policy"; but to the great mass of the people of England they were dissenters and refugees 
who had forsaken home and country in quest of a liberty it had denied to them. In final confirmation of this view there came the logic of fact, "the only kind of reasoning," as Jowett used to say, "that points to the true tendencies of things"; and the separation of the American colonies seemed to set its seal to the well-known epigram of Turgot, that "colonies are like fruits that drop off when they are ripe."

But the significance of the change in the succeeding generation can only be fully understood when taken in connection with the utilitarianism, practical and philosophical, that was its leading characteristic. To the utilitarian in every period colonies have appeared in the light of "commercial assets," whose value to the mother country has consisted in the command they give her of their markets. When, therefore, it was proved by Adam Smith that the monopoly our colonies promised us was no real advantage, there seemed no longer any valid reason why we should trouble ourselves further on their behalf, and Bentham could bring the whole force of his powerful rhetoric to prove that a nation had no interest as it had no right, and indeed no power, to retain them. Let people cease to regard them with "the greedy eye of fiscality," and they would soon cease to regret the loss of them; a view which received a sort of sacramental authority for succeeding Radicals by being embalmed in James Mill's celebrated article upon Colonies, in the Encyclopadia Britannica of the time. It is true that John Stuart Mill, in the next generation, took a wider view, advocating the retention of our colonial empire as a guarantee of peace and free trade, and as likely to strengthen the moral influence in the counsels of Europe of "the power which, of all in existence, best 
understands liberty; and whatever may have been its errors in the past, has attained to more of conscience and moral principle in its dealings with foreigners than any other great nation seems either to conceive as possible or recognise as desirable." But this "imperialist" view was powerless against the rising tide of Manchesterism, which took up and carried to its logical issue the earlier form of the utilitarian doctrine. According to the view that had come to be prevalent in the middle classes in these years, the destiny of England was to become the workshop of the world, its dense city populations compensated for the loss of the beauties of nature and freer forms of life by the cheapness of coal and calico. In such a "calico millennium" there was clearly no place for the luxury of colonies, much less of an Indian Empire. And though the opinions of John Bright, the greatest of this school, have been much misrepresented, there can be no doubt that on the whole he exercised in this respect a narrowing influence on the national imagination, and carried on into our own time, with a growing weight of authority, the ideas accepted as axiomatic by the early Radicals. It would be a mistake, however, to suppose that this indifference was confined to any one school or party. There is a story told of Lord Palmerston, the least provincial of Ministers, that having on one occasion at a Cabinet meeting a difficulty in finding anyone who would take the post of Colonial Secretary, he finally remarked that he supposed he must take it himself, and, turning to Sir Arthur Helps, who was present, asked him to come upstairs after the meeting was over and "show him where these places were." The contrast between this and the present day is 
sufficiently obvious, and brings us to the question of the causes of so remarkable a change.

Many explanations have been offered by speakers and writers in the last few months. A common opinion is, that it was the work of Disraeli; Lord Salisbury attributes it to the Primrose League; Mr. Bernard Shaw to the Fabian Society. But influences such as these, so far as they are connected with it at all, are only flies upon the wheel. They have not made the dust, far less the wheel itself. They are all part of a wider movement which, when we closely regard it, we shall find, I think, to be nothing less than the Spirit of the Century itself now taking bodily shape and meeting us in a new form of national consciousness at the end of it. And if we ask what the burden of this spirit is, and where we are to look for its growing expression, we can best reply by pointing to the great writers who, as the "soul of their age," have best understood it. I can only here indicate one or two great names and passages.

For the first clear note of its meaning we must go, I believe (as for so much that is needful for the true understanding of ourselves), to Goethe. In two wellknown passages he strikes it with startling clearness. The first is at the end of Faust, the second at the end of Wilhelm Meister. In both of these he indicates the spirit of industry, organisation, civilisation, as the hope of mankind. In both he suggests the mission of Europe to carry this beyond the seas and make the world into a home. "Let us hasten," cries Lenardo in the latter, "to the shore of the ocean and convince ourselves what boundless spaces are still lying open to activity. It has been said, and over again said, where 
I am well is my country! But this consolatory saw were better worded, where I am useful is my country."

But the Germany to which Goethe spoke was as yet unprepared for his message. It had a nation to create at home before looking for an empire abroad. England, however, was in a different position, and it was Carlyle's merit to have first caught the note that Goethe had sounded and to have applied it to ourselves. If there is any single name more than another that represents the ideas for which our new imperialism stands, it is Carlyle's. It was the great Empire-builders of the past, the Cromwells and the Fredericks, that attracted his attention as an historian. It is the call of our own lands across the seas to which he gives voice in his political writings.

"This poor nation, painfully dark about said tasks and the way of doing them, means to keep its colonies, nevertheless, as things which somehow or other must have a value, were it better seen into. They are portions of the general earth where the children of Britain now dwell; where the gods have so far sanctioned our endeavour as to say that they have a right to dwell. England will not readily admit that her own children are worth nothing but to be flung out of doors? England, looking on her Colonies, can say, 'Here are lands and seas, spice-lands, corn-lands, timber-lands, overarched by Zodiacs and stars, clasped by many sounding seas; wide spaces of the Maker's building, fit for the cradle yet of mighty Nations and their Sciences and Heroisms. Unspeakable deliverance and new destiny of thousandfold expanded manfulness for all men dawns out of the future here, to me has fallen the godlike task of initiating all that: of me and of $\mathrm{my}$ Colonies, the abstruse future asks: Are you wise enough for so sublime a destiny? Are you too foolish?"1

1 The New Downing Street. 1850. 
But even Carlyle, in England, was as yet a voice crying in the wilderness. Two things were still wanting to give wings to his words-means of communication and a true political connection. But at the very time that Carlyle was writing, the first of these wants was on the point of being supplied; the "organic filaments" of the dispersed English race were beginning to come together. New arteries and nerve systems were beginning to be formed. The first steamer to Australia ran in 1852 , the first cable was opened in 1872, and by 1879 , the date of the cable to South Africa, connection had been established over the whole group. It is perhaps Kipling's happiest stroke to have fixed on "Deep Sea Cables" as the symbol of the unity of the English race.

Political connection has been of slower growth. But already in the thirties the foundation had been laid in Canada of a new form of Federal union, and when, by the British North American Act of 1867, the Dominion of Canada was created on a plan that has since proved completely successful, the problem here also may be said, in principle at least, to have been solved.

It is difficult and, indeed, fallacious to attempt to fix a particular date for the birth of a movement such as that we are discussing, but it cannot be said to have attained any great depth or cohesion till the early eighties. This was the date of the great awakening that followed the death of Gordon. This was also the date of the publication of two books which, more than anything else, brought home to the reading public the new outlook of our country. Seeley's Expansion of England was published in 1883, and Froude's Oceana in 1885. Two things are interesting with respect to these books in connection with the present sketch. 
The colonies are no longer fruits that drop off when they are ripe. Both writers consciously alter the metaphor, preferring that of leaves and branches that nourish while they spread the influence of the tree; or, better still, of the banyan tree, whose branches root themselves in the ground and add support to the parent stem. In the second place the argument from America is turned. America is no longer an argument for separation, but for retention. It has shown how political union may be maintained over an immense territory. It has proved, further, that it may be worth while going to war to maintain it. During the last decade the ideas of these historians have been carried far and wide by the foundation of Imperial Federation and kindred leagues, and by the spread of a new form of literature to which poets, journalists, novelists, civil servants, soldiers, anthropologists, have contributed, making us more familiar with India, Egypt, Africa, and Burmah than with the West of Ireland or the Highlands of Scotland.

I have connected the great movement in the midst of which we find ourselves with the spirit to which Goethe appeals when he summoned Europe to the work of peopling and organising the world, and which Carlyle saw had its readiest instrument in the British nation. The question may still be raised, whether this is not a lying spirit, and whether we are wise in following its guidance. Wisdom is justified of its children. It is justified, too, of its parents. "Our Imperialism," it may be argued, "does not derive much justification from either. It has been begotten in greed and treachery, and in endless, unrecorded slaughter. It has produced, and is likely to produce, an endless progeny of similar horrors. Its opponents 
have included not only the supporters of a pinchbeck utilitarianism, but the greatest men of the century, those who have stood for peace and good-will among men, freedom and justice among peoples. All that has been said makes Imperialism more comprehensible; it does not justify it. Granted that our material and political discoveries have proved to us how our colonies can be held together. They tell us nothing-are quite irrelevant to the problem-of the government of four hundred million human beings of every race by a handful of Europeans. We had no right to undertake this duty. We have no means of performing it. The attempt only plunges us deeper in the crimes of the past; distracts attention from needed home reforms, and presses on the masses of the people with an evergrowing burden of taxation."

Although this view is probably not widely held at the present moment, it seems so reasonable in itself, and has the support of so great names, that it deserves every consideration. I shall state, as shortly as I can, wherein $I$ think it is in error not only from a practical but from an ethical point of view. In the ethics of human affairs there are two questions that require always to be clearly distinguished: How did the circumstances in which we find ourselves arise? and What do these circumstances require of us? With regard to the former, it is irrelevant to ask what with our present knowledge and present standards we should have done. Only to a very limited extent, even in private life, have we chosen the responsibilities of our situation in the light of present standards. They have grown out of actions often thoughtlessly, perhaps imprudently or even wickedly, undertaken. The good man does not think of repudiating them on that 
account. He is, on the contrary, the readier to accept them in all their fulness. $A$ fortiori is a nation tied to its past. To repudiate its responsibilities, to retire from tasks it has undertaken, however thoughtlessly at the time, is the poorest sort of corporate repentance. In the case of an Empire like ours this would be a crime outweighing all we have committed in creating it. The question is not whether we were right in undertaking all it involves, but how best we shall perform it.

In order to answer this question with any profit, the first essential is to have a clear understanding of what the task precisely is. Mistake on this point will be fatal. Yet our ideas on the subject are commonly of the vaguest. We think, indeed, of our Empire as an amalgam of self-governing colonies and dependent or protected states, but we seldom realise the difference in the kind and extent of the responsibility entailed by these different elements. In respect to the first, the problem is mainly political, the discovery, namely, of a system of government which, while extending the Anglo-Saxon form of liberty, will keep the members of the Empire in organic connection with one another. In spite of our recent success in Canada and Australia, it would be rash to suggest that this problem has been finally solved. Ireland at home, and South Africa abroad, are sufficient evidence to the contrary. Yet it is a problem of comparatively limited extent; it is one, moreover, of essentially the same nature as that to the successful solution of which England, from the days of the Heptarchy, has been progressively approximating. 'The other task is of an entirely different kind and of immensely wider extent. It is not political, but 
mainly social and educational. It is concerned not with the government of a few million Europeans in accordance with European traditions, but the reconstruction of the moral, industrial, and political ideas of some four or five hundred millions of souls of every race and religion and at every stage of civilisation except our own. The thought of it might well stagger us, so unprecedented is it in size, so unprecedented in character, so unlike any for which we have as yet shown any national aptitude. I lay stress on all this, not by way of discouragement from the attempt to grapple with it, but to indicate the necessity of bringing the best qualities of our race to bear upon the problem that is before us. The chief requisites are Courage to face and Wisdom to execute our self-imposed task. The importance of realising what these severally involve must be my excuse for dwelling upon them.

1. Let us be quite clear in the first place as to what the courage is of which we are speaking. It is as different as may be from current jingoism. It differs from it not only in the motive that inspires it, but in the temper to which it is allied. Genuine courage, as Aristotle pointed out long ago, differs from counterfeit in the nobility of its object. The courage of which I am now speaking must draw its inspiration from no less an object than the development of human faculty in something like a quarter of the inhabitants of the globe. Rule of some kind, it may be admitted, is a condition of the attainment of this object, trade may be its effect, but neither can be the leading motive of the nation that is courageous in the sense described. It differs from jingoism, further, in its temper. It must be as remote from a rash ex- 
pansionism as from a craven timidity. We can never too often remind ourselves that there is nothing inherently permanent about an Empire such as ours. Its very growth brings its own lesson with it, teaching us that the Empire which we have gained, Portugal, Holland, Spain, France, have lost; none of them, if we are to believe the historians, from any inherent lack of the spirit of enterprise, but the first two because their empires were founded on too narrow a basis-the last two (to quote Sir John Seeley) for no other reason than that "they had too many irons in the fire." The wealth of England is, of course, incomparably greater than any which these states had at command, but it is not inexhaustible. She also has a narrow basis. She also has many irons in the fire. Recent events have shown how her resources in men, in administrative organisation, even in money, may be strained. One element in the Imperial caution which all this suggests is the spirit of Conciliation. The word has fallen into disrepute in these days by reason of its special application, but the thing itself is as necessary as in the days of Burke's great speech. The arguments in favour of it and the objections to the spirit of violence, which is its opposite, are the same as they were then, and can never be too often recalled. Force is a temporary expedient: "A nation is not governed which is perpetually to be conquered." It is uncertain in its operation: "terror is not always the effect of force." It impairs the object it endeavours to preserve: "the thing you fought for is not the thing you recover, but depreciated, sunk, wasted, consumed in the contest." And the spirit of conciliation that is necessary in dealing with dependent peoples is not less necessary in our relations with our neighbours in 
Europe. I do not admit that we hold our Empire by the indulgence of our neighbours, but I am perfectly sure we can never make it a success without their friendship. Here, too, we have much to learn; and there has been nothing more statesmanlike in the recent utterances of politicians than Lord Rosebery's emphasis on the necessity of securing the acquiescence, if not the co-operation, of other nations.

2. The second of the two conditions I have mentioned is, that we should be prepared to bring our best intelligence to bear on the real problem as above defined, in order to arrive at some clear idea as to the principles on which we ought to proceed. In the history of our past dealings with subject races two phases of policy are clearly distinguishable. There was the long period during which we did nothing as a nation either for negro or Indian. Writing of India in 1783, Burke could say, "England has erected no churches, no hospitals, no schools, has built no bridges, made no roads, cut no navigations, dug out no reservoirs. Should we be driven out this day nothing would remain to tell that it had been possessed by anything better than the ourang-outang or the tiger." But in the early part of this century all this was changed. We began to think of the negro as a fellow-Christian; we deliberately adopted the policy of Europeanising India. Much, however, has happened since then, and grave doubts have begun to beset us, not only as to the adequacy (about this there can be no two opinions), but as to the principle of the means we have hitherto employed. As to one part of this mission of civilisation there need, of course, be no hesitation-viz. the spread of European ideas of truth and justice, and again of European science. Justice is justice, and 
science is science, all the world over. The one is the basis of the moral, as the other of the material wellbeing of any people. But to apply European ideas in these departments is one thing, to make European ideas the basis of all that is taught in schools and colleges is another, and it is here that the doubt arises. Are these nations fit for the education we are giving them? have they capacity enough to make it worth our while to give it? Granting that they have the capacity, are we setting about the task of developing it in the right way? The results of recent study of native life go a long way in providing an answer to these two questions, as favourable to our hopes in the one case as it is unfavourable in the other. They go to show; on the one hand, the wealth of human capacity that underlies the most unpromising material, and on the other the almost complete failure of the efforts hitherto employed, whether by missions or governments, to develop it. To take a single passage on the former subject, from one who was a pioneer in scientific methods of study. Speaking of the Gold Coast negro, not (one would have thought) a very hopeful subject, Miss Kingsley wrote:-

"The true negro is, I believe, by far the better man than the Asiatic; he is physically superior, and he is more like an Englishman than the Asiatic; he is a logical, practical man, with feelings that are a credit to him and are particularly strong in the direction of property; he has a way of thinking he has rights, whether he likes to use them or no, and will fight for them when he is driven to it. His make of mind is exceedingly like the make of mind of thousands of Englishmen of the stand-nononsense, Englishman's-house-is-his-castle type. Yet withal a law-abiding man, loving a live lord, holding loudly that 
women should be kept in their place, yet often grievously henpecked by his wives and little better than a slave to his mother, whom he loves with a love he gives to none other."

But while the best evidence thus goes to show that the children of our Empire have all the necessary stuff, it also goes to prove that we have hitherto failed to work it to much profit. Travellers like Mary Kingsley, journalists like G. W. Steevens, students like Sir Alfred Lyall, all give the same account. The more intelligent of the natives divide themselves into two classes-those who are sullenly hostile to European ideas as portending dissolution to their cherished customs, and those who take to them with avidity as likely to pay. Education in the case of the latter class consists of a thin veneer of European ideas sufficient to destroy the beliefs and sentiments that gave the mind a hold on the realities of life, but wholly insufficient to provide it with anything that can take their place. Like the young lady from the Cameroons ${ }^{1}$ Miss Kingsley tells of, they learn everything, but it amounts to nothing. Deep-rooted customs and superstitions as in Africa, ancient philosophical faiths as in India, are being replaced by the cast-off clothing of orthodox European sects, or a superficial acquaintance with European science and its too frequent accompaniment, European materialism.

The mistake, of course, is that in setting about the education of these people we have taken no trouble to

${ }^{1}$ Asked what they had taught at the Mission School where she had been educated, she replied, "Eberyting." Asked what she had learned, she gave the same answer. "Then, of course, you know the answer to a question that has long puzzled me, why you are black," said Miss K. "Oh yaas!" was the answer; "it is because one of my pa's pas saw dem Patriarch Noah wivout his clothes." 
understand the people we are educating. We have not yet taken to heart and applied abroad what we have known for the last half-century at home, that there can be no true education where the ideas we aim at imparting stand in no organic connection with the ideas already there. We have Child Study Associations, based upon this conception of education, and a whole literature of child psychology in England. What is wanted is a Child Study Association on a large scale, of which every civil servant and teacher in India and Africa shall be members, for the sympathetic study of the Children of our Empire. For of all the prophecies to which we can commit ourselves this surely is the least uncertain, that we shall make no headway, nor accomplish anything of any value to our subjects, to ourselves, or to the world without it.

It is here that our main problem lies, for it is just here, as already suggested, that the natural advantages we have hitherto possessed are likely to fail us. So long as it is a question of order, discipline, administration, the Anglo-Saxon combination of patience and pluck, energy and adaptability to circumstances, give us probably an advantage over any other nation. It is when we come to more delicate tasks, such as education and social reconstruction, requiring higher refinements of insight, tact, and sympathy, that our national genius is apt to forsake us. This is, of course, no reason why we should despair of them. It is a reason, however, why we should bring all our intelligence to bear upon the problem of discovering the best that is known as to the right method of proceeding about them, and the most fitting instruments for their accomplishment.

Is all this (end and means alike as so conceived) a 
wicked and vain-glorious dream? Ten or twenty years ago it might well have seemed so. We had then no solid accomplishment to which to point. But this can no longer be said. There is one corner of the world in which results have been achieved, the significance of which can hardly be over-estimated. The case of Egypt has shown what British administration can achieve when it takes its stand on the principle that in foreign as in home policy the good of the subject is the first object of government, when it has the courage to grasp and undertake all that the situation requires for this object, when it is prepared to bring the best intelligence of the nation to bear on the task it has undertaken, and when, without flinching from the policy the circumstances dictate, it uses every opportunity to conciliate the better elements of European opinion. The details of this masterly piece of work are to be found, as everyone knows, in Sir Alfred Milner's England in Egypt, a book which illustrates from every department of administration what Imperialism can be at its best, and what it must be if it would be anything at all. It has, perhaps, least to tell us on what I have ventured to indicate as the central problem of the future, the reconciliation of Western science and culture with Eastern modes of thought. Yet here, also, there is much that is instructive and much that is hopeful in the methods adopted in Egypt. Even in respect to that most difficult of all problems, the reconciliation of science and religion, the narrative is not without a hint as to one, at least, of the directions in which a solution may be sought. A story is told of an English engineer who, in a particularly dry year, saved the crops of thousands of the people of Upper Egypt by his prompt energy and unremitting labour. Their joy was unbounded, and 
nothing would content them, at the subsequent Thanksgiving Celebration that was held in the chief Mosque of the district, but that the Englishman should be present. This was an unheard-of thing, but such was the gratitude of the people that the most deep-rooted superstition was overcome, and the stranger not only was permitted, but compelled, to share in their worship. Religion and science were for once reconciled. And after all, one may ask, why not? For is not the essence both of science and religion, whether in the East or West, the same? The aim and essence of science, both moral and material, is to secure that justice shall be done, and that the forces of nature from the enemy shall become the friend of man. What else than this is the essence also of religion? If we are to believe the Eastern prophet, this too is "to do justice and love mercy." 


\section{VI.}

\section{THE SCIENCE OF POOR-LAW RELIEF. ${ }^{1}$}

THE present age is frequently spoken of as the age 1 of science. In so describing it we usually have in mind the great inventions that have given us our present command over physical nature, and added to the material resources of civilisation the steam engine, the printing press, the electric telegraph. But the application of the scientific method has been not less remarkable in all that concerns social life than in what concerns our material surroundings. One by one the great arts that have to do with the improvement of the conditions of social life and happiness-law, education, government-have been brought under its influence. To this group belongs the important branch of administration represented by this Association. In the century which has just closed-almost within our own memory - the administration of poor relief has been brought within the domain of science, and short as has been its career under the new régime, it can already show results as definitely marked and as important for the happiness of the community as those attained in any other department of human effort. Diminished numbers and cost are not necessarily, of course, a test of improved administration. But, taken along with other

1 Paper read at the meeting of the Poor-Law Officers' Provident Association, held at Birmingham on February 23rd, 1901. 
circumstances, such as improved position of the classes most liable previously to fall into poverty and improved efficiency of the relief agencies, they are a solid and tangible result by which we can measure our progress. Between the years 1750 and 1832 the cost of poor relief rose in England and Wales from 2s. $2 d$. to $9 s$. $9 d$. per head of population (reaching in 1818 13s. 4d.). Between 1832 (the date, we might say, of the great discoveries in our science) and 1899, notwithstanding the incomparable superiority of the present workhouse, infirmary, and school accommodation, it fell to $7 s .2 \frac{1}{4} d$. In numbers the results are even more striking. Going back about as far as the imperfect state of the statistics permit, we find that in 1848-9 the mean number relieved was $1,000,000$; in $1899-1900$ it was about 800,000 . If the number had increased with the population, we should have had not 800,000 , but over $2,000,000$ of a pauper population. These figures are probably familiar to you. Let me take an illustration from the growth of public opinion in these matters, which may not be so familiar. I take it not from the ideas formerly current among uncultivated people, but from the views held by the two most enlightened men of the time. In 1796 William Pitt brought forward a Bill among the chief provisions of which we find that the rates should be used to supplement wages, that the possession of property should not disqualify for receiving relief, and that loans might be made from the rates to the poor for the purchase of a cow! At the same time, the great reformer Jeremy Bentham was excogitating a scheme for a species of prison, on the principle of a private company, to which the State was to farm out its criminals and paupers to the profit of all concerned. No wonder 
the most recent historian of these times speaks of such schemes as "models of misapplied benevolence."

Before addressing myself to the main object of this paper, which is to ask how the fact of the development of this new science affects ourselves and especially the members of this Association, I propose to come to somewhat closer quarters with it and try to indicate what I take to be its central doctrine, together with one or two of the more familiar consequences which flow from it in actual administration. In most sciences we can point to some central truth from which all their teaching radiates. In physics we have the law of gravitation, in biology natural selection, in economics supply and demand. Can we point to any similar truth in the administration of charity? As the answer to this question contains the burden of what I am going to say, I shall try to state it as clearly as I can. It is contained in a phrase which has recently become current coin among students of social structure, and though apt to be misapplied, represents a vital truth. Society, we are told, is an Organism. By this it is meant that a society, like an animal organism, is made up of individual cells. In a healthy society these cells co-operate in maintaining the life of the whole. Each contributes its share and in return receives back from society the nourishment appropriate to its services, and on the whole equivalent to them. This, of course, is an ideal. In no society we know does it wholly correspond to the fact. In all societies some of the cells are irresponsive to the calls the organism makes upon them, either owing to the natural process of decay or from local and temporary causes. The aim of the social physician under these 1 Mr. Leshite StePHEN's English Utilitarians. 
circumstances is to stimulate the health of the organism both as a whole and in the part affected, so that it may absorb what is no longer of use, and, on the other hand, reinstate the cells which are temporarily disabled in their position of normal efficiency, whereby in return for support they may continue to render service to the whole. To this class of physician belong Administrators of Charity. They proceed, so far as they proceed scientifically, on the central assumption that the society on which they operate is a living organism endowed by nature with capacity (socially and industrially) of absorbing to a large degree the cells and tissues which are temporarily diseased - secreting what is no longer capable of active service, reinstating what is. The significance of this assumption is brought clearly out when we compare it with the opposite one, which lay at the root of the whole discarded business, viz. that the cells had to be supported not only independently of services, but in proportion to the extent to which by their own internal expansion (i.e. "according to the number of children") they were able to absorb nutriment supplied at the expense of the whole. In other words, while the power of self-support was denied to the whole, the individuals were treated without regard to their living relation to their environment within it. If ever one scientific hypothesis was proved better than another, the hypothesis on which we have proceeded since the great Poor-Law Reform of 1834 (witness the figures already quoted) has proved itself superior to that which preceded it. Let us see what it involves with respect to the actual administration of charity. I mention one or two familiar points merely to set them in the light of this central assumption- 
the assumption (I repeat it) that society is an organism composed of cells and tissues, each of which lives in its contribution to the life of the whole.

1. It involves that in all relief we seek the good of the whole, and not of the part, or of the part only as a part of the whole. This is what we mean when we say that charity ought to be "disinterested." It must be disinterested in the first place in that it must be administered for the good of the relieved and not the reliever-the receiver and not the giver. This seems to us here axiomatic, but it was not always so. There was a time when it seemed equally axiomatic that charity was the highway to heaven. The giver thought little of the effect on the receiver so long as the gift was duly lodged to his credit by the proper angelic official. There is a statute of Edward VI. which enacts that " the curate should make (according to such talent as God has given him) a godly and brief exhortation moving and exciting to remember the poor." We can imagine the way in which he would exercise this talent.

We have got a long way past this when a bishop can thank God on his death-bed, as Archbishop Whately is said to have done with his last breath, that he had never given to a beggar in his life. Yet, can we claim that we have completely outlived the attitude of mind of those who, as it has been said, give to relieve themselves and not to relieve the poor?

Further, relief must be disinterested in the sense that we must take account of the effect it will have on the social organism as a whole and in the long run. This also seems axiomatic to us. Yet it was one of the chief difficulties which the Poor-Law reformers had to face that there were large classes who profited by the reduction of wages that the old system brought. 
It is this fallacy on which most of the schemes to establish municipal workshops have hitherto foundered. They have sought the benefit of a class at the expense of the whole. Production is for the benefit of the consumer, i.e. of society as a whole, not of the producer. Any scheme that proceeds on the opposite assumption can only succeed in dislocating industry, and in the end doing more harm than good to the class it seeks to benefit. If we have outlived this form of the fallacy in question, we are still apparently in danger of falling into others like it. Only the other day I read that during a strike in a certain district owing to slack trade, it was used as an argument in favour of the extension of outdoor relief that in this way labour would be kept in the district, and the employers benefited.

2. It is implied that scientific relief should be discriminative. Discrimination is, of course, not the invention of our century. So early as the middle of the sixteenth century in England a distinction is drawn between "impotent sick and diseased"-_." the poor in very deed" - and such as are lusty and may be "daily kept in continual labour." But this vital principle had been forgotten in the latter years of last century and the beginning of this, with the results already noticed. Even the great reform carried this discrimination but a little way. It was left to a later generation to carry it further by dividing these two well-known classes into the equally clearly marked subdivisions of those who are not only poor in very deed, but have become poor by their own deed, i.e. through some moral defect, and those who have become poor in spite of their own deeds through miscarriage of fortune. Only recently have we 
arrived at the distinction which one would have thought the most obvious of all-yet how long it takes to discover the obvious!- - between those who, in Mr. Bumble's phrase, have "offended against the Poor Law" in person and those who come under its influence through no fault of their own, but through parental failing or neglect, and have thus become in a special sense the children of the State. Of all discrimination this last surely is the most vital, and seems to open a new and hopeful chapter in the administration of poor relief.

3. A third characteristic of scientific relief is implied in the two I have mentioned, and is necessary before they can be realised. I mean the organisation of agencies. What should we think of attempts to cure diseased parts of the physical organism conducted with the want of system which characterised the old administration? If, for instance, there were no unity in the treatment applied to the different parts, one part being nourished to repletion, another starved to extinction; at one moment high feeding, at the next cauterising and dieting? Or worse still, if at the same time one doctor were applying a stimulant to reinstate the lapsed cell in a condition of healthy reaction, another were doing his best to secure its permanent disablement as a contributor to the common life? Yet something like this was the condition of things in the Dark Ages of Poor-Law administration. If we are beginning slowly to emerge from this administrative chaos we owe it to a large extent to the wisdom and courage of the great pioneers of reform. There is no more interesting chapter in the history of Poor-Law reform than that which tells of the conflict that Chadwick and others waged against 
the prejudices and sophistries of those who opposed as an interference with local liberty the introduction of the great principle of a strong central organisation. One expected resistance in country districts and from those who were uninstructed in the principles of government. But it was not those only who denounced the Bashaws of Somerset House as "dictators," "tyrants," "a revival of the Star Chamber," "concentrated icicles." One of the leaders of the opposition at the time was our own enlightened town, led by its distinguished and learned historian and lawyer, Mr. J. Toulmin Smith. If to-day the necessity of a strong Central Board is generally admitted, and Poor-Law administration, so far as it depends on the Local Government Board, is an example of what intelligence and organisation can do, we owe it to the public spirit and scorn of temporary popularity shown by the special Commissioners and their successors.

Lagging far behind the organisation of public charity, the century just past has seen the beginning of a similar attempt with respect to private charity. The foundation of the Charity Organisation Society in 1869 witnessed to the widespread conviction that only by the systematic application of scientific methods could we hope to cope with the inheritance of poverty which we have received from the past.

Still more belated, but equally hopeful, has been the attempt to discriminate between the sphere of public and that of private charity, by assigning to the one the province of relief of the destitute, to the other that of reinstatement in the ranks of the self-supporting. Nothing strikes the visitor to one of our great workhouses more forcibly than the impossibility of using the machinery of the Poor Law for this purpose. A 
man is there because he has no trade or he has failed in his trade, or been unable to find work in it. We have no organisation for helpfully meeting these contingencies. With all due deference to Mr. Punch's ingenious suggestion to teach him decoration by establishing Schools of Art in our workhouses, you have no means of instructing him in a trade; you cannot improve him in the one he has learned imperfectly; you cannot find him work. So far from doing the last, you are bound by the conditions of the labour test to put a temporary obstacle in the way of his getting it. Private charity is in a different position, and as time goes on it is to be hoped it will more and more organise itself to meet this class of cases. Even although public administration were furnished with appliances for this purpose, it is difficult to see how it could give the requisite care to individual cases which would be necessary to secure success. The Poor Law deals with poverty wholesale. It offers a test which is successful in proportion as it acts mechanically. Private charity deals with poverty in detail. It operates through the most careful investigation, and is successful just in proportion as it is prepared to deal with special and individual cases by special and individual means. And even although this difficulty were got over and the law operating through the Workhouse and the Casual Ward (the Infirmary, of course, is different) were able and willing to take the requisite trouble, it has one fatal disqualification for supplying this kind of help. By its very nature it operates impersonally. But if one truth has been established more indisputably than another in the science of poor relief it is that assistance given impersonally is apt to do more harm than good by acting 
merely as a means of spreading the bacillus of pauperism. The essence of private charity, on the other hand, is that it admits of personal relations being established between helper and helped, and of relief being administered under the "antiseptic spray" of human feeling: kindliness on the one hand, gratitude and the desire to respond to expectation on the other - the best preservatives against its abuse. "The most useful gift to the poor," says Mr. Mackay, in his excellent little book on the State and Charity, "is a sympathetic personal friendship, but it is cant to suppose that this relation can be created instantaneously upon an application of relief made by a stranger to a stranger."

But I am speaking to a body of expert administrators to whom all this is probably far more familiar than it is to me. What I understand you desire me to discuss with you is not the principles upon which the Poor Law is founded, but some of the wider aspects of the problems with which you deal, and especially the bearing of these recent advances in the science of administration on yourselves and your work as an association. I shall try to formulate the main question as it presents itself to me, and occupy the rest of this paper in the attempt to answer it.

Granted the rise of this new science and the importance of applying it to practice, is not this rather a matter for the Central Administration on the one hand and the elected Guardians of the Poor on the other? Just in proportion as these principles become established, does not the duty of the PoorLaw officers become more and more a matter of administration under a cast-iron system of rules, and less and less of initiation? Does it not mean that the 
Poor-Law system is becoming more and more a huge piece of machinery for grinding out results according to an approved pattern; its administrators more and more mere cogs and wheels in its internal structure, efficient just in proportion as they keep their precise places and mechanically respond to the impulses of the great driving engine at the centre?

The answer to such an argument seems to me to be twofold :-

1. I admit that as science advances, all forms of human industry tend more and more to pass under the domain of forms of organisation that have an apparent tendency to reduce the individual worker to a cog or wheel of a mechanism he has no part in controlling. This is so in production, it is so in distribution. It is equally so in education, and it would be a sign of our being behind the time if it were not so in Poor-Law administration. But $I$ also maintain that just in proportion as this is so it becomes possible, as it becomes necessary, for the individual to rescue himself from the enslavement to routine with which he seems to be threatened, by coming to understand the principles that underlie the trade or industry which he practises. Servitude here, as elsewhere, does not consist in being subjected to principles and rules, but in being a blind or unwilling administrator of them. There is an old distinction between servile and liberal occupations-trades and professions. It would seem at first sight as though modern developments were tending to reduce us all to the former type. In reality the very opposite is for the first time made possible. It is possible for the first time (and I hope will become more and more possible) for the artisan while not ceasing to be an artisan to become an artist, 
the engineman while not ceasing to be an engineman to become an engineer, the mechanic while not to be a mechanic to become a mechanician. A new and liberal interest is added to his work when by the advance of science he is able to understand the nature of the material with which he deals, the laws of force or of life and intelligence through which he operates upon it. There is no occupation, from that of the Prime Minister downwards, which is not in part mechanical, and which may not be undertaken in the spirit of the mechanic. There are few, from that of the pen-worker and furniture polisher upwards, which may not by the development of an intelligent interest in the principles involved be transformed into an art or profession. Certainly Poor-Law administration is not one of these. I wish that anything I could here say could convey to those of you who have not thought of it before the value of the opportunity many of you have of thus adding to the interest of your work by attempting to utilise it for the study at first hand of the operation of social forces, such as slackness of employment, displacement of industry, strikes, the advance of education and technical instruction, the effects of our present licensing system, and a hundred other things, on the rightness or wrongness of our dealings with which, whether through legislation or administration, hang important issues for the future of our city and district. What students of social science are crying out for is accurate observations, statistics, experiments in all these departments, and I submit that within the limits set by the law, and, indeed, just by reason of the organisation that the law has made possible, there is room for intelligent co- 
operation with its ends on the part of every individual of its permanent officials.

2. But there is a second and more important consideration. I have spoken of the advance of science in this field under the different heads of discrimination and organisation. But when you consider it you see that we are after all only at the beginning of these things. To us in this room it seems all A B C, yet there is reason to doubt whether the principles we here acknowledge are at all generally recognised by the public who elects the Guardians of the Poor, and supports our State and voluntary charities, or even by the guardians and administrators of these charities themselves. I take only one example, but it is a crucial one-that of outdoor relief. In this department the teaching of experience is as clear as in any department of science with which I am acquainted. There was a time not so long ago when it was possible on a priori grounds to argue that outdoor relief was not only kinder to the poor, but more enlightened as tending to keep the family together by keeping parents out of the workhouse, and cheaper for the ratepayers. On all these heads the leaders of scientific charity have maintained from the outset that the argument was illusory. But, only within the last few years have they been able to point to evidence at all comparable to that of the more exact sciences, that precisely the opposite is the case. The last two points alone, of course, can be treated statistically, but here the evidence is fairly conclusive. It seems to prove that so far from outdoor relief acting as a species of nonconductor, keeping people beyond the reach of the pauper influences, it often serves (to use the metaphor employed by a recent Government Circular) merely as 
"groundbait to attract them within the meshes of the Poor Law."

This truth was clearly recognised by certain Unions throughout the country between the years 1871 and 1897. In London, Whitechapel, Stepney, and St. George's-in-the-East adopted a policy of strict outdoor relief, with the result that while there was a reduction of outdoor relief to the extent of 8,977 recipients, the recipients of indoor relief only increased by 323 . (In the same period the neighbouring Union of St. Olave's increased its outdoor relief by 197, while its indoor paupers increased by 769.) Bradfield similarly showed a simultaneous decrease, indoor falling from 287 to 112 , outdoor from 999 to 118 . The case of Birmingham is interesting. Between 1870 and 1893 outdoor show a decrease from 7,591 to 778 , indoor an increase during the same period from 2,105 to 3,073 , giving a total decrease of 4,700. But these were, taken all in all, only isolated instances-points of light in surrounding gloom-and if the light that was in them has since gone out in darkness, how great is that darkness! That it has been so is only too obvious from recent statistics. The Local Government Board has published a circular with reference to the present state of the London Unions, which he who runs may read. St. Olave's shows an accelerated downward course. Between 1893 and 1900 its indoor increased 428, its outdoor 1,486, the total expense increasing by $£ 20,557$. Stepney has completely reversed its former policy, exhibiting an increase of 120 outdoor, 325 indoor, with $£ 4,314$ increase in expenditure. These are only typical of what is happening in all the great London Unions. 
Exclusive of salaries, the increase in expenditure since 1894 is $£ 165,282$.

Birmingham statistics show that even in this centre of enlightenment we are in danger of being drawn into the vortex of the present reaction. Since 1894 the total number of recipients has gone steadily up from 4,823 in that year to 5,486 in the last year, the increase being mainly in outdoor poor- $(1894,791$; 1901, 1,236).

Now, I submit that all this witnesses to a widespread indifference both on the part of the general public and of their representatives to the teaching of past experience-an indifference that threatens to undo all the progress that has been made.

But here the objection recurs that this is the concern of the electors and their representative administrators: the permanent officials are powerless in the matter; if we must have popular government, we must pay the price for it, and this is part of it. I do not agree. Democracy has, no doubt, come, and come to stay. And democracy means the extension of the system of government by the elected representatives of the people in what the people think to be its interests. But more and more as the democratic movement extends, we see below the surface another movement going on in the direction of government, not by the public meeting and the platform, but by the permanent official. More and more as organisation proceeds must the spirit in which the law is administered and the details of its administration pass into the hands of the experts. From which it follows that just in proportion as democracy extends it becomes necessary also to extend knowledge and intelligent grasp of principle in the great permanent Services of State. 
No one will persuade me that there is any serious danger of maladministration in any one of them in which there exists a high standard of knowledge and conviction. In Poor-Law relief I look to wide knowledge and settled conviction in the minds of its officials to act as a bulwark in the future against passing waves of popular opinion and as a means of preserving and extending the territory already won from sentimentalism and ignorance. In actual operation this does not involve either an active or a passive resistance to the policy of elected Guardians. Speaking to a leading member of the C.O.S. in London the other day on the subject of the present reaction in London, I asked, "But what can the officer do?" To which he replied, "The whole matter turns on the investigation and report. If the investigation is thorough it is impossible to go wrong." I was reminded of the old philosopher's dictum, "Virtue is knowledge." If we only know sufficient about a case it is difficult to see how it is possible to do wrong.

I have spoken hitherto as though the chief thing were to understand the principles of the Science of Poor Relief as applied to ordinary administration. This, of course, is a great thing. I wish we could think it were more of a fact than it is, but the problems that come before such an Association as this have a wider range. The principles themselves need constant revision and restatement in view of the particular problems of any special time. New developments of organisation are always taking place within the existing machinery. New developments are taking place outside of the Poor-Law system which will have important consequences within it. Of the former class I may quote as an instance the interesting experiment 
that was shown me the other day in the Birmingham Workhouse of a Merit Ward. It seemed a humane and progressive step, yet, as someone said to me about it, "Of course, these things have two sides." Of course they have, and those who understand both sides have here a valuable opportunity of observing the way in which such experiments react on other parts of the system, and so of contributing to the advance of the science of administration generally.

Of outside movements from which it is impossible to keep Poor Law apart I may quote, as a conspicuous instance, the present agitation for the State institution of old-age pensions. I say nothing about its merits here. I merely mention it, to illustrate the range of subjects which those who take the science seriously must endeavour to understand, and to suggest that in the controversy which will inevitably rage over it there is no body of men who have more right to be heard, and, if their opinions are carefully formed in view of all the best knowledge which is to hand, who will have more influence on the ultimate decision of the country than the Poor-Law officials.

I have confined myself in this address to the Science of Poor Relief. I have wished to keep sentiment out. But this is not because I hold that we ought to keep sentiment out of these things. What those who talk about science here want is not that people should not feel about them, but that their feelings should be controlled by their reason. To use an admirable distinction which the infirmary doctor, in Rab and his Friends, draws, we desire that feelings should be motives instead of mere emotions. The things with which you have to do, gentlemen, are mortal-nothing more mortal than the state of the poor who crowd our workhouses, and 
"mortal things touch us." This, at any rate, was the side on which it came home to me the other day as I passed through the wards in the Dudley Road. These, I felt, are people (in the main) who have lost their chance, for whom life is already gone. They exist. They exist under circumstances which, compared with much we see outside, are even comfortable. Yet what they have missed! How apart they seem; how destitute of all that makes life sweet to others at their age or in their condition!

"The little nameless, unremembered acts Of kindness and of love."

And as I left I could not help asking what was the lesson of it all. To many the answer might seem easy : Why, of course, to improve their lot for the rest of their time. I am not going to say that this should not be done. Yet, as my friend said, "There are two sides to it." And is not the true lesson rather to try how we may bring this sort of thing to an end in the fewest number of human generations? how we can so deal with our social problems that as the century goes on fewer and fewer will be reduced to this state of hopeless dependence on a stranger's bounty? This seems an end not unworthy of your enthusiasm, a hope that may sustain men in otherwise sometimes dreary work. But how to further this end? I shall conclude with an illustration and a summary of the answer to which what I have here tried to say seems to point.

There is a well-known principle in the scientific dealing with a problem called indirection-the principle that the shortest road to an end is not always the most direct, that you may effect a purpose by indirect more readily than by direct methods. We were 
all admiring recently Lord Roberts's brilliant application of this method in standing out against the pressure that was brought to bear upon him to march straight to the relief of Ladysmith. He knew of something better than that. By striking at the heart of the country he was able, in a far more effectual way, to bring relief to the beleaguered troops. These things are an allegory. Methods of poor relief which seem to the sentimentalist mere insonsiderate harshness may prove in the end the most merciful and truly charitable.

What, in more detail, does this mean? It means-

1. That we hold fast by the truth we have painfully proved that society as a whole is in a much more hopeful condition than in the ante-reform days was generally assumed-the truth that the body social under normal circumstances is able to support its able-bodied constituents. The poor we have with us, but we have no longer any excuse for believing, as part of the "religion of mercy," that they must always remain with us. Our new creed, on the contrary, is that better education and wiser administration may leave few or none to the public care who are not organically defective and incapable of caring for themselves.

2. It means that we must hold equally fast by the truth that the money and energy saved by stricter administration may with wisdom be directed, meantime at all events, not to saving the rates, but to saving the children. No possible harm, but every good, will be done by unstinted effort to provide the children of the State with the best possible start in life, and thus to stop the stream of pauperism at its source.

3. We must accept the teaching that except in the important case just mentioned the Poor Law can have 
little to do with positive attempts to keep people out of the workhouse, or to reinstate them in the ranks of the self-supporting. For these services we must rely in the main upon voluntary agencies. But these, if they are to accomplish their purpose, must take to heart far more seriously than they have hitherto shown much inclination to do, the call addressed to them alike by common sense and common humanity to educate and organise themselves for this vital service to the country. 


\section{MODERN METHODS OF TEMPERANCE REFORM. ${ }^{1}$}

NO apology is necessary for choosing the subject of 1 Temperance Reform on which to address an audience like the present. Of all single causes of social disorganisation, we should probably agree that intemperance is by far the most outstanding. The expenditure of some $£ 100,000,000$ per annum by the working-classes, and the loss through drink and its attendant dissipations of between thirty to fifty days a year per individual worker, ${ }^{2}$ represent not only an appalling amount of individual poverty and misery, but an economic, political, and (as recent writers have warned us) a military danger to the nation of the first magnitude. Nor do I think I need to apologise for directing your attention to the means of dealing with the problem rather than its pressing importance. There is a passage I seem to remember in the immortal Don Quixote in which the faithful squire, after being soundly belaboured by his enemies, is exhorted by his master to the effect that the reason why he felt that pain all down his back was that the stick which gave it him was of a length to that extent. "God's my life, master," replies Sancho, "as if I could not guess that of my own head! The question is, how to get rid of it." In the same way the question with

${ }^{1}$ Lecture to the Birmingham Temperance Association, January, 1902.

${ }^{2}$ Recent speech by Mr. John Burns, M.P. 
you, I take it, is not of the extent of the evil, but how to get rid of it.

I have therefore chosen the subject of methods rather than the need of temperance reform, and added "modern" because there can be no doubt that during the three-quarters of a century reformers have been at work, and especially during the last ten or fifteen years, circumstances have so altered the state of the problem, that a review of the methods on which reliance has hitherto been mainly placed, and a comparison of them with those which are advocated by progressive writers and speakers in this and kindred fields to-day, seem imperative if we would keep abreast of the times. With this in view, I begin by noting one or two of the most outstanding differences between the spirit and policy of early phases of the movement and the present.

1. In the first place the end aimed at was habitually thought of by early reformers as the total abolition rather than the improvement of the drinking habits of the people-teetotalism rather than temperance. It was, I can remember, a new thing and somewhat scandalising to many of the older societies when the Church of England some years ago started a temperance society on other lines, and summoned to its banner temperate drinkers as well as total abstainers as worthy of association in the great crusade.

2. Following upon this (as we might have expected) the political method which was chiefly relied on was prohibition.

In order fully to realise how natural was the notion that legislation in the interest of reform should take this particular direction, we may pause a moment to 
recall the ideas which permeated the minds and controlled the efforts of political reformers generally in the early and middle period of the nineteenth century. There were chiefly two. In the first place there was the idea which commonly goes by the name of Individualism-the idea that trade and industry, as well as the pursuit of happiness in general, fared best when they were left to individuals with the largest amount of freedom to conduct them in the way which appeared to them best suited to their own advantage. Government and taxes, of course, there must needs be, although the common idea was that the less of them the better. "Society," said a celebrated individualist, "is the outcome of our wants, government of our wickedness," and the saying has had its band of devout believers ever since. The second of the controlling ideas of the time was what we commonly know as Utilitarianism. The word is somewhat vague, and is apt to have a different meaning in public and private life. As a political doctrine of the period we are considering, it meant that the aim of the legislator is the greatest happiness of the greatest number. Combining this with the assumption of individualism (that people were the best judges of what promoted their own individual happiness) it seemed to follow as a corollary that the people in general ought to have the power entrusted to them through a majority vote of controlling their own affairs.

It is not possible to understand the general movement of reform during a great part of the century that is just passed unless we keep these two ideas clearly before us. They are the upper and the nether millstones of the political millers of the time, the 
two forces operating at different angles and explaining the diagonal line which legislative efforts through the whole period tended to take.

Among other things they explain the direction that was actually taken by Temperance Reformers both here and in America. On the one hand, the majority ought to have its way. Should it desire to control the liquor traffic in any State or district, it ought to have the power of doing so. On the other hand, there ought to be in the result the least possible interference on the part of government, whether local or central, with the freedom of the individual. This meant that within the limits of any area, as defined by the majority vote, and subject to such regulations as the bare necessities of public order seemed to require, the trade should be left in the hands of individuals and to the ordinary influences of industrial competition. In other words, it meant prohibition or local option.

Given these two ideas (the two forces of our parallelogram), the direction of the diagonal was clear-it might almost be said to be a mathematical deduction-and a policy was inaugurated which, as you know, dominated the minds of temperance reformers right up to the end of last century, and even to this day constitutes the chief hope of many leading politicians.

3. A third characteristic of the older generation was its faith in direct methods of attack. It might be called the heroic age of temperance as of other social reforms. It had, as we have seen, a certain air of narrowness and doctrinaireness, but combined with this there was a tone of confidence and enthusiasm, a contempt for the forces, whether of human nature, 
social circumstance, or economic institutions which stood in the way of its Utopia, altogether heroic. No evil was so great or so deeply rooted either by nature or by custom as to exclude the hope that it would yield before a direct attack delivered with sufficient energy under the great banner of individual liberty and the popular vote. In hoc signo vinces. Frontal attacks were the order of the day as they were in the corresponding period of the present war. If they met with no success proportionate to their heroism, the reason perhaps was somewhat similar. They were founded on an inadequate estimate of the complexity of the problem-the deep-seatedness of the causes of the evil against which they were directedthe octopus-like character of its branching roots.

Having noted the general attitude of mind with which the last generation faced the problem of intemperance, I now turn to one or two of the circumstances which in the opinion of many (myself among them) have so completely changed the situation as to require a corresponding change in the attitude of reformers towards their work.

One of these is the spread of knowledge as to the physical and physiological causes of inebriety among nations and individuals. Science is coming more and more to recognise that the craving for strong drink in its extremer forms is in a large number of cases an inherited disease which, like others of the same class, can only be effectively treated by the isolation and systematic extermination of the morbid stock. On the other hand, the ideal that seems to be pointed to by the history of nations in the past, as best suited to the temperament or habits of the majority of people, is the moderate use rather than total disuse of 
alcohol. Wherever nations or classes have developed from a condition in which intemperance was common to one in which it is a rare exception, as in the South of Europe and in the upper and middle sections of English society, it seems to have been to a large extent because of the discovery or importation of lighter forms of popular alcoholic drinks. ${ }^{1}$

Another of the more general causes of this change of feeling is the parallel advance in social science, bringing home to us the complex character of social causation, and especially the impossibility of treating the question of intemperance apart from the whole problem of the condition of the people-their homes and home surroundings, their social traditions, the conditions of their employment, and above all from the general level of education, and of taste in the matter of recreation and enjoyment. The more comprehensive view of the problem which is thus brought home to us makes it impossible any longer to place the same reliance upon any single line of attack, least of all upon any merely negative and prohibitive policy. And recent writers have done good service to the cause of temperance by insisting upon the necessity of combining constructive with controlling measures.

But by far the most important factor in this change is beyond all question the knowledge that is now for the first time gathered together in authoritative books and reports of the general issue of the older policy. I wish to dwell upon this as the central point of interest at the present moment and of the utmost significance for the temperance reformer.

Two factors here enter decisively into the situation: first, there is the failure of the policy of prohibition,

${ }^{1}$ See especially Dr. Archdall ReID's book on Alcoholism, 1901. 
taken as a whole, to effect its object; secondly, there is the present state of organisation in the trade representing a policy, in part at least, adopted as a measure of defence against the attacks of the older temperance party.

1. We have, for the first time, before us accumulated evidence gathered from all parts of the world, not only of the failure of the older policy to effect its purpose, but of its tendency to bring with it unforeseen effects in contempt for law and the corruption of its officers as demoralising to a people as drunkenness itself. This result is eloquently brought home to us in the introduction to the able and impartial report of the celebrated committee of fifty which recently investigated the action of prohibition in eight of the chief States of the Union. After enumerating a long list of these effects, it concludes :-

"All legislation intended to put restrictions on the liquor traffic, except perhaps the simple tax, is more or less liable to these objections, but the prohibitory legislation is the worst because it stimulates to the utmost the resistance of the liquor dealers and their supporters."

The evidence the report adduces with regard to the particular form of prohibition we here know as Local Option points to a similar conclusion. It not only has not succeeded in its object; by the evasions and chicanery it produces it brings the law into contempt wherever it has been tried. At one place where the selling of drink is forbidden a man opens a pavilion where South Sea pigs and other strange animals are advertised as on exhibition. On entering each sightseer pays twenty-five cents, and has a large choice of intoxicating drinks for his money. It is not sur- 
prising to hear of the development of a widespread interest in natural history in the district concerned.

In another place it is part of the City Ordinances that no saloon shall be established in any building within five hundred feet of the chief public park. Yet there is a licensed dram-shop right in the middle of the park, which the Council has authorised on the ground that a "saloon inside a park is not within five hundred feet of it."

In still another case the bye-laws require that no licence shall be granted unless a majority of the rentpayers in the square or block where the applicant purposes to establish a house signs the demand-a pretty effective obstacle in most places, one would have supposed! Yet an enterprising applicant who failed to secure the requisite number of votes calmly established a beer-house without it, and when after some time he was challenged, opened a private alley at the back, bought up or erected a row of cheap tenements, which he rented at a low rate to persons ready to sign his petition for a licence.

Speaking of this and similar evidence, Rowntree and Sherwell conclude that "Prohibition has not yet touched the question where it presents the gravest difficulty except to fail."

It is, of course, possible to urge against any general inference from these facts that the circumstances in the British Empire are different-the people more law-abiding, the police less open to corruption, and that if once established by a popular vote, prohibition might in this country be relied upon to have quite other effects.

The writers just quoted see no ground to hope that this would be so. Nor is it easy to see how 
any difference of circumstances can alter the radical defects of all such proposals. Of these defects two appear to me insurmountable. One is the instability of the foundations on which prohibition rests. A popular vote is by its nature fickle, and periods of restriction have always tended to be succeeded by violent and disastrous reactions. But the other and more serious is that Local Option (the only form of prohibition that has ever been seriously proposed in this country) does not touch the real root of the evil, viz. private interest in the sale of liquor to be drunk on the premises. As a sign that reform has already done its work and that no public-house is wanted in a given area, Local Option may have its place in the future of temperance propaganda, but as a central plank in any programme for the initiation of reform it has had its day. Its doom was sealed at the election of 1893 , and we may confidently predict that no responsible statesman will ever revive it till the need for temperance reform and with it for prohibition is at an end.

2. This brings me to the second of the two factors I mentioned as having revolutionised the situationthe consolidation of the economic interest that is concerned in the trade. Both for defence against parliamentary interference and for the furtherance of the sale of its goods the trade occupies a position to-day of unprecedented strength.

On the one hand (and confining ourselves to the United Kingdom) we have an interest representing some $£ 300,000,000$ of capital, distributed over thousands of shareholders of every rank in society with tens of thousands of employees, thoroughly roused to a sense of its danger and prepared, in the words of 
the chairman of the Licensed Victuallers' Central Protection Society, "to go all lengths permitted by the law and to make all sacrifices demanded by the occasion." On the other hand, we have the tightened hold over the licensed houses obtained by the great brewers through what is known as the Tied House System. This system is not a new thing. We hear of it so early as 1818. What is new is the phenomenal rapidity of its development, which has resulted in the inclusion within it of some three-quarters of the licensed houses. As to the general effect of this extension there ought to be no mistake. Attempts have been made to prove that it operates on the whole beneficially by increasing responsibility and by enabling suitable men to enter the trade who would otherwise be debarred by want of capital, and that it does not lead to increased drinking. In exceptional cases all this may very well be true. But it cannot be too widely known or too strongly insisted upon that the general effect is precisely in the opposite direction. The evidence published in the Minority Report of Her Majesty's Commission of 1899 leaves no doubt upon this head. It shows that the ease and frequency with which the licensee under this system is turned out makes it difficult to fix the responsibility for offences against the law; that it tempts many to put their savings into this form of tenancy only to ruin them, ${ }^{1}$ and that the general effect of the whole system is to push the trade and sale of liquor to the utmost. The last is only, of course, what we should expect, but it is inductively illustrated by the significant fact that six-day licences are in much

1 How onerous the conditions of the "tie" may be is illustrated by the reply of the tenant who was asked what he was tied for, "I am tied for everything but sawdust." 
less frequent request for tied than for free houses. In Cheshire (chosen by accident for investigation) out of forty-seven houses with a six-day licence only four are tied houses.

Having indicated the general nature and the leading causes of the altered situation in which reformers find themselves, I now turn to the question of the methods most in harmony with it, and most likely therefore to commend themselves to the rising generation. We may take the points already emphasised as crucial in the change in their order.

1. What is the inference from the mass of scientific and historic knowledge we have now before us on the subject of Alcoholism with regard to the methods of the future? We may put aside at once the reply given by one school of writers to this question. In his recent suggestive study Dr. Archdall Reid has contended, on the analogy of other zymotic diseases, that nations are bound to pass through an epoch of drunkenness before they can purchase immunity from the morbid craving which is the cause of it. By a process of natural selection those afflicted with this nervous disorder die out, and the strong survive, inoculated, as it were, against disease. The Anglo-Saxon race is passing through this phase at present-the Italians and the southern nations of Europe now so markedly immune passed through it in classical times. Some nations, by virtue of their religious beliefthose, e.g., who profess the religion of Mahomet-are restrained from indulging their natural propensity. But when their religious belief weakens they will inevitably enter on a phase of disastrous intemperance. The paradoxical conclusion which Dr. Reid 
seeks to establish on the basis of these facts is that "every scheme for temperance reform hitherto enunciated which depends upon the diminution or extinction of the supply of alcohol-total prohibition, Local Option, the Gothenburg system, and all the others is in effect a scheme for the promotion of drunkenness."

This argument would be more convincing if Dr. Reid had not inadvertently given away his case by allowing the restraining power of great moral and religious ideas. In doing so he admits another check of intemperance besides the physiological one. We are not opposed to the isolation-if possible the sterilisation-of recognised alcoholic stocks. But this (if it ever becomes possible on any large scale) is only one side of the problem. Such arguments as the above ignore the twofold object always more or liss recognised by temperance reformers-the creation of a public opinion in favour of drastic dealing with cases of alcoholic incontinence ("we shall cease," says Mr. Wells, with grim humour in his Anticipations, "to give the drunkard cause to describe himself as his own worst enemy") and the removal of the constant suggestion of the intemperate use of alcohol to which the weak are at present exposed. Between these objects there is no incompatibility. Nor is there the slightest reason why temperance reformers and scientific specialists should not work cordially hand in hand in the future as they have done in the past.

A truer inference from the new facts seems to be that the total suppression of the use of alcohol is not a compassable, not perhaps an ultimately desirable end, and that one of the most hopeful methods of attacking 
inebriety is through the supply of lighter and better kinds of drink. "It was a fatal mistake on the part of the so-called temperance movement," reported a Committee of both Houses in the State of Massachusetts in 1875 , "to prohibit the sale of cider and light beer." And the same view is supported by the English historian of Drink. "Beer," says Mr. Samuelson, speaking of Germany, "means sobriety, wine and spirits mean intoxication." $\mathrm{He}$ adds with regard to our own middle class, that it is the increased consumption of light wines to which its improved drinking habits are largely to be attributed.

2. Whatever we say on all this, the inference forced upon us by the second consideration, the recent consolidation of the interests opposed to radical reform, stands beyond a doubt. It is, I believe, that nothing short of the organised action of the community as a whole will avail in the future to check the abuses of the liquor traffic. In saying this I do not wish to be understood as undervaluing attempts (either through agreement, as is being done in Birmingham, or through State action, as Lord Peel proposes) at reduction in the number of licensed houses. I wish merely to point out that when we have done our best in this direction (and I hope we shall not stop short of our best) we shall still find ourselves face to face with a serious problem. We shall still have innumerable houses in our larger cities: each with a larger clientele of customers; each provided with the means as well as the motive to extend its attractions by a still more palatial glare and glitter over an even wider area than at present. How do we propose thereafter to proceed? The more you consider the limits to the extinction policy the more I believe you will be driven to the conclusion that the 
only ultimate means of coping with the problem is by asserting the claim of localities to have the traffic managed in the way best suited to the welfare of the community as a whole.

In the Minority Report already quoted there are many suggestions worth pondering, but the most valuable of them is not, I believe, that which has hitherto excited most interest-the proposal for the reduction of licences, but that for the control of their issue by a body more directly answerable to the ratepayers and indeed largely consisting of representatives of the county or city council. This is entirely in the right direction, though short of what I believe will be found to be ultimately necessary.

For this conclusion we are being gradually prepared by the growth of public opinion. We have outgrown the individualism of last century. It is not so much that we are "all Socialists nowadays" as that no one is an individualist in the sense described at the beginning of this lecture. For the creed "I believe in the ability and in the sacred right of the individual to conduct his affairs in the way best suited to promote his own welfare" we have substituted "I believe in the right of the community to protect itself against private interests, however powerful, which are hostile to its essential well-being." It showed true insight, therefore, into the conditions of future temperance reform, when, in 1879, Mr. Chamberlain brought forward in the House of Commons his well-known resolution empowering town councils of boroughs to acquire compulsorily the existing interests in the retail sale of intoxicating drink, and if they saw fit even to carry on the trade for the convenience of the inhabitants. The proposal was defeated for the moment. But under his 
leadership, let us hope, or if not, then under that of another, it is sure to be revived. It has indeed been said by some-it was even hinted at by Mr. Chamberlain himself in the interesting address he gave at the opening of the new Temperance Hall a few months ago-that the chance of compulsory acquisition had passed owing to the gigantic increase in the value of these estates, and therefore of the purchase price. I confess I never have been able to see the force of this argument. I agree that a price, and a fair price, ought to be paid. But that the value of a property. is increasing by leaps and bounds, and that there is no immediate sign of diminution in the rate of increase, has always struck me as an odd reason why a desiring purchaser should not risk his capital in the investment.

But in view of possible opposition from temperance reformers to further advance in the direction of corporate control or management of the sale of intoxicants, it ought to be remembered that the advocates of this policy are not likely to stop short at a policy of mere restriction and discouragement. That probably is the mistake that has been made in Scandinavia, where the policy of the Samlags and the Bolags has been to convert the public-house into a kind of post office for the sale of spirits instead of a place of public resort and refreshment where bar drinking is discouraged or forbidden. The true line of development is surely in the direction of reinstating the publichouse in the true sense of the word-the divortium of the ancients-the place of rest and recreation, of diversion and reasonable enjoyment. I have already spoken of the tied houses and their actual effects, from which it will be seen that the real significance of their growth is that it represents the final stage in the 
process of which the house of refreshment has been turned, under the system of private competition, into a mere means of disposing of the largest amount of liquor at the largest possible profit. The new policy must reverse this process by relegating the sale of drink pure and simple to the background, and making these places again what they were in intention, and at one time in fact.

I am aware, of course, that the policy here advocated must seem to many to be treason to the cause as they have hitherto conceived it. It is trafficking in the unclean thing, making gain of unrighteousness, throwing temptation in the way of the weak and causing your brother to offend. And to those who still feel in this way, I do not know if there is any very satisfactory answer. To others who are less rigid adherents of the past, it may be worth while pointing out that the charge commonly brought against them of making the public-house attractive is to misunderstand alike the intention and the probable effect of these proposals. The intention is undoubtedly that in most cases the public-house shall be a place where it will be possible to obtain alcoholic drinks; but it is also intended that these should form only a small part of the attraction, as in most continental restaurants. It is because the new Public-house Trust Association is likely to prove a suggestive experiment in this direction, rather than because it offers a final solution of the problem, that it deserves every encouragement from temperance reformers.

3. We here touch upon the third feature of the policy which the new circumstances demand: it must rely to a much greater extent than hitherto upon indirect influences, and include collective efforts to counteract in every possible way the attractions of strong drink. 
I have already mentioned housing and improved conditions of labour. It is hardly necessary in this city and in this hall to dwell upon these. You all realise the truth of the saying that "the wretched dwelling," and we might add the wretched workshop, "is the purveyor of the public-house."

But I wish in conclusion to say one word on the education of the people in the taste for a higher kind of enjoyment, a department in which the possibilities of development are not yet so fully realised as they ought to be and there is much general misunderstanding.

It is apt, for instance, to be regarded as a question that concerns primarily the School Board and the elementary school teacher, who should aim, it is said, more than they do at cultivating the taste for reading, music, and drawing, as well as for healthy outdoor games among the children. Perhaps the schools can do more than they do at present in these directions; but to expect them with their limited time and staff to turn out the children of the poorer classes in crowded city districts with the tastes that only the best of the middle-class children with infinitely better chances acquire, is not (I submit) reasonable. It is like expecting a court suit from a rag of flannel. It is wonderful what the modern school teacher can do with the cloth he has; but it is wofully scrimp, and there seems no immediate prospect of his getting more. But there is another direction in which we may look for assistance in the meantime.

We are told that the town and county councils are going to have secondary education entrusted to them under the new Education Bill. Here is a form of secondary education which is already in their handsthe education which can be conveyed to adult citizens 
through judicious arrangements for rational enjoyment. It is a great opportunity. We have recently had an Industrial Exhibition in Birmingham, which was crowded every evening for ten successive weeks. Nothing struck observant visitors to that exhibition more forcibly than the proof it afforded of the lamentable want of cheap and respectable places of indoor recreation in our city and neighbourhood. If you had gone to Glasgow during the time of the great exhibition a few weeks ago, you would have been struck with the same thing-only more forcibly still. There was there a hundred times the space, but there was also a hundred times the crowd. It was not a crowd of strangers. That was the remarkable thing. It was the citizens of the place itself, not the people from a distance who made the crowd, and who came there evening after evening, not to see what they make themselves or what other people make in their workshops, but to see one another, to hear some good music, to look at some good drawing or colouring, to have a meal or merely a drink and a pipe in pleasanter surroundings than any publichouse can yet supply.

In this field there is no need for further experiment. The experiments have been made. The results are unmistakable. Some municipalities have already begun to apply them. Glasgow among others. It already has a system of great winter gardens. East and West and South in the city ten thousand people listen to municipal concerts every Saturday afternoon which do not cost the ratepayers a penny. The city has just built a magnificent new art gallery, not second to the National Gallery itself. As a result of the recent exhibition a new concert hall and winter garden is 
likely to be added to the municipal resources of enjoyment. More and better results still will follow when the City Council has the courage to attack the problem of the people's refreshment so closely bound up with the people's recreation. Unfortunately in Glasgow there is the same hesitation and even opposition on the part of some temperance reformers as there is elsewhere to a bold and clearly called-for move. It cannot be (can it?) that temperance people are going to become an obstruction to progress in this, one of the most hopeful of all directions. And yet unless they show themselves prepared to put themselves in line with the teaching of experience and the general progress of ideas, there is a real danger.

I have tried to show what readjustments are required if we would escape this danger-appealing to no academic logic, but to the far more trenchant logic of events. The conclusion which these seem to force upon us (to repeat it) is that no programme of reform is likely to be successful in the coming century, or at all to meet the situation which does not

(1) take a broad and tolerant view of the ideal to be aimed at;

(2) which does not include a large measure of collective control, perhaps collective management of the sale of intoxicants;

(3) which does not include such indirect methods as the improvement, on the one hand, of the homes and, on the other, of the public enjoyments of the people.

In no department of public work is it truer that

"New occasions teach new duties, Time makes ancient good uncouth." 


\section{VIII.}

\section{A LIBERAL EDUCATION. ${ }^{1}$}

TN selecting this subject I have been guided by two 1 reasons. I desired in the first place to use this opportunity to speak more particularly to the students of the College; in the second to dwell a little, in view of the new development that is before us, on some of the wider objects for which a University exists. This seems the more desirable in view of the prevalence of narrower ideas, arising, on the one hand, from the pressure that is being constantly brought to bear upon an institution of this kind by the practical needs of a great industrial and commercial centre, and, on the other, from traditional views concerning the scope of University teaching and the subjects with which it may legitimately deal. In one of George Gissing's novels the hero is represented as standing in the Fountain Square of Birmingham and pointing out the Mason College to a friend, to whom he explains that it is a place "where young men are taught a variety of things, including discontent with small incomes." The jibe illustrates sufficiently the suspicion prevalent among the advocates of the older system that the promoters of technical departments harbour sinister designs upon their cherished ideal of education as culture and humane learning.

1 Opening lecture of the last session of the Arts and Science Faculties in Mason University College, transformed into the University of Birmingham in 1900. 
Standing as we here do at the meeting-point between the old and the new, it is of no little importance that we should try to understand the relation that exists between these two objects-that which (with all their defects) has occupied, and rightly occupied, the attention of the great educational organisations of the past, and that which seems likely to occupy, and rightly to occupy, the attention of those who are entrusted with the organisation of higher education in the future. Perhaps the most pressing need of all at the present moment is that we should recognise it as the teaching at once of theory and experience, that there is after all no antagonism between these two great ends-that which we might call the useful and practical and that which we might call the spiritual and ideal. Not only the best theory, but the actual facts that are pressed home to us by the present position of manufacture and commerce in this country point in the same direction. They go to prove that the best technical and practical results are attained on the basis of a broad, liberal education, and further that those studies themselves which serve most directly the material needs of a great community can be so taught_and as a matter of fact are so taught by the best teachers-as to raise the industrial services for which they are a preparation into the rank of liberal professions.

In laying emphasis, then, on what I call a liberal education, I must not be understood to be opposing it to technical, but merely to be endeavouring to point out that if we would make the best of our present splendid educational opportunity, we must clearly grasp the fact that, besides the services a University can perform in improving commerce and manufacture as a means to life, it has an important underlying function 
in relation to our conceptions of the scope and purpose of life itself. It is idle to ask which of these ranks first in importance-they stand to one another as form to matter, or rather as soul to body. Without the means of life our highest ideal must hang idle in the air, without a noble ideal of the use to which we should put them accumulations of the instruments of life are only a deadweight on the civilisation that has produced them.

What I wish to do, then, is to call attention to the function which a University performs in opening the minds of the men and women who come within its influence to new ideals as to the meaning of life, and in enabling them to understand and enjoy the best things which it offer. This ideal of the true function of a liberal education, which we seem to be reaching so laboriously, is, however, really no new thing. Instead, therefore, of bringing it before you in the words of modern educational theory, which can hardly fail to suggest modern educational controversy, I shall bring it before you in the form given to it by its founder, or at any rate its greatest interpreter. In a well-known passage in the Republic Plato gives it to us in the form of an allegory, the beauty of which must be my apology for quoting it.

"After this, I said, imagine the enlightenment, or ignorance of man in a figure. Behold! human beings living in a sort of underground den, which has a mouth open towards the light and reaching all across the den; they have been here from their childhood, and have their legs and necks chained so that they cannot move, and can only see before them; for the chains are arranged in such a manner as to prevent them from turning round their heads. At a distance above and behind them the light of a fire is blazing, and between the fire and the prisoners there is a raised way; and you will see, if you look, a low wall built along the way, like 
the screen which marionette players have before them, over which they show the puppets.

That is a strange image, he said, and they are strange prisoners.

Like ourselves, I replied; and they see only their own shadows, or the shadows of one another, which the fire throws on the opposite wall of the cave?

True, he said; how could they see anything but the shadows if they were never allowed to move their heads?

And of the objects which are being carried in like manner they would only see the shadows?

Yes, he said.

And now look again, and see how they are released and cured of their folly. At first, when any one of them is liberated and compelled suddenly to go up and turn his neck round and walk, and look at the light, he will suffer sharp pains; the glare will distress him, and he will be unable to see the realities of which, in his former state, he had seen the shadows.

And suppose once more, that he is reluctantly dragged up a steep and rugged ascent, and held fast and forced into the presence of the sun himself, do you not think that he will be pained and irritated, and when he approaches the light he will have his eyes dazzled, and will not be able to see any of the realities which are now affirmed to be the truth?

Not all in a moment, he said.

$\mathrm{He}$ will require to get accustomed to the sight of the upper world. And first he will see the shadows best, next the reflections of men and other objects in the water, and next he will gaze upon the objects themselves, and at last he will be able to see the sun, and not mere reflections of him in the water, but he will see him as he is in his own proper place, and not in another, and he will contemplate his nature.

And after this he will reason that the sun is he who gives the seasons and the years, and is the guardian of all 
that is in the visible world, and in a certain way the cause of all things which he and his fellows have been accustomed to behold." 1

The point in this allegory for us here to-night is the conception of the function of education as the opening of our eyes in order that we may be able to see things about us as real living, full of interest and meaning, and not as the vague and shadowy forms they are to the uneducated and the Such an education is liberal not only in the sense that it is primarily directed to something quite other than the material needs of life, it is liberal also in the sense that it liberates us from those delusive appearances and distorted forms-those "idols of the cave," as Bacon called them-begotten of narrowness, whether of home or of school, of class or profession, of nation or locality.

With this general description of the scope of a liberal education before us, what, we may ask, is the College curriculum which best serves the end in view? If we were again to consult Plato we should find in the succeeding passage a complete system of education, beginning with arithmetic and mathematics, passing through all the sciences then known, and ending in metaphysical philosophy. But as he supposes an undergraduate course of some thirty-five or forty years' duration-a truly liberal allowance-his curriculum (however suggestive in itself as a counsel of perfection) is perhaps hardly what we want. It is not so much that art is long as that life is so short. Leaving detail, let us look rather once more at what Plato called the upper world of reality and note what are the main divisions into which it falls.

The first and most obvious of these is what we 1 Republic, vii. 514, Jowett's Translation (condensed). 
commonly call nature, the objects and facts that press in upon us from the world of experience. We are accustomed to limit the term nature to the material world. But this is purely arbitrary, and I wish here to understand by it not only physical facts, but the facts of our mental life as well. That a knowledge of the laws of nature in this sense should be an essential part of a liberal education goes without saying. To us of the present generation the wonder is that it could ever have been doubted. Yet those who are familiar with the educational literature of a quarter of a century ago will remember how fiercely the conflict raged between the claims of so-called humanistic and of scientific studies to form the main part of a liberal education. Looking back on this controversy, it seems especially surprising to us that the advocates of classical education should have opposed the admission of subjects such as physics and astronomy, which the great Greek and Roman educationists would never have dreamt of omitting. Our wonder indeed at the position taken up by those who resisted the claims of science is equalled only by our wonder at the arguments that were sometimes used by those who enforced them. The leading advocate of science in the sixties and seventies was, as you all know, Professor Huxley. The debt which education owes this great teacher and writer has never yet been paid, perhaps never can be paid. Yet in some of his more controversial writings he seems sometimes to lose sight of what none knew better than he is the true end of education. Though the conclusion at which he aimed was undoubtedly the true one, viz. that science must henceforth be regarded as an essential, if not the essential, part of a liberal education, yet in the dust of the conflict he sometimes seemed to lose sight of the 
true reasons for his conclusion. Thus he tends too much, when advocating scientific education, to dwell on the view of Nature as an enemy whom we may hope to outwit by a knowledge of her tactics. In one passage she is an unseen opponent against whom we are pitted at a mortal game of chess. ${ }^{1}$ In another science itself is compared to the cut and thrust of the skilled guardsman and contrasted with the rough club practice of common sense. Those of us, however, who hold that this is not the only, nor even the most suggestive view of the matter may be excused if we ask whether the argument that scientific knowledge is useful to enable us to hold our own against nature is the right one to use when we wish to show that it ought to be a part of a liberal education-defined, as he agrees with us in defining it, as that which has for its object the proper understanding of "the greatness of the world and of man's mind." It is not because nature is an enemy, against whom we must go forth armed at every point, that we claim for natural science a high place among liberal studies. (This is to put it on a level with merely technical discipline or the bare elements of a useful education.) It is because physical facts are a part of that larger world in knowing which we know ourselves. As Plato's prisoners can only know the meaning of the shadows and reflectionsindeed, can only know the sun itself-the symbol in the allegory for all that is good and true in lifethrough the knowledge of existing things, so we can only know the true meaning of the world in which our lot is cast by a wide acquaintance with the methods and results of physical science. "We may admit,"

1 Science and Education. "A Liberal Education and Where to find It," 1868. 
says Professor Henry Sidgwick, with his usual fine balance, "that a knowledge of the processes and results of physical science does not by itself constitute culture; we may admit that an appreciative acquaintance with literature, a grasp of the method as well as the facts of history, is a more important element and should be more prominent in the thoughts of educators, and yet feel that culture without the former element is now shallow and incomplete. Physical science is now so bound up with all the interests of mankind, from the lowest and most material to the loftiest and most profound, it is so engrossing in its infinite detail, so exciting in its progress and promise, so fascinating in the varied beauty of its revelations, that it draws to itself an ever-increasing amount of intellectual energy; so that the intellectual man who has been trained without it must feel at every turn his inability to comprehend thoroughly the present phase of the progress of humanity and his limited sympathy with the thoughts and feelings, labours and aspirations of his fellow-men." 1

But nature does not exhaust the world of reality. Man has scarcely emerged from his first struggle with Nature than he sets himself to imitate and reproduce her. On his rude axe and spear the savage carves the image of the life which he attacks with them. Over the camp fire he chants the story of his day's exploits. And thus there grows up within, and yet in a sense above the old world of nature which he finds a new world-the true New World-the world of art and literature which he creates. I know, of course, that some theorists have held (among them, strange to say, Plato himself) that this world stands to the other as

${ }^{1}$ Essays on a Liberal Education, ii. 
imitation to reality, as fancy to fact, and is accordingly of little value in an education the aim of which is to turn the soul from darkness to light. But we now know that art and poetry are no mere imitation or dead photograph of nature, but the means by which man seeks to express and render visible to sense the inward meaning of the outward fact, and that they thus stand to it as the soul rather than the double to its body, as the meaning rather than the copy to the text.

If this be so, what, we may ask, does our knowledge of fact avail us, - what knowledge of fact is there apart from a knowledge of the best that has been said and thought about it? Without such a knowledge (to borrow one of Professor Huxley's happy similes) our passage through life would be like the passage along a gallery filled with wonderful works of art, nine-tenths of which have their faces turned to the wall.

It might seem unnecessary to press these two sides of education on your attention, so essential do they both seem, were it not that the student of science is lamentably apt to neglect the one, the student of art the other. The latter has probably been the greatest sinner in the past. It is told of a celebrated professor of Latin that soon after the Franco-Prussian War of 1870 a friend told him that he had just returned from Sedan, to which the professor replied, "Have you, indeed? That is very interesting. The first edition of ( Nonius Marcellus" (a fifth-rate Latin author) "was published at Sedan." That is the result of an education of a sort. I should not call it a liberal or humane education. It does not make a man free. It does not open his eyes. It reminds me of what Jowett once 
called "a learned man in the worst sense of the term."

On the other hand, the student of science is apt to overlook the value of a literary training. He does not see the need of it. He does not know that the formation of a high standard of taste and the power of enjoying the best things in literature involve laborious training. We have all heard of the mathematician who, after reading Paradise Lost, asked what it proved; so true is it that one faculty may be developed at the expense of another, and that a man may see with one eye and yet be stone blind with the other. As, therefore, I would urge the study of science on the student of literature, I would urge the study of literature upon the student of science, and that not only for the reasons that Sir Archibald Geikie urged from this platform last year. The reason is not merely that the study of literature is useful to the student of science that he may be able to write books. This, perhaps, is rather a reason why he should not study it. Nor is it to avoid becoming a bore in his own subject. There are bores in literature as well as in science, and I am not sure that a man may not be a bore in both. Perhaps a bore, like a poet, is born, not made. Nor even do I urge it merely as a reserve against times of weariness and as a source of solace and refreshment. I venture to think that it is just because the ardent student of science is apt to think of literature in this way and to postpone it to a time when lighter forms of enjoyment such as a novel or a game at billiards are necessarily more attractive, that it is so apt to drop out of his life altogether. There is a pathetic passage in Darwin's Life and Letters, in which he regrets that he has quite lost the power of enjoying Shakespeare 
or any poetry. All recent psychology points to the inevitable atrophy of mental as well as physical organs which follows upon the neglect to use them. I urge the claims of literature as the reflection of man upon nature, or rather the reflection of nature in man, and therefore as an aid to the understanding of what both man and nature truly are.

So far I have spoken only of science and literature. I have said nothing of philosophy. Do I include it in one or other of these? or is it something separate, and if so, what place has it among liberal studies?

The question has been partly answered in what I have already said. Some of the subjects that come under the general term philosophy, e.g. psychology, are really only a part of science as here defined. But there is one department of philosophy which performs a quite special function in relation to life, and in doing so has, I think, a claim to be considered an essential part of a liberal education in the full sense of the term.

We defined a liberal education as the education which by developing our powers gives us access into a larger and truer world. I have already spoken of two of the ways in which it does so. In the first place, it enables us to understand nature as given to us in our ordinary experience. In the second, it gives us the key to the world of art and literature which man has constructed out of his deeper experience of the meaning of natare. These two correspond generally to the world of knowledge and the world of feeling. Putting it simply, then, we may say that education in science and literature trains us to know and to feel. But life is not all knowing and feeling. More characteristically than either, life consists of doing. Life, says 
Emerson, is not a thought, but a deed. What gives value to each of the other elements is the purpose which they serve. What gives value to knowledge is the end for which it is employed. What gives value to enjoyment in art and literature is the deeper hold it gives us of what is worth doing in life. Poetry, said M. Arnold, is criticism of life. Beside the world of nature, therefore, and the world of art, there is the world of action. Besides knowledge and feeling there is conduct. Conduct, said Arnold, is three-fourths of life. As he did not tell us what the other fourth is, and I have myself never been able to discover, I am inclined to think that it also is conduct. And if this is so, if that in which our interest as men and women ultimately centres is neither art nor nature, but life and conduct, I need not spend time in proving that the study of those ideals of happiness which are the basis of conduct both in individuals and societies ought to have a place in any liberal scheme of education. I have already quoted Professor Huxley as an advocate of scientific education. But there was no more ardent believer than he in the necessity of a philosophic basis for our culture. In the address which he delivered at the opening of this College, speaking of the condition of prosperity in this great community, he urged the need there was of "a clear understanding of the condition of social life on the part both of the eapitalist and the operative," and of an agreement between them "upon common principles of social action." And still more emphatically in his address on "Universities, Actual and Ideal," ${ }^{1}$ he invokes what he calls moral and religious philosophy as a study which, though speculatively limited and criticised by the mental and physical

1 Science and Education, viii. 
sciences, is yet "practically the most directly valuable of all forms of knowledge."

In saying this I do not wish to be understood as maintaining that the abstract study of philosophy must constitute a necessary part of all liberal education. But this I do venture to say, that any student who has failed to realise in the course of his education the great lesson that philosophy at its best has always taught, viz. how utterly subordinate all knowledge and all art is to the practical needs of humanity, has failed to learn the deepest lesson that liberal study has to teach. This has been so splendidly expressed by the greatest of modern philosophers that I cannot forbear quoting his words: "I am myself," says Kant, "a student by inclination. I feel the whole thirst for knowledge and the covetous restlessness that demands to advance in it, and again the satisfaction of every step of progress. There was a time when I believed that all this might constitute the honour of humanity, and I despised the crowd that knows nothing. It was Rousseau who set me right. That dazzling privilege disappeared, and I should think myself far less useful than common artisans if I did not believe that my line of study might impart value to all others in the way of establishing the rights of humanity." The language, of course, is that of his own time, but the truth that Kant here indicates is for all time. Shortly expressed, it is that knowledge is one thing, wisdom is another, and that the first only merges in the second when it comes to include the knowledge of its own place and value in the Whole of human life.

In all this I have been trying to describe what education ought to be. It ought, it appears, to include a fairly advanced knowledge of both science and litera- 
ture, and the bearings of both upon life. But is not this ideal opposed to the whole trend of modern educational organisation? Is it not like Plato's own scheme of a perfect Republic, a city in heaven, and likely to remain there? Is it not, for example, opposed to the present tendency to make a broad distinction in University studies between the two branches of art and science, and to offer them as practical alternatives to undergraduate students-a tendency of which the London University degree courses (a subject painfully living to some of us) is only one among many indications?

To this objection I might reply with Plato that such a scheme may be none the worse because it is an ideal. If it is out of touch with facts, so much the worse, we may say, for the facts. But I wish to be practical, and with this view ask you to consider for a moment what the facts really are in respect to the present tendency. That the tendency exists is perfectly plain. The question is of its origin and probable permanency. With regard to the former, there can be no doubt that it had its source in the reaction which began some half a century ago against the older ideal of a purely classical education. In the controversy which then raged between the supporters of literature and science each claimed exclusive possession of the body of liberal education. London University therefore in its wisdom, like Solomon of old, gave judgment that it should be divided between them. The ideal of an advanced system of liberal education, in which literature and science should be recognised as constituting mutually complementary elements, was consciously abandoned as impossible or undesirable, although in standing proof that it was neither there existed at the time 
across the Tweed a system of which this combination was the essential feature, and which had worked with extraordinary effect upon the character of the people for many generations. I do not, of course, hold a brief for the older Scottish system. Attendance at any University is sufficient to dispel the illusion of educational perfection. But I should like to call attention to this one feature of it, viz. its breadth of aim and its effect on the intellectual life of the country as a whole, and to ask whether this does not suggest that in future organisation we should take into account the need of the great mass of our students for such an education as will best teach them the meaning and possibilities of life rather than one which inevitably tends, as experience shows, to the atrophy of one whole side of their nature.

I do not, of course, ignore that other function of a University - the duty which each generation of teachers has entrusted to it of inspiring the best students with the love of truth in particular departments, and thus training up a band of searchers and discoverers who may succeed it-

"Like runners handing on the torch of life."

I merely wish to call attention to what is most pressingly required in the case of the vast majority of our students ; and, further, to suggest the question whether even in the case of the selected few there is any better preparation for their work as investigators than that which a broad and liberal culture affords. Surely it still remains to be proved that science is the gainer and not the loser by "plucking the unripe fruit of wisdom" and pressing undeveloped minds into the service of special study. 
But I speak probably to some to whom the choice of the wider or the narrower ideal is no longer open, who are already perhaps in the great maelstrom of the London degree and who have little time even for the supplementary study of subjects outside their own of which I have already spoken. What is the bearing for them of such an ideal? To state it gives me the opportunity of introducing an important qualification of the statement made at the beginning of this address as to the respective functions of art, science, and philosophy. We must, I think, agree that there is a distinction and that it is important to recognise it. Yet we should be wrong if we were to take it as a distinction between subjects wholly. I sometimes am inclined to think that the distinction between "faculties" in our colleges is a survival of the old fallacy of supposing that the human mind itself is divisible into separate powers or faculties-a faculty of will, a faculty of reasoning, a faculty of feelingeach independent of the other, and that in stereotyping it as we do in our Universities we are on the wrong track altogether. As we have modified the psychological view on which it is founded, recognising that the mind is an indivisible whole, that though it is distinguishable into parts, each with a special function of its own, yet each part reflects the complex structure of the whole and never acts independently of the others, so we ought to recognise that each department of knowledge, though it appeals to a special side of the mind and thus performs a special function in education, yet just because it is a part of the organic whole we call the World cannot fail to touch the mind on every side as well. To illustrate from familiar instances. Science, we know, when it is studied in the right way fosters in 
the student the power of careful and exact observation, clear and precise statement of results, confidence in maintaining an opinion which he knows to be well founded, openness of mind to new evidence in the case of one he knows to be doubtful. But these are not only intellectual qualities, they imply moral qualities as well: veracity, courage, modesty, surely the most valuable he can possess for life in general. The student therefore only needs to reflect upon the ideal which daily inspires him in his scientific work to derive from it that sort of criticism of life which philosophy aims at supplying in detail. Again, who doubts that there is a way of teaching science so that it becomes a means of developing not only a sense for truth, but a sense I for beauty, of training not only the mind, but the feelings. Even the forms of scientific demonstration have their beauty. The Prince Consort, who (whatever he knew of science) knew something of music, used to say that good reasoning always affected him in somewhat the same way as a musical harmony. I need not stop to illustrate the complementary truth that literary study alone may develop in some degree the whole mind of the student. No one doubts that the study of language may be a valuable training in scientific method, or that art and poetry may be, even without the aid of philosophy, a criticism of life. To come instead to the moral. While holding that where it is open to us the best and surest way of achieving the desired result is by a broad course of study, it is yet possible to reach the same result in another way, seeing that the result depends as much upon the spirit in which study is pursued as upon the choice of studies. The essential thing ( $\mathrm{I}$ repeat it) is that your study, whatever it is, be pursued in a truly liberal spirit, i.e. 
that you try to forget for the time the special requirements of trade or profession, even as far as possible of examination and degree, loving knowledge and beauty for their own sakes, remembering withal that your studies here are only the beginning of your true University life, the education which a wide and comprehensive experience alone can give.

I have tried, ineffectively enough, to bring before you to-night the ideal of a liberal education as complete mental development. It is, I think, the modern ideal. Yet the clearest and best expression of it I know comes to us from a teacher in that stronghold of classical learning - that home of lost causes - the University of Oxford. In an essay on Personality ${ }^{1}$ the late Professor Wallace, who himself combined in a unique degree the qualities of science, poetry, and philosophy, writes:-

"Mental health and wealth do not depend on a mere accumulation of single facts, but on solid ideas of what life is and ought to be, and what the world around us really means : it does not lie in confinement to a fragmentary life, limited in its range and view and moving for ever in the same monotonous routine, but in a large and free scope of experience; nor does it lie in the degree of variety and intensity to which we can bring our sensations and aspirations, but in acquiring the proper estimate of values, in calming the turmoil of temper and gaining at once 'sweetness and light,' that gentle reasonableness which, though not less free to receive impressions than in the beginnings of life, is at the same time matured by experience to a wiser judgment of their comparative worth. The true ideal of a fully developed personality does not consist merely in a keen intellectual acumen, nor in an intense but inactive 
susceptibility to the moods of happy feeling, nor in a perpetual unresting activity; it involves a balance of all these elements."

The writer adds, with characteristic modesty and self-distrust :-

"But few, if any, reach this ; and if this be perfect health, 'wir sind,' as Lotze says, 'fast alle krank." "

Yet, the ideal is before us, and it is for us as individuals, and as a College, to hold to and stand for it.

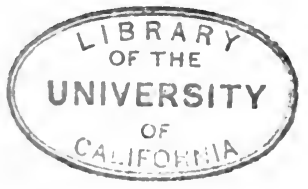


IX.

\section{PSYCHOLOGY AND EDUCATION. ${ }^{1}$}

$A^{S}$ the early part of the nineteenth century was a A great epoch for physics, the middle of the century for biology and physiology, it looks as though the latter part of it and the beginning of the new century were likely to be marked by an unprecedented interest in psychology. "No Edison and no Roentgen can make us forget that the great historical time of physics and physiology is gone," writes Professor Münsterberg, himself a distinguished worker in more fields than one, "psychology takes the central place and overflows into all channels of life." One field especially has been inundated and its workers inspired with hopes of an abundant and hitherto undreamt-of harvest.

The idea of a Science of Education is, of course, not a new one. It is as old at least as the publication of Herbart's Algemeine Pädagogit in 1806. But it is only in our own time that it has attracted general attention, and that any organised attempt has been made to apply it to the work of the teacher. This application was rendered possible by the great advance in the basal science of psychology connected with the names of Volkmann and Wundt in Germany, Spencer and Bain in our own country. But it only became an accomplished fact when the adoption of a national system

${ }^{1}$ Lecture given to the Birmingham Branch of the British Child Study Association, 1901. 
of education forced upon us the task of securing an adequate supply of trained and certificated teachers to administer it. Since then the interest in scientific method has blossomed into a universal system of Kindergarten Schools, and has ended by becoming articulate in a score of pedagogical journals and in a series of admirable monographs on the art of teaching and on the scientific study of childhood.

In this movement America, amply provided with endowments for psychological research and stimulated by the lectures and writings of some of the most distinguished of living psychologists, has taken a leading part. Not only are the ordinary University courses there attended by crowds of eager students, but special courses at the summer schools, largely frequented by men and women actively engaged in the teaching profession, keep alive and extend the interest implanted in their student days. To the ordinary introspective and observational methods of psychology there has, moreover, been added in recent years the excitement of the experimental methods of the laboratory, which has thus become the centre of new and undefined hopes for the future. Here at last there seems a chance of establishing the science of education on a secure foundation of data as precisely measurable and expressible in mathematical formulæ as those of physics and mechanics. In this country, although our Universities as a whole are as yet innocent of this latest development, and from lack of opportunity we have as yet escaped the intoxication of the microscopic methods of the psychological laboratory, yet the circular, the statistical table of observations, the diary of mental history, have become familiar instruments of inquiry, and a large portion of the teaching profession 
has conceived the idea of organising itself into Child Study and similar associations for more systematic effort. These societies do not confine themselves to the study of the cut-and-dry results that have found their way into text books; they aim at the collection and arrangement of fresh facts which may in due time blossom into reliable generalisations to extend the science and improve the practice of education. Encouragement from the higher authorities has not been lacking. One of our first psychologists has accepted the presidency of the British Child Study Association, and even so cautious a writer as the wellknown author of Common Sense in Education and Teaching has added his blessing upon the movement. "The study," Mr. Barnett writes, "which seems to be of next importance for the practical teacher is Psychology, and particularly the physio-psychology which is represented by such names among others as Professor James and Professor Lloyd Morgan." He adds that "after interrogating tradition, the teacher's next chief business is to make the best he can of his own opportunities for gaining experience and making experiments. His own honest and original observations and investigations are of more value than the records made by a dozen other people, however acute they may be."

Anyone who has watched this movement from the commencement, recognising its promise, yet unable to shut his eyes to the confusion of mind that underlies some of its most striking phases, must have foreseen that a reaction was bound to follow. It is interesting, and not without its humour, that the first and strongest note of reaction should come from the University which more than any other has given life and direction to this new enthusiasm. Harvard, like Frankenstein, 
has raised up a monster which it now vainly endeavours to control.

First came Professor William James with his pleasant chaff of "brass-band Child Study," and more definitely, in his Talks to Teachers, with an earnest protest against the folly of adding the duty of psychological research to the burdens of our already overworked profession. The "new psychology," he assures his hearers, is a delusion, and of the old it is only the fundamental principles that are of real value to the teacher. Even these, he takes care to warn us, are of a negative rather than of a positive utility,like the demon of Socrates a voice of warning rather than of suggestion and encouragement.

Next comes Professor Münsterberg, driven out of all patience by the misunderstandings and the crudities of his too enthusiastic followers and fain to take up arms in the interest of truth and sanity against the assumption on which the whole movement is founded. Beginning with a criticism in the Atlantic Monthly of the idea of an exact science of psychology based on quantitative measurement of mental states, he is carried on in a series of subsequent articles, happily republished in a separate volume, ${ }^{1}$ to reflections on the kind of statistics that pass current in pedagogical seminaries and magazines for genuine investigation. These are either, like a recent collection of juvenile love-poems, not psychological at all, or, like others equally fatuous, merely illustrate what we already know and are of no more value than would be statistics of falling stones collected with a view to establishing the law of gravitation.

1 Psychology and Life, by Hugo Múnsterberg, Professor of Psychology in Harvard University. 
But Professor Münsterberg has a deeper objection to the invasion of psychology by the teacher than the amateurishness of the results and the caricature of scientific method it offers to the outside world. $\mathrm{He}$ holds it to be radically opposed to the ends of true education. Not only is there a danger to the child's natural development in the artificial stimulations and tensions which genuine experiment must involve, or (where this is avoided) to their innate naïveté and modesty; his main objection rests upon the nature of psychology itself as involving an attitude fundamentally opposed to that of the teacher. Psychology, it is claimed, is a science; but if we are in earnest about this claim, we must submit to the conditions which render science possible. In the first place we must make abstraction. Scientific description and explanation are here only possible if we treat the mind as consisting essentially of impressions and ideas. This involves the treatment of it as "presentational" to the neglect of the elements of will and purpose on the one hand, feeling or sense of value on the other. Such a transformation carries us far enough from the concrete reality of the mind or soul as we know it in ourselves and our fellow-men. But we are carried further still when in the interest of science we proceed to analyse these presentations into psycho-physical atoms, varying in the attributes of quality, intensity, and vividness according to the strength and local direction of the stimulus. This "atomising attitude," essential as we may believe it to be in the interest of science, is clearly antithetic to the attitude of practical life and to the natural instinct of the teacher. "You destroy a consistent psychology if you force on it the categories of practical life, but you also destroy the values of our practical life if you 
force on them the categories of psychology. In experimental psychology or in child psychology emotion may show itself as composed of circulatory and muscular elements and the will as made up of muscle and joint and skin sensations; but if you offer such transformed products to the teacher, you do worse than if you should offer to a thirsty man one balloon filled with hydrogen and another with oxygen, instead of a good swallow of water. The chemist is quite right: that is water; the fainting man insists that it is not, and life speaks always the language of the thirsty."

All this we must admit to be sound common sense. It is well to be warned in time against exaggerated expectations of what psychology, even as ordinarily interpreted, can do for the teacher. The essential qualities of the good teacher, besides a knowledge of his subject, are those which are born with him, or acquired by quite other methods than a training in psychology, viz. love and understanding of children, tact in dealing with them, patience with their weakness, sympathy with their purposes, interest in the work of doing what he can to make them into useful inen and women. These, as Professor Münsterberg insists, are infinitely more important for the teacher than any psychological observations he can make upon them. It is well, further, to be warned of the peculiarly abstract point of view from which one powerful school of psychoiogists, of which Professor Münsterberg himself is the leader, regards the problems of psychology. No error truly could be more disastrous than to take the "transformation" of its classrooms and laboratories as a true account of the life of the soul with which the teacher has to do. 
But after all this has been granted, the question remains of the inward meaning of the remarkable movement that has called forth these protests and of the value we ought to assign to it. Granted that this new-born zeal for the scientific study of what has been happily called the "object," as opposed to the "subject" of education, has for the moment taken a wrong direction, it is not enough-it is not itself good psychology-merely to give it check without vouching any indication of the direction in which it may more fruitfully be turned. Yet on this subject the above criticism, sound though it is in itself, throws but meagre light. Professor Münsterberg tells us, indeed, in an earlier article (unfortunately not reprinted along with the others), that "when the rush to illusory measuring psychology is over, the teacher ought to go back to the solid, sober, qualitative analysis of the human mind," where, he is assured, "he will find plenty of help for his sacred educational work." But the writer omits to supply us with any adequate up-todate account of the scope of this qualitative psychology, the precise relation which it bears to the work of the teacher, the relation, on the other hand, which the practice and experience of the teacher bears to the work that psychology has still to do. Leaving, then, meanwhile, these suggestive criticisms, I propose in this paper to try to state in outline the answer to this question that the present state of philosophical opinion seems to indicate. The question, or group of questions, thus defined comes, it will be admitted, to be one of considerable general importance at a time when, alike in the older and in the newer Universities, we are not only engaged in recasting the schemes of study designed for the training of elementary school 
teachers, but are likely to be called upon in the near future to provide courses which may meet the increasing demand for trained and certificated teachers in secondary schools.

It is agreed on all hands that if there is to be a Science of Education it must rest on Psychology as its central pillar. Since the time of Herbart it has been a commonplace among educational writers that while it is for Ethics to determine the end of education it is for Psychology to determine the means. Between them, therefore, these two sciences constitute a discipline which may be said to stand to education as physics and mechanics stand to engineering, chemistry and physiology to medicine. Our first question refers to the sense in which the latter of the two must be taken if this claim is to be substantiated. From what assumptions does it start? What area of knowledge does it cover?

If we turn to the current application of the term Psychology in English, it must be admitted that its connotation is sufficiently vague. Speaking of the common acceptance of Philosophy in England at the beginning of the nineteenth century, Hegel complained of the indefiniteness of its scope, quoting in illustration a newspaper advertisement of a book on "The Art of" Preserving the Hair on Philosophical Principles, neatly printed in post 8vo, price $7 s^{. "}$ A similar complaint might be made of the word "psychology" which today has taken its place.

1. In the first place there is the meaning to which the ordinary text books attempt to give currency: the account of the states and operations of the mind under the three recognised headings of knowing, feeling, and willing. So interpreted it has never succeeded in 
striking the popular imagination as a very brilliant or helpful achievement. From the beginning it has suffered from a fatal vacillation between the commonplaces of ordinary observation - "telling us what everybody knows in language that nobody can understand"- -and incursions into metaphysics, for which it is inadequately equipped. One vital defect it is apt to exhibit at the outset. Starting with a claim to constitute a natural science in the same sense as physics or chemistry, it makes no serious attempt to understand the assumptions (e.g. the quantitative identity of energy) on which the natural sciences are based, or to give any coherent account of the sense in which these assumptions are applicable to the phenomena of mind. Accordingly it has no sooner entered this claim than it plunges into discussions as to the nature of knowledge, feeling, and volition which proceed on the wholly opposite assumption that these conditions are altogether inexplicable by any method known to natural science. No one who has suffered from these inconsistencies can fail to acknowledge that Professor Münsterberg has performed an important service to mental philosophy in calling attention to them. The cure must be sought in one of two directions. Either we must be prepared to treat its data throughout in the only way consistent with our assumption, or we must frankly abandon all attempt to co-ordinate psychology as a whole with the sciences which aim at description and explanation in the ordinary sense.

2. We saw that Professor Münsterberg himself advocates the first of these alternatives. But having led the way in the construction of a "consistent science" of psychology, he has recently been awakened 
by the mistakes of his over-zealous followers to the danger of misunderstanding, and especially to the utter wrong-headedness of the expectation that the results thus achieved can be of any direct utility for the practical purposes of life. So far we are at one with his conclusion, the only question that remains being whether it does not carry him further than he intended to go, whether the argument does not prove too much. The method of abstraction is of course defended on the grounds of the new insight that may be reached by it into the concrete processes of mental action. But if the results reached are so remote from reality as is contended, its advocates may reasonably be asked to be more precise in explaining the exact nature of the gain they expect to accrue from so elaborate a metamorphosis. To go at once to the crucial point. Granted that mind is essentially purposeful effort, that it cannot otherwise be understood (and on this all who count are now agreed) than as a process guided by interests or ideals, however obscurely present to consciousness, what, we may ask, is the precise nature of the insight into it which we are likely to derive from a science whose Alpha and Omega is to shut our eyes to everything that the idea of purpose implies? By doing so we have not only transformed the object, we have deprived ourselves of all means of describing it. With "will," "interest," "emotion," "motive" must go also "intelligence," "imagination," "perception" itself. We may call our aggregate of atomic states the "mind" if we like-we are bound to call it something. But it is no more the mind that we know than the skeleton of the anatomical museum strung together with wires and galvanised into mechanical contortions is the living body of a 
man. It might be urged in reply that the same objection would hold of physics as at present taught. Here, too, we are dealing with an abstraction. The physicist calls it matter; but the student has not gone far before he discovers that the matter of the physicist is something wholly different from the matter of everyday life and conversation. Yet this does not trouble him or prevent his reaching results of the highest value both for theory and practice. There is, however, an important difference in the two cases. While matter at best, to all but the crudest materialists, is a patent abstraction, mind is a concrete whole, embracing, as all modern philosophy since Berkeley has taught, the distinction between inner and outer, mind and matter itself, and therefore admittedly inexplicable as a whole by the forms of thinking which it applies to the abstracted parts or aspects of its life. To treat it, therefore, as though it were part of a mechanical system of nature-a system which can only exist for a mind-is to adopt a method so obviously inadequate that the investigation can only be conducted with continual reservations, hampering its operations and invalidating its results. It can hardly be wondered at that a science which takes such an abstraction for its starting-point should still remain, as Professor Münsterberg complains, in the position that physics occupied in the fifteenth century.

These objections are not of course intended to apply to the new experimental and microscopic methods, but only to the attempt to identify them with an experimental "psychology" setting itself up as an independent republic with its own assumptions, its own "consistent" system of results, within the empire of mental philosophy. From such an attempted isolation 
nothing but time-wasting conflicts are to be expected, which can only end in the re-annexation of the territory claimed with diminished prestige to all concerned. The example of a kindred science, one would have supposed, might have served here as sufficient warning. The science of political economy was long haunted by the abstraction of an economic man endangering the peace and even threatening the existence of a sane sociology. The misunderstandings to which this gave rise only ceased with the banishment of the science which took it as its starting-point to a distant planet. Yet on any fair estimate of abstractions the "economic" man is a plump reality as compared with the "psychologic mind."

3. But because the attempt to construct a consistent science out of the current psychology fails to commend itself on closer inspection it does not follow that nothing at all can be made of it. It may be possible to make it consistently philosophical, if not consistently scientific; to treat mind throughout as will and personality, and to endeavour to render intelligible from this point of view the end in knowledge and action it seeks to realise, the stages it traverses, the means by which it helps itself forward in its normal progress from less to more. So interpreted in antithesis to the abstraction we have just been considering, psychology might be called concrete. It is concrete in the first place in that its aim is to understand the nature of mind as a whole, treating it from the outset as essentially will and idea, instead of as a "bloodless dance" of automatic presentations. It is concrete, in the second place, in consistently regarding the mind as dominated and moulded throughout its entire structure, however unconsciously, by a universal ideal of internal 
unity and coherence, apart from which none of its particular ends can be truly understood. Nothing probably has so impeded the development of a rational psychology, or so aided in spreading the impression of the practical impotence of the study, than the feebleness and vacillation with which psychologists as a rule have handled the central doctrine of the unity of the mind's ideals. It is concrete, in the third place, in the sense that it refuses to treat the mind of the individual in abstraction from the corporate mind, to which it stands in the relation of part to whole. It is not the least dangerous of the delusions which text-book psychology encourages that the essential attributes of the mind of the individual can be understood apart from the mind of the community to which it belongs and which at every moment it presupposes. Concrete psychology will aim at counteracting this one-sidedness by insisting on the inclusion of the mind of the community, and especially of the forms and institutions by which it seeks to establish itself and make itself at home in the world, within its scope: art, language, science, and religion. If it be said that this enumeration is the reductio ad absurdum of such an interpretation of psychology as is here suggested, and that I am really describing a Philosophy of Mind which, in addition to psychology in the proper sense (however it is to be taken), includes the elements of logic, rsthetics, ethics, and religion, this need not distress us. It is no real objection in philosophy to be told that the margin of its parts fades as we move. We have here left the region of scientific frontiers, and if the outlines of our subject remain somewhat shadowy, it is at least safe from the charge of inconsistency on the one hand, wholesale falsification 
of the facts upon the other. As philosophy, moreover, which as Plato tells us is synoptic, it has the advantage of being able to combine and include all that is best in the other psychologies. It will include, for example, all that the text-book psychology has to say on the organic relations of the elements of mind, feeling, knowledge and volition, the admirable accumulated observations on the nature of habit and the origin of volition, the conditions of pain and pleasure, and the natural history of the conscience. It will even find much that is of value in the ordinary account of the laws of association, only protesting when asked to accept as a final or in any way intelligible explanation the hypothesis that ideas act mechanically on one another by the law of contiguity, instead of following the all-pervasive principle of continuity of interest. Similarly it will welcome all the light which microscopic methods can throw on the subtler relations between mind and body, on the sensational elements that enter into feeling and volition and on the conditions of attention and reproduction. It will only refuse to follow the new psychology when, to borrow Professor Münsterberg's own distinction, it claims to be treated as an end, instead of as a beginning, as a science on its own right, instead of as a powerful method for extending our knowledge of the concrete organism we call the mind. Taken in this way and with this qualification, we agree with Professor Münsterberg that "a good psychology is the most important supplement to these sciences, which consider the inner life not as an existing, describable, explainable object, but as a will-system to be interpreted and to be appreciated. Psychology as an end is the last word of the naturalistic century which lies behind us; it may become a begin- 
ning as the introductory word of an idealistic century to be hoped for."

Our review of the different senses in which psychology may be understood has already anticipated the answer to the question in what sense it must be taken when we speak of it as the chief corner-stone of the Science of Education. In education we are dealing with the concrete life of the soul, and it is only as rectified and enlarged in the sense explained that psychology can be expected to offer any real help in the solution of its problems. The difficulty begins when we go on to propose that the study as so understood should be adopted as the basis of the curriculum of the Training College. Where is such a concrete psychology to be found? What text books are available for the student? Or, granted the available means, what particular necessity is there for the individual student to avail himself of them? Is it not one thing to insist that our schemes of study and hints about method should be in harmony with the best that is known to philosophy, quite another to insist that the individual teacher should be a philosopher?

With regard to the first of these questions, it must be admitted that there is a lamentable dearth of literature in which, while the attitude of the writer is consistently philosophical, the treatment of particular points is sufficiently detailed and well-informed. Help may indeed be obtained from the ordinary text books, parts of them are excellent. The best of them, like - Professor William James's and Dr. Stout's, are indispensable, and if supplemented by such books as

- Professor Baldwin's Social and Ethical Interpretations

- of Mental Development, Dr. Bosanquet's Psychology of the

- Moral Self, Professor MacCunn's Making of Character, 
will form a solid foundation on which the teacher may securely build. But his chief resource must always be the great classics of the subject, of which Plato's Republic, Aristotle's Ethics and parts of his Psychology

- and Politics, Hegel's Philosophy of Mind (the first, with the wealth of comment that has in recent years accumulated, probably by far the best) are types. These have from the beginning constituted the most valuable part of the courses of study recommended in Training Colleges. "In the study of education the book on psychology," writes Mr. Barnett, "is a positive danger unless a classic is read also as an antidote to pedantry." And even when the books on psychology have ceased to be pedantic, the classic will continue to be the surest foundation of a true science of education.

If it has to be admitted that the principles of a concrete psychology have to be sought for in a species of literature somewhat unfamiliar and, it may be, inaccessible to the ordinary reader, it ought to be added that illustrations of them are not far to seek, and that the general literature of our time is peculiarly rich in the portrayal of concrete types of character. Some poems of the Brownings, some chapters in George Eliot and Meredith, contain more good psychology than a whole library of text books. And what is true of the study of mind in general is true of the study of the child's mind in particular. It would be difficult probably to point to a thoroughly satisfactory text book on Child Study. But this is no great cause of regret so long as it throws us back upon the concrete studies of Stevenson, Du Maurier, Meredith, Kenneth Grahame, Daudet, Renan, and, on a different level, Mr. Barrie and Mrs. Ewing. These are the true leaders of Child Study, 
putting us, perhaps for the first time, in touch with the real mind of the child.

Our answer to the first of the above questions has, however, brought out more clearly than before that it is no insignificant addition that is here proposed to the curriculum for Diplomas in Teaching. Against such an addition the humanitarianism of Professor James protests, leading him to declare, at the beginning of Talks to Teachers, that it is only the fundamental conceptions of psychology that are required, and that these may almost be written on the palm of the hand. My whole object, however, in writing this paper is to show that the future of education is to a large extent bound up with a much more serious study of the principles of moral development. In the Training College, as elsewhere, a little knowledge is a dangerous thing. If it were possible to ignore theory altogether, we might be tempted to agree with Professor James. But it is not a question whether or not the teacher shall be a theorist. He cannot open a book or paper on his professional work, hardly a book or paper of any kind, without imbibing theory upon life and mind. The only question is, whether he shall be in a position to know good theory from bad. The late Professor Henry Sidgwick claimed that the chief function of the philosopher was to protect the public against other philosophers. This service at least the psychologist can perform for the teacher: he can protect him against other psychologists. Even the theory of "method," to which so much importance is rightly attached in Training Colleges, is only safe when taken with a large admixture of the fluid principles of which it is the application. One of the most pathetic features of the present state of matters is the determination of 
the trained teacher, at all hazards, to live up to the half-understood canons of his profession. ${ }^{1}$

But it is not only on the ground of the protection it affords the teacher against bad psychology and doctrinaire method that the serious study of first principles is desirable. The most important argument in its favour is the revolution in his whole attitude towards his work that it tends to bring about. It has been suggested that the studies we are speaking of bear to teaching the same relation that mathematics and physics bear to engineering. If the analogy is valid the inference is plain. It is, of course, open to the teacher to content himself with a working knowledge of rules of method, as the artisan may content himself with the mechanical dexterities required for the practice of his trade. But if the artisan is to become the artist, the mechanic the mechanician, it can only be through familiarity with the principles of physics and mathematics. Similarly, if the teacher desires to be more than a skilled labourer, if the position he claims and the world is happily prepared to concede to him as a member of a learned profession is to be justified, it can only be by familiarity with the more abstract principles on which the practice rests. I know, of course, all that can be said for the born teacher as for the born mechanic. In both cases we have to admit that the geniuses are born and not

1 This would be often amusing if it were not so disastrous. I was lately present at a lesson on the Canterbury Tales given by an elementary school teacher. Conformably to the canon of linking new knowledge to old in the children's mind, the teacher met the ignorance of the class as to the geographical position of Canterbury with the statement, "You have all seen in the butcher's shop you pass, by the school door, meat that is ticketed 'Canterbury lamb.' Well, the Canterbury we are talking about is not that Canterbury." 
made. But when all is said and admitted, it still remains true that the teacher who, having a chance of gaining what insight is possible in the present state of knowledge into the structure of the human mind and will and the conditions of its proper development, neglects to take advantage of it, deliberately chooses the lower for the higher plane, and dooms himself under ordinary circumstances to the life of the uninspired journeyman, when he might have prepared himself to be a master in his craft. It is less necessary to labour this point as Professor James has himself put it in a telling form. Speaking of the value of knowledge of psychological theory to the teacher, he says: "Most of all it fructifies our independence, and it reanimates our interest to see our subject at two different angles, to get a stereoscopic view, so to speak, of the youthful organism who is our enemy, and while handling him with all our concrete tact and divination to be able at the same time to represent to ourselves the curious inner elements of his mental machine. Such a complete knowledge as this of the pupil, at once intuitive and analytic, is surely the knowledge at which every teacher ought to aim."

There is, however, one point at which a knowledge of first principles comes to be so closely. connected with the future of education that it seems to deserve special notice. We have contended that the teacher's view of end and means in education is definite and coherent in proportion as it is connected organically in his mind with the best ethical and psychological doctrine of the time. By this it is not meant that he may not obtain workable ideas on these subjects from lectures and handbooks on education, but that these ideas are a sure mental possession, gain depth 
and significance and develop the capacity effectively to resist the pressure of opinion in favour of lower, less comprehensive ideals, only in so far as they become part of a coherent view of the inner nature of life and mind. Now while it is true that there never was a time when such pressure was not exercised, it is equally true that it was never heavier than at present. Finding our industry and commerce threatened on every hand, we are turning attention to our present system of education as the chief cause of our failure. Instead, however, of going to the root of the matter, and inquiring what the aim of all sound education ought to be, and wherein we fail in realising it, we have fixed on a few superficial defects: the absence of the directly utilitarian element, the secondary place we assign to modern foreign languages, the abstract and unpractical character of classical and mathematical teaching, ignorance of technical processes, commercial geography, and industrial history. Much that is said on all this is most true, especially as it concerns the teaching of modern languages and the traditional methods of instruction in classics and mathematics. But behind it all there is a current of superficial utilitarianism that bodes ill for the ideal of truly liberal education that has been upheld in an unbroken tradition by all the great philosophical writers from Plato and Aristotle to John Stuart Mill and John Ruskin. If that ideal is to hold its ground it can only be through the reasoned conviction in the minds of the teachers themselves that its validity remains unshaken. If this defence gives way, the present generation is likely to witness a reaction in favour of an idea of education which sacrifices the substance for the shadow, all-round training of the essential elements of mind, judgment 
and imagination, feeling and character, for acquired dexterity of hand and intellect in what is immediately useful. I do not say that the things which the philosophers have approved have now the prominence that is their due in the educational system of the country, but only that the future of education will to a large extent depend on the spirit of the instruction given in normal colleges and the depth and sincerity of the conviction with which the educational world in general holds to their fundamental importance.

Hitherto I have dealt with the relation of psychology to the work of the teacher, but a further point was raised at the beginning of this paper as to the converse relation of the teacher to the work of psychology. On this subject we have seen that the present attitude of the psychologists is distinctly discouraging. Not to mention Professor Münsterberg's more serious objection to the teacher's participation in psychological research, it is urged that the work of the teacher is quite enough to occupy all his attention, and that it is a poor service to the profession to tax it with the additional burden of contributing original observations to the science of pedagogy. As Professor James puts it, "The worst thing that can happen to a good teacher is to get a bad conscience about his profession because he feels himself hopeless as a psychologist. Our teachers are overworked already. Everyone who adds a jot or a tittle of unnecessary weight to their burdens is a foe to education. A bad conscience increases the weight of every other burden."

Here too, however, there is danger of exaggeration and of too indiscriminate reaction. The psychologist's harvest truly is plenteous and the labourers are few. One might expect him, therefore, to think twice before 
rejecting aid from any quarter. More especially we might expect him to hesitate before he quenches the smoking flax of the teacher's interest in the fundamental problems of his science. If, as Professor James seems himself to say, it is only the psychologically trained teacher who has the stereoscopic view of the child's mind, who better equipped than he for the observation of its concrete working? Who especially has better opportunities than he of observing the development of mind, the genesis of its ideas and sentiments, above all, the genesis of the central idea of personality, the central sentiment of morality? Granting the wisdom of Professor Münsterberg's remark that Child Study ought to be a method and not an end, that it ought to be done individually and not statistically, by professionals and not by dilettants, more by natural observation and less by experiments, we ought to remember that the line between dilettant and professional is here a very narrow one. Professor Münsterberg, in an interesting passage in his chapter on "Psychology and Education," speaks as though he conceived of the material for the science of education as being supplied by expert psychologists, worked up by a body of officials into a system of obligatory prescriptions and then handed on for application by the practical teacher. Needless to say, any such idea, if taken seriously, would be the ruin of pedagogy. Nor does it receive any support from the example of Herbart by which the writer seeks to illustrate his contention. The value of Herbart's suggestions depended on the very combination in him of the psychologist and the teacher which Professor Münsterberg deprecates. It was just at the point where his experience as a teacher failed him that his utterances 
were apt to become enigmatic and doctrinaire. In the development of such a science as that of education, it is essential above all things to keep it fluid, and this can only be done if those who have to administer its "prescriptions" possess an intelligent appreciation of the principles which underlie them, the limits of their application, the open possibility of reaching a more accurate statement both of principle and prescription as a result of maturer experience. It is only as an operative system in the mind of the teacher that the science of education can be of any value, and all the "analogies of experience" go to prove how fallacious is the distinction between the application and the improved formulation of scientific principles. Every intelligent application is itself an experiment of precisely the same kind as led to the original formula, and to cut ourselves off from the active co-operation of the teaching profession in the systematic development of the theoretic side of education is to cut ourselves off from our most useful allies. It is to run counter to one of the most hopeful educational tendencies of the present time, the attempt to establish a closer working partnership between the City and the University.

As to the bogy of the burdens of the teacher, we may leave him to see to that. Those who have had most experience will probably agree that there is no burden so oppressive to the teacher as the sense of being confined to ends and methods he is incompetent or forbidden to criticise; nothing, on the other hand, so invigorating as the sense of the value of his own individual experience in its bearing on vital and still open questions of education. Original observation as to laws of mental and moral development is, of 
course, a special gift, and true builders in the science of education, as in other sciences, are few and far between. But it requires no special gifts to be an intelligent member of a teachers' association, or a reading circle formed for the purpose of discussing problems of life and mind as they affect education. No genuine experience but may here be of value. Though we may not be able to see its precise place in knowledge ourselves, others may, and we may at least have the encouragement of contributing the mortar for the builder's work.

My object in this paper has not been to urge that a complete course of psychology should be a necessary part of the training-college curriculum. This truly would be to bind upon the students a burden too heavy to be borne. All I would urge in this connexion is that there are a few well-attested results of general theory with which, in a short course, candidates for diplomas ought to be made familiar, if only to encourage in them a certain attitude of mind towards their future work. My object has been to counteract in some degree the discouraging effects which some recent utterances by our leading psychologists may have produced in the mind of the teaching profession. I confess to quite other hopes from the union in this field of theory and practice. I look forward to a fruitful working alliance between the school teachers, both primary and secondary, in any district, and the education department of the local college or university. I can conceive of these two as bound together in helpful association for the furtherance of organised observation and experiment in educational science. For such experiment and observation no psychical laboratory will be necessary. Every school will be a 
laboratory or observatory with its one or two skilled observers and recorders. I can conceive of these observations and experiments in every department of education - physical and mental, intellectual and moral, literary and scientific-conducted with all the care of the chemical analyst, with all the safeguards to the children that the anti-vivisectionist could desire, lasting for weeks or months or years, as the case might be. They might then appear in the form of accurate reports to be read before the members of the local association, criticised, recast, and finally sent out through the medium of journals of educational research to fructify perhaps, wherever English is read, in better, more confident methods of teaching.

These may only be dreams. Yet when others are dreaming of what may result to material development from the union of physical science with commerce and industry, we may be permitted to see our own visions and dream our own dreams of what good may come to intellectual and moral development from a closer union between mental science and education. 


\section{LOGICAL.}



I.

\section{THE PLACE OF THE CONCEPT IN LOGICAL DOCTRINE.}

THERE is nothing in which recent logical treatises 1 contrast more strikingly with the older text books than the complete subordination of the concept to the judgment and the almost total disappearance of the discussions that used to find a place under the head of the doctrine of the term. This change is a natural reaction against the attempt to assign an independent place to the concept as prior to judgment. As against the old view that thought begins with concepts and proceeds to judgment and reasoning, the criticism on which it rests is unanswerable. We may, however, admit this without admitting that the last word has been said on the relation of judgment to concept. It is possible that though the ground on which the older logicians rested their claims for the prior and independent treatment of the concept is untenable, and though there is much that is preposterous in the way in which they developed the doctrine of the term, their order of treatment was yet the result of a true instinct as to the ultimate nature of the movement we call thought and knowledge. This paper offers a few considerations in support of this suggestion. Its conclusions could only be justified by the success which might attend 
the attempt to carry them out in a complete system of logic. Short of this, its length will, I hope, admit of a clear statement of the view in question and a few suggestions as to the change it would involve in the current treatment of logical doctrine.

I.

To clear the ground I shall begin by recalling the present state of the controversy. The criticism of the traditional view may be said to have been successful all along the line. According to this view concepts are formed from groups of particulars by the processes of abstraction and generalisation. Common elements are abstracted and constituted by their union into a general notion which is thenceforth taken as representative of the group as a whole and as predicable of any individual within it. Out of a combination of such concepts we have judgments; out of a combination of judgments, reasoning. Logic, therefore, is not only within its rights in treating the concept as a substantive element in thought; it is bound to treat at length of the various kinds of concept that might be united in. a judgment at the risk of leaving the form and content of the judgment itself unexplained.

Of course it is easy to see that this will not do. Before we can "abstract" an element from any individual thing, we must already have judged the thing to possess it. And going a step further back, and considering what is meant by the "group" of things from which the concept is said to be abstracted, we see that it could only have been formed by looking at the individuals from some point of view, or as 
possessing some attribute, and that to group things in this sense is to make a judgment about them.

For the older logic with its neat system of discussion, beginning with the term, going on to the proposition, and ending with the syllogism, this attack on the independence of the concept was, of course, perplexing. Two courses seemed open to logicians who, while conscious of the difficulty, still desired to retain the old order: either (1) to accept this criticism as theoretically conclusive, but to treat it as practically irrelevant to the order and mode of discussion, or (2) to attempt to combat it on the ground of theory.

1. In a passage $^{1}$ which is interesting as showing more insight into the nature of the thought-process than his school is usually credited with, Thomson states the arguments that might be brought against the attempt to assign logical priority to the doctrine of the concept. "Why," he asks, "do we reason? To find whether some judgment which has suggested itself to our minds be true or not. Why do we seek to make this judgment? To add something to the clearness of the notion that is its subject. Copernicus reasoned to prove the globe revolved round the sun, and he established this judgment that when men thought of 'the globe' in future they might know it as the 'revolving globe.' All the reasonings in Aristotle's Ethics are to give a more adequate notion of happiness, of Plato's Republic to improve our notion of justice, of Bacon's Organon to afford a more accurate conception of method." After these admissions one might have expected him to go a step further and agree with modern logicians 
that if the matter stands on this footing, and concepts are founded on judgments instead of judgments on concepts, the function of logic must begin and end with the analysis of judgment, and that to repeat or forecast this analysis under the head of the concept would be superfluous. ${ }^{1}$ This, however, would have involved a revolution in the whole treatment of logical doctrine for which the formal logicians of the time were not prepared, and Thomson falls back without more ado on the old order. It is artificial, he admits, but in beginning with the concept logic begins with the simplest element of reasoning, and is thus easier to follow.

In reply to this mode of meeting the theoretic difficulty, it is sufficient to point out that it is an odd way to achieve simplicity by trying to explain the natare of contrariety in the contrary and contradiction in the contradictory term, without any reference to the corresponding judgments in which alone they can appear. What, again, is to be said of a method of exposition which treats of division before the disjunctive, definition before the reciprocal judgment, and the whole elaborate scheme of the predicables and the predicaments before it has explained what predication itself implies?

2. The second way of meeting the above criticism was to inquire whether the theoretic argument in favour of the priority of judgment to a concept was really unanswerable. This is the investigation with which Lotze opens his Logic. Lotze begins by admitting that ideas in their developed and accurately defined forms imply the previous activity of judgment: "In order to frame complex and manifold concepts, and

1 See Bosanquet's Logic, vol. i. p. 39. 
more especially in order to fix the limits within which it is worth while and justifiable to treat them as wholes and distinguish them from others, a great deal of preparatory intellectual work is necessary." 1 This, he says, is the truth contained in the proposal to reverse the usual order of treatment. But this proposal overlooks an important consideration. In order that this preparatory work may be possible, "it must have been preceded by the conformation of simpler concepts out of which its own subsidiary judgments are framed." How are we to conceive of this preliminary process? It is not, we have seen, judgment, but neither is it simple impression. A judgment is a construction. To make it we must have the materials ready to hand. On the other hand, it is not any materials that will do. It is easy to make a heap out of nothing but round stones, if it be indifferent how they lie; but if a structure of regular shape is to be built the stones must be already so formed that their surfaces will fit firmly together. This process of shaping impressions into ideas he defines as conception. It consists (1) in the "objectification" of our impressions. We must conceive of the beginnings of knowledge as of something we undergo. But this is only a moment in the process. We go on to separate the sensitive act from the sensible matter to which it refers. The matter or content is stamped with objectivity as a something which has its being and meaning in itself, and which continues to be what it is and to mean what it means, whether we are conscious of it or not. But this is not all. If it were, the interjection would represent the process of

1 Logic, i. 1, $\$ 8$. 
conception equally with the substantive or the adjective. Hence (2) in objectifying, we must be conceived of as giving a definite form to the reality as either subject, attribute, or action. A concept is not merely of reality, it is of reality in a particular form, and the form which it takes must be regarded by logic, at any rate, as given.

A philosopher is known by his metaphors, and anyone who has been taught to regard logic as the "Morphology of Knowledge" will have a shrewd suspicion of a theory which proposes to throw light on the relation between concept and judgment, by appealing to the analogy of bricks and mortar. What is the activity by which Lotze conceives of the mind as giving a definite form to reality, as either subject, attribute, or action, if it does not involve, in however rudimentary a form, processes of comparison and distinction? Or again, what is meant by objectivation if it does not mean the qualification of an objective world by an idea? And what are all these implied processes but rudimentary judgments? They may not be judgments in which subject, predicate, and copula are clearly distinguished, but neither are judgments of the form "there never was a sea serpent," and it is one thing to say that judgment has a beginning in a germ cell in which subject and predicate are as yet undifferentiated; it is another to maintain that this beginning consists of a small store of ready-made concepts, from which the mind selects the material of its subsequent constructions. The whole matter lies in a nutshell. What is it that differentiates a concept from the mere image or impression? There is no doubt about this. Lotze has done more than any other logician to make it clear. It is the objective 
reference we call its meaning. The image is a mere floating content, the concept is an adjective or proprium of reality. But the characteristic which marks it out as a concept destroys its claim to rank as an independent element of thought. For this reference by the mind of an ideal to reality, or, if we prefer it, this appropriation by reality of a floating content is in the last resort what we mean by judgment.

The conclusion is inevitable. If we approach the question, as the older logicians did, from the side of terms and propositions, and inquire what is the relation of the concept as an explicit element of judgment to judgment itself, the only possible conclusion is that it represents "a habit of judging with reference to a certain identity." 1 When I say, "What a lot of buttercups," I mean by buttercups a system of judgments which $I$ am ready to make in reference to a particular object, judgments which I am prepared to make because I have already made them. If it be said this system can at any rate be isolated from the judgment, and is actually so isolated in the ordinary course of human thought, this, again, is pure delusion, arising from the fact that by aid of the term we can isolate an idea from its context and place it by itself as in the case of the name of a street or a heading in an index. In all such cases the term stands for an element either in a categorical sentence: "This is Oxford Street," or in one of as yet undetermined modality : Oxford Street!" "Well, what about it?"

All this is unanswerable, but it does not exhaust the subject, and there is a question which the above criticism leaves untouched. Granted that the first movement of thought is judgment, from what does

1 Bosanquet, loc. cit., p. 41. 
it move? What moves in it? The older view is quite untenable; but it had this merit, that it recognised judgment as a point of transition. Judgment, it held, starts from a datum or data in the concept, and moves forward to a result in a new concept. Logicians have recently been so occupied in demonstrating the crudity of the account which it gave of the terms between which the movement takes place that they have tended to overlook the truth of the intuition on which that doctrine is founded. They have rightly perceived that even the most elementary movements of thought imply acceptance. Just as the psychologist insists upon belief as a primitive element in our conscious states, so the logician maintains that our mental attitude toward reality must be regarded from the outset as categorical. But to say this is only to clear the way for the question whether, just as the object of belief must be regarded as logically prior to the belief itself, so prior to any "attitude" there is that to which the attitude is adopted. The contention of this paper is that besides this categorical element, which I admit is present in all experience, there is also another which may be called an interrogative, and which represents in us the consciousness of an as yet indeterminate totality within which the judgment is made!

II.

Let me try to make this clear. Modern psychologists are generally agreed as against atomistic writers on the one hand and at least one interpretation of Kant on the other that consciousness begins, not in a disconnected manifold, but in an "undifferentiated continuum." The evolution of mind is conceived of accordingly as a process similar to that which takes 
places in any other organism, inasmuch as it exhibits the twofold movement of differentiation and integration. How are we to interpret this starting-point and this movement from the side of knowledge and of logic, the science of the origin and growth of knowledge? The "movement," we may say, offers no difficulty. For logic this movement is the activity of judgment, with its twofold function of analysis and synthesis. But what of the starting-point? As judgment is a process of differentiation, we must conceive of this process as taking place on a background of implicit unity. Before we can have thought in the concrete sense of the union of predicates, we must undoubtedly have explicit difference. This is the important truth which the criticism I have retailed has succeeded in bringing to light. But before there is difference, or because there is difference, there must be unity as the background or starting-point of judgment. To deny this and to seek for the starting-point in judgment itself, is like identifying an organism with the process by which its parts become differentiated instead of with the living embryo. It is true that this unanalysed unity is something less than concrete thought, inasmuch as its differences as well as its unity have not yet been made explicit. Yet just as the embryo while undoubtedly less than what it is on the point of developing into, yet in a sense is more in containing the promise of yet further changes, so this first implicit unity is more than the movements of concrete thought, in that it already contains implicitly all that it is the aim of these movements to make explicit and intelligible. ${ }^{1}$

1 For hints upon this way of stating the case I am indebted to an unpublished paper by Professor J. S. Mackenzie. 
Here, then, is our result so far. It is a mistake to look for a prius of judgment in the explicit elements distinguishable within it. But this cannot mean that judgments hang in a vacuum, or are begotten by spontaneous generation out of nothing. Granted a judgment is a movement of analysis and synthesis, there must be something which is analysed and which reappears in the result in a new and, let us say, more determinate form. The question is, How are we to conceive of this something? From the side of metaphysics this is easily enough answered. Mr. Bradley would say that it is reality. Reality, he says, is the subject of all judgment. I have no quarrel with this statement. I wish merely to consider what it implies for logic. Reality cannot be (Mr. Bradley cannot intend it to be) something other than a form of experience. All reality is experience. It is, however, an experience as yet undifferentiated in respect to the particular subject and predicate of the judgment which is on the point of being made. Relatively to that judgment it is a prius: It exists before and it survives the judgment. For judgment is in its nature finite. It is a definition of reality. Reality, on the contrary, is in its nature infinite. It refuses to be defined or contained in any predicate. We try to exhaust it by enclosing it in the predieate, or, if you please, in the subject and predicate. We hope we have succeeded. Judgment raises our hopes. It promises us success. It says $\mathrm{A}$ is $\mathrm{B}$. But we know all the time that we have failed. In the very act of judging the reality has escaped us. We have done something. We have made part of it our own. But a part, by far the greater part, still wavers as a phantom before us. 
This is recognised in the case of the reality which we are said to perceive. This, we are told, is concrete, while our thoughts about it are abstract. It is somehow given as a whole. Our judgments, on the other hand, are partial. They are about it and about.

“Thought may take perception's place,

But hardly coexists in any case

Being its mere presentiment—of the whole

By parts, the simultaneous and the sole

By the successive and the many."

But the same is true of realities we cannot properly be said to perceive: the hyperbola, the Reformation, the human mind. Here, too, there is always a beyond which we have failed to grasp and which tempts us to try again.

"Man knows partly and conceives besides, Creeps ever on from fancies to the fact, And in this striving, this converting air Into a solid he may grasp and use, Finds progress."

What are we to call this element in our experience? Psychology does not give us much aid here. It is concerned with the origin and growth of our subjective states and considers its work to be done when it refers us to an "undifferentiated continuum" as their common matrix. But in logic we have nothing to do with the origin and growth of psychical states. We have to do with the mind's content in its objective nature as our "world"; and the question I have suggested is, How are we to name that world at the stage at which it has not yet appeared as definitely determined by the contents of the judgment?

If we turn for an answer to the usages of popular language, they leave us in no doubt. We say we have 
a "notion" of a thing, though we cannot describe it, that it is indescribable, or (after we have heard it described) that we have a better notion of it than before. Again, we say of scientific or other eccentric persons that they have "notions" of their own which we conceive of as obscure movements of their minds which they have not imparted to anyone and have not even made clear to themselves. What popular language calls " notion," I should propose, following Hegel, to call "concept." I am prepared, of course, to admit that this usage seems at first sight to differ from that with which English logicians have made us familiar. In a sense it seems even to contrast with it. According to the traditional use, the concept is the group of predicates by which we have defined a thing. The concept of gold is hard, yellow, bright, untarnishable metal. According to the use here suggested, it is just the opposite: it is that element in our consciousness of the thing which is not yet defined by any predicates, but remains over after we have done our best, as an unmanageable surd. The contrast may be made even more striking by a reference to the traditional doctrine of the proposition. Traditional logic analyses the proposition into subject, predicate, and copula. It looks for the concept in the two former elements and passes over the copula as a mere connecting link between them. According to the above view, it is required of the new logic that it shall reverse this treatment and look for the concept no longer in the determinate elements which the judgment exhibits, but in the indeterminate "is" which it has sometimes" been paradoxically maintained constitutes the true subject or starting-point of the judgment. Yet, in

${ }^{1}$ Cp. Professor Jones's Philosophy of Lotze, p. 359. 
spite of this apparent contrast, there are advantages in the proposed terminology which will presently appear. Meantime two questions remain: Does the concept in the sense just defined really enter into logical doctrine at all ? Granting that it does, is there anything to be said about it that would not be better said under the heads of judgment and inference?

\section{III.}

1. The former of these questions must be answered by asking another: How are we to conceive of logic? Is it the account of the mode in which true judgments are formed about a reality which is given independently of them? Or is it the account of the steps by which reality itself develops in the individual mind?

The first of these views is that which was made current by the material logicians of the last generation. It assumes that we have reality on the one side as something given as independently of our judgments abont it, and judgment and inference, as merely ways of arranging our ideas about it, on the other. According to this view, the science of true judgments and the science of reality about which the judgments are made fall apart-the one is called logic, the other metaphysics. The latter is that which has to do with the concept in the sense above described, while logic is only concerned with the traditional concepts and with judgments and inferences which are formed out of them or, again, which go to form them. With this view we are not here concerned. Those who still hold it are not likely to admit that there is any suitability in describing the reality about which we form concepts as itself a concept.

But it is different with the present generation of 
English logicians. They no longer start with a separation between knowledge and reality. Reality is already present in the earliest form of experience. "Reality," says Dr. Bosanquet," "is given for me in present sensuous perception and in the immediate feeling of my own sentient existence that goes with it." This cannot be too strongly emphasised. Reality is given from the first or not given at all. Your America is here or nowhere. The kingdom of truth, like the kingdom of heaven, is within you. Plato said its development was a process of remembering of what we knew before. This is a myth, but it has a meaning, and its meaning is that knowledge is the progressive unfolding of an objective world which is already present in idea. How are we to conceive of this idea? It is here that I wish the new school of logicians to be more explicit. Dr. Bosanquet wishes us to conceive of it as judgment. Reality, he says with Hegel, is a judgment. But Hegel is also identified with the doctrine of the notion, and I have been trying to show that there is no gain, but a loss to logic in dispensing with it. To do so leaves the judgment as a piece of lifeless mechanism on our hands. The judgment is a movement, but what moves in it? The mind certainly moves, but only with it. What moves in it is reality itself.

But if this be so, why, it may be asked, not say so? Why introduce confusion by baptising this reality as concept? For several reasons. First, because reality is experience, and by calling it concept we secure that truth in the rear. Secondly, the new usage is not so far removed from the old as might appear. The concept is reality regarded as the principle of movement

${ }^{1}$ Logic, vol. i. p. 77. 
and progress in the mind's experience. But reality is never present as a whole. It is always at some particular point that reality makes itself felt. Knowledge never grows as a whole; it grows at some particular point. This point is what we call the subject of thought-the topic of conversation, exposition, or what not. And this in turn is never present in its totality, but is developed in successive steps corresponding to separate heads, and ultimately to the subjects of separate sentences. These, if we like to say so, "symbolise" the topic or area of reality with which we are dealing; and this, again, symbolises reality as a whole, but they do so, not as something different from it, but as the determinate forms it assumes in virtue of the constitution of the human mind as a finite organism.

Dr. Stout has done good service in illustrating the relation between subject and predicate, as ordinarily understood, from the relation between the "subject" of conversation and the series of judgments through which it is advanced. The grammatical subject he conceives of as the rest of the foot on the ground in walking, the act of judgment as the forward movement executed from it. His whole account, as well as the doctrine of apperception with which it is connected, may be taken as giving us the psychology of this process. But while psychology is concerned with the fact and the way it comes about, it has nothing to do with the reason of it. It leaves this to logic, and it seems surprising that the logic of apperception is still to seek. The doctrine of the concept would fill this gap. In such a doctrine the dominant apperceptive group would appear, not merely as a natura naturata with an origin in time and again operative 
in directing the succession of mental states, but as a natura naturans-the point at which reality as an objective system is operative in the individual mind. All that modern psychology has to say about the way in which these groups act in appropriating new material from the data of sense is of course welcome to the logician, but it leaves the question of what it is that makes the appropriation, and why it makes it, unanswered. This it would be the aim of the logician in the doctrine of the concept to set forth. He would show (to return to Dr. Stout's metaphor) that what moves in the judgment is the subject itself. The argument we say "advances," the subject "moves on," and as it moves it "develops." Reality becomes richer and more coherent at the point indicated by the subject. If it be said that this is a strained and exaggerated account of what takes place in ordinary thinking-such movement being the exception and not the rule, since most people's notions are stereotyped-this is to forget that wherever there is mind at all there are interests, and that these interests represent the points at which reality is on the growing hand. Where, on the contrary, there are no interests the mind's world is on the wane, reality is on the point of deserting it, and leaving it to imbecility or death.

2. The second of the above questions has already been answered by implication in what has just been said. If the aim of logic be to give an account of the development of reality in the individual mind, it is surely a fundamental part of it to give some account of the points from which it may start. This would not, of course; mean that we are to begin as the traditional logic exhorts us to do, with an enumeration 
of the different kinds of concepts on which popular language has accidentally stumbled. We have already seen how such an enumeration of the "elements of judgment" is an anachronism. It would mean that after making clear that what we intend by the "concept" is the form which reality as an intellectual possession assumes in the individual mind and thus distinguishing it from the ideal of gooduess on the one hand, and beauty on the other (the subject-matter of ethics and æsthetics), we should go on to attempt to delineate the stages through which it passes in its progress towards complete transparency and coherence.

If the reader desires an illustration of what is meant by such a delineation he will find one in Sigwart's account of the different meanings that may be assigned to the term concept. In a passage towards the beginning of the Logic ${ }^{1}$ Sigwart distinguishes, (1) the psychological concept-the first rude image of reality at the stage at which by acquiring generality it has become qualified to take its place as an element of judgment, (2) the logical concept-the idea with its meaning fixed and clearly determined, (3) the metaphysical concept the adequate copy of the essence of things. In the last sense we speak of the concept of life which would be the keystone of physiology, the . concept of matter which would do the same for chemistry and physics, of mind for psychology, and, as Hegel would remind us, of freedom for history and ethics. After making these distinctions, Sigwart dismisses the concept in the first and the third sense from logic, and proposes to confine himself to the second. But this is a quite arbitrary concession to the older logic. The best that can be said for Sigwart

1 English Translation, vol. i. p. 245. 
is that in the sequel he does not confine himself with any strictness to the limits he here lays down. On the above interpretation of the meaning of the concept these three are not different senses in which concept may be taken, but show themselves at once as only different stages in the development of the concept in the individual mind. First it appears with all the irrelevancies of our particular experience. The universal is concealed by the particularity of the form under which it appears. Next we have the working definitions of science. The concept has been sufficiently purified of irrelevancies to serve for purposes of accurate thought and as a starting-point for scientific treatment. Lastly, it is passed through the retort of observation and analysis and developed into that completely coherent and transparent system which we call the scientific notion of the thing. ${ }^{1}$

All this, however, would be matter of detail into which I an not here called upon to go. The object of this paper will have been sufficiently served if it has suggested, as the finishing touch required by the splendid work of reconstruction on which English logicians have recently been engaged, the explicit recognition: (1) That logic rightly understood is the science of the forms which reality, as an intellectual possession, assumes as it develops in the individual mind. (2) That this "reality, as an intellectual possession," is what ordinary people understand by notion, and, however we, as logicians, choose to denominate it, must be regarded as prior to judgment not as bricks and mortar are prior to the house, nor

1 These three stages correspond on the whole to Hegel's abstract particular, abstract universal, and individual, which again are roughly the singular, the general or abstract, and the universal of modern logic. 
even as the seed is prior to the plant, but as the soul is prior to the body, or as the consciousness of will and personality are prior to the actions by which we try to express them.

IV.

Since writing the above I have read Mr. L. T. Hobhouse's interesting chapter on "Simple Apprehension," at the beginning of his recently published work on the Theory of Knowledge. With Mr. Hobhouse's conclusions I find myself in general in hearty sympathy, and already owe so much to his book that I am loath to quarrel with any part of it. But it may serve to bring into prominence the point $I$ have striven to make if I compare it with the view for which Mr. Hobhouse there contends.

Against Green's view that the apprehended content is constituted by the synthetic activity of thought and that all knowledge is of relations, Mr. Hobhouse holds with James that before we can relate there must be something which can be related, that "judgments themselves would have no meaning if they did not refer to the data as apprehended," and accordingly that the primary act of knowledge is not a judgment, but a simple apprehension.

The view here stated seems at first sight to bear a close resemblance to that for which I have contended, the only difference being that where I speak of "concept" Mr. Hobhouse prefers to speak of "content of apprehension." In reality it differs from it in two important respects :-

1. Mr. Hobhouse, adopting the phraseology to which Mr. Bradley has given some countenance, speaks of the sensation or content of apprehension as the point at which we are "in closest contact with reality." The 
immediate effect of this is to force him to conceive, with Mr. Bradley, of the act of apprehension as a reference of content to reality. But this is to expose himself at once to the argument which recent logic has directed against Lotze's attempt to distinguish judgment from concept. Mr. Hobhouse seems quite conscious of the difficulty, and proposes to meet it by calling apprehension an "assertion" (p. 19) and its content "fact." But this only throws us a step further back. What is an assertion wherein nothing is asserted? And if something is asserted, wherein does an assertion differ from a judgment? And again, what is fact if it is not the content of a judgment?

To incriminate Mr. Hobhouse is not, however, to exculpate myself, and it still remains to show that this difficulty does not attach to the view that has been taken above of the logical prius of judgment. This, we have seen, is idea, and it is also reality. But how, it may be asked, can it be idea, unless it has identity, and how can it have identity without having difference? And these imply judgment. Again, how can it have reality unless it be taken for it or referred to it? And so to take it or refer it is again judgment.

To the first point I reply that the concept for which I contend is a region of experience into which identity and difference (and therefore judgment) have not yet penetrated, and to the second that it is just this "reference of the idea" as a subjective content to reality as objective that I find so incomprehensible. The terms in which the doctrine is stated seem to me to be derived from the older view of the nature of judgment as predicating one concept of another. It suggests that we have first an idea as a species of unsigned cheque, and that we then proceed to attach the signa- 
ture of reality as of another and different kind of idea to it. This, of course, is mythology. ${ }^{1}$ It is better frankly to regard the concept as that which develops in the judgment, as the unity of the content and reality -a unity which, as we have already seen, is symbolised in the ordinary analysis of the proposition not by the subject, nor even by the subject + the predicate, but by the copula.

2. The second point of distinction may be stated in a word. The datum or starting-point on $\mathrm{Mr}$. Hobhouse's view is the content which is attended to. $\mathrm{He}$ admits, of course, that there is a margin as well as a focus of attention. But this margin he treats, with the psychologist, as something beside the content and irrelevant to it. The point which is important for logic, conceived of as the science of the steps by which reality develops in the individual mind (and this, as I understand him, is the way in which Mr. Hobhouse conceives of it), is thus obscured. Reality is thus after all conceived of as beginning for us in that most attenuated and impotent of all its forms-the mere isolated sensation, and we are left to look for the principle of the whole movement which Mr. Hobhouse is about to describe among the abstractions of psychology - for the living among the dead. The view above taken insists, on the contrary, that the starting-point for logic is not the mere sensation, but the sensation

1 It is curious that Professor James should be one of the most ardent opponents of this view, and yet should fail to see that in rejecting it he implicitly admits at least one part of the "intellectualist" contention that our primitire experiences are already "thoughts." Mr. Hobhouse's polemic against Green possesses this great merit as compared with Professor James's, that in naming the terminus a quo of thought "assertion" instead of "sensation," he acknowledges this truth. 
upon the background of the concept, of which it represents only the first stirrings in the individual mind.

I shall bring these differences to a point. $\mathrm{Mr}$. Hobhouse says, "We maintain that apprehension is a distinct factor postulated as a condition by judgments of perception, and that its content is a distinct part within the more complex whole which judgment asserts" (p. 28). I have replied first that this merely reopens a controversy which ought by this time to be taken as closed $;^{1}$ and, secondly, that it gives no logical rationale of the movement we call thought. I should therefore propose to amend the above statement by maintaining that the starting-point is not "a distinct part within the more complex whole which the judgment asserts," but an indeterminate complex within which judgment moves as the process whereby its contents are first resolved into relative simplicity and then reassimilated as parts or elements of a determinate whole.

1 Mr. Hobhouse himself, in his chapters on "Ideas" (chaps. vi. and vii.), seems so to take it. 


\section{II.}

\section{THE GOAL OF KNOWLEDGE.}

T PROPOSE to discuss three questions in this paper, 1 the first two very shortly, the third at greater length. First, under what form ought we to conceive of the goal or ideal of knowledge? Secondly, how does this ideal operate in actual experience? And thirdly, what is its relation to ultimate reality?

I.

What in general outline is the nature of the ideal which we set before ourselves in knowledge? In attempting an answer to this question I may begin by referring to the contents of the previous paper. I there tried to show that the beginnings of knowledge must be looked for in a concept or form of apprehension which, like the undifferentiated continuum of the psychologist, may be said to contain in itself the possibility of all differences, but to hold them as yet in solution, awaiting the distinguishing, crystallising action of the logical judgment to give them at once a separate place and coherent connexion in the whole. Following this suggestion, we may describe the end of knowledge as a concept or mode of apprehending the world in which, as in the developed organism, the processes of differentiation and integration have been brought to completion in a fully articulated system of coherent judgments. 
This, if you like, is a metaphor, but it points to the two most important characteristics which logic must recognise as belonging to fully developed knowledgeall-inclusiveness and self-consistency. We seek in the first place to know all that is to be known about a thing - or about the world. The original subjectconcept becomes differentiated in a number of predicateconcepts. Or, to express the same thing in terms of judgment, the judgment which predicates mere existence of a something to be known is extended into a system of judgments which tell us what is to be known about it. But, secondly, we seek to understand what we have learned, to connect one predicate-concept with another. Ordinary experience brings with it the conviction, not only of its own poverty as compared with the infinite riches of the world, but of its own inward discordancy as compared with a vision of harmony and ultimate transparency-a transparency which for logic must consist in the consistency and coherence of the judgments which we are forced to make upon reality as it comes before us in ordinary sense-perception and in the processes of scientific investigation. Knowledge may thus be said to aim in the first place at its own expansion. It seeks to embrace reality in all its parts or details. It aims in the second place at explanation. It seeks to understand the relation of the parts to one another, and to the whole to which they belong. Its ideal may thus be schematised as a whole of clear and distinct parts related to one another in such a way that the mind can pass from any one along the lines of judgment and inference to any other, with the result that the whole is seen to be reflected into every part, and every part to contain the whole.

Whether the world can ever thus be reduced to 
complete transparency is a question with which we need not trouble ourselves at present; it is sufficient to note not only that all science proceeds upon the assumption that it can, but that those sciences which are most advanced, and which as "deductive" are commonly taken as the types of completeness and certainty, really do to a certain extent exhibit these characteristics. Thus geometry aims in the first place at exhausting and in the second place at proving the interconnexion of the properties of the figures with which it deals, and it would not be difficult to throw the knowledge we derive from it as to any particular figure, e.g. the triangle, into a form which would exhibit the properties of the figure as such and of each of the separate species of it (if it has species) as necessary deductions from its own nature and as thus inherently related to one another through their common relation to the whole whose properties they are.

II.

Without stopping to dwell upon this, ${ }^{1}$ we may go on to notice in the second place the mode in which the ideal under these two aspects of all-embraciveness and complete consistency operates in actual experience.

The question deserves more careful consideration than I can here afford to give it, but I must not pass it wholly over. The answer in general is that it operates like any other ideal. The dynamical efficiency of an idea, that which transforms it from a mere idea in the mind into an end or an ideal, is the felt discord between it and the actually existing fact. In his little book on the Psychology of the Moral Self, Dr. Bosanquet

1 For fuller details see the excellent sections in HobHouse's Theory of Knowledge, part iii. chap. vi. init. 
has some observations on the question how our ideas can include not only facts but purposes, which may assist us here. He points out that they can become purposes by being recognised as only conditionally true. A purpose is always relative to actual facts; an ideal is always based upon some reality. It stands to that reality as an appercipient group (e.g. the group corresponding to a penknife) does to the actual presentation (e.g. the penknife in my desk). The ideal is only realised when the actual thing comes up to the idea of it. My penknife is rather a broken-down affair; until I have it cleaned up and sharpened my idea is only conditionally true. Facing the penknife as it is, there is the idea of what the penknife ought to be ready when the contrast becomes too painful to rise into an actual purpose to take it to the cutler or replace it with a new one. Before turning to the question before us we may notice that while the above mode of expression is undoubtedly the right one from the point of view of psychology, from the point of view of teleology we may prefer to reverse it. Here we have to recognise that the ideal is the truth of the actual. The source of dissatisfaction, and therefore of action, is that the actual is not true. It fails of truth and reality because it falls short of the features that the persistent idea or appercipient system contains. The reality of the knife is its suitability to its purpose; so far as it is unsuitable it fails to be a knife. In taking it to the cutler's I restore this reality to it.

Applying this to the ideal of knowledge, the actual fact here, of course, is a concept or group of concepts ; the persistent idea is the idea of these concepts rendered internally harmonious in the manner we have described. This ideal asserts itself against the actual, forcing us 
to realise that it is only conditionally true, that it can only become so as we bring our actual concepts into harmony with it; or (as we have preferred to express it) that our actual concepts are not really true and real at all, and can only become so by having their nature so altered as to conform to the ideal. This alteration, we have seen, takes place in two directions - that of extension and that of coherence; and this twofold character is emphasised in the history of mind by the alternation of periods of specialisation in which facts are accumulated with periods of speculation in which they are harmonised and explained.

This tendency of these two sides to fall apart in actual life has led some writers to represent them as not merely different, but actually opposed to each other and requiring to be harmonised by a kind of compromise. ${ }^{1}$ But these are not two different ideals, but different sides of one and the same. In any genuine piece of scientific research the accumulation of facts is always controlled by unifying intelligence. In the pursuit of knowledge the human mind cannot really go on adding fact to fact without some effort after inner organisation, any more than in the pursuit of happiness it can go out to new objects of interest without some attempt at co-ordinating them with the old. On the other hand, just as the instability of a life which is founded on too narrow a principle, e.g. money-getting, is the source of moral progress in individuals and nations, forcing them in a crisis to recognise that there is more in life than their philosophy has dreamed of, so it is the continual development of contradictions within the unity which

1 See JAMEs, in his recently published volume, The Will to Believe, essay on the "Sentiment of Rationality," p. 65 foll. 
our thought has already established among the facts that drives it on to a more comprehensive view, and, as Mr. Bradley says, compels it to take the road of indefinite expansion. All this will be clearer presently, when we go on to discuss the relation of this formal account of the goal of knowledge to the concrete reality. Meantime an example, taken almost at random, may assist us to understand how fact and theory act and react on each other in these respects.

When Professor Seeley, in his posthumous work on the History of British Diplomacy, proceeds to examine the character of the fact we know as the English Revolution, he finds the usual account of it which attributes an important and all-pervasive change to the insignificant cause of the private character of James II. and his personal friendship with Louis XIV. altogether inadequate. To explain this apparent contradiction he asks us to go beyond the limits of the fact as an event in English history, and to connect it with the larger whole of which it is only a part, viz. the European movement of the time, in which the forces of the counter-Reformation are headed by Louis XIV., while Protestantism is represented by William of Orange. From this point of view the English Revolution appears no longer as a constitutional change taking place in a corner of Europe, caused by a petty quarrel between a Stuart and his Parliament, but as an important episode in a great drama, of which the chief actors are the greatest sovereign and the greatest politician and patriot of his time. By the explanation in which Seeley asks us to follow him, our knowledge is not only made more coherent; in being made more coherent it has been made fuller. The fact reflects more of the history of the world and has thus been 
expanded and deepened. On the other hand, every new fact we discover about a thing is a step in the direction of its explanation, for this fact on closer inspection is seen to contain a relation to other things, and thus to force us beyond the limits of the part to the whole to which it belongs and which alone can make it intelligible to us. In this way a new stage in our investigation is reached, when we notice that the English Revolution is not merely a political and religious movement: it coincides with the Union of England and Scotland, the foundation of the Bank of England and the institution of the National Debt. These "facts" at once suggest a connexion with the industrial condition of the world at the time, and thus lead the way to a more comprehensive theory still of the phenomenon to which they belong as adjectives.

III.

The goal of knowledge, then, is a system of judgments or concepts connected in such a manner as enables us to go from any one to any other in virtue of their perceived coherence in the whole. But such a system, if we could suppose it embodied in an encyclopædic treatise, would be of no interest to us except in so far as it stands related to the everyday world of our experience. We are interested, if we might say 1 so, not in science, but in the things with which science deals; thought and knowledge, as Mill reminds us, proceed from "particulars to particulars." Our aim is to realise the thing, and the question occurs whether such a system of concepts as I have described, if it ( were worked out to completion, would put us in possession of the actual world as it is-concrete, real and individual. 
The view that underlies much of the popular logic, and is tacitly admitted in some of the older accounts of the work of thought and knowledge, tends to separate between the ideal of science and the concrete individual thing. According to this view, thought starts from the concrete reality. Its function is to "abstract" from it, and in doing so to turn its back upon the thing itself. Science and philosophy, it is implied, are well enough, but people who would keep a level head on their shoulders must ever return from these abstractions to the concrete data of sense as the only test of reality. Similarly from the side of individuality. The individual thing or event is supposed to be given within the four corners of its existence as a particular here and now. Thought has nothing to do with its internal constitution as a particular thing; its function, on the contrary, is to go beyond it and connect it from the outside with other things that resemble it in some isolated respect-in other words, to generalise it. In this process the thing itself is supposed to remain as it was before; it is merely set in a new group and viewed in connection with other things. By means of such groupings intellectual processes are simplified, but there has been no real change in our idea of the thing itself, or if there has, it is rather for the worse. Its individuality, instead of being developed, tends to be obscured: to regain it we have to turn our back again on the abstractions of thought, i.e. on the arbitrary relations we have established between it and other things, and view it in the "solid singleness" of its concrete existence.

It is hardly necessary at this time of day to say much to discredit this view of the function of thought and the relation of its ideal to reality. Most philo- 
sophers now admit within limits that thought has a constitutive as well as a merely formal function with regard to reality. It is admitted, for instance, that in going beyond the thing or the fact, as we are forced to do in endeavouring to understand it, we are not leaving its individuality behind, but carrying it along with us and raising it at each stage of our explanation to a higher power. ${ }^{1}$ To revert to the above illustration. To bury ourselves in Professor Seeley's theories is not to allow the English Revolution as a concrete event to fade away in generality, but to give it for the first time the clear outlines of a distinct and unique event. Similarly from the side of reality. We start, of course, from an existing thing or event, but its existence in time and space is only an element in its reality. Apart from its what and its why, the hold, so to speak, which we have upon its reality is but a feeble one. In developing our thoughts about it we are not abstracting from its reality or leaving anything behind which is worth having. Instead of being cancelled in the intellectual process, all that it had of reality at the outset is taken up and developed into a higher form. For reality means significance, and the significance of a thing or event is only known when the latter has become to us what his crystal is to the magician, "the ball that irnages the world," and we see reflected in it as in a transparent focus the characters of the whole to which it belongs.

But a further question rises when we ask not whether thought has any constitutive function in

1 Yet the view in question dies hard. See JAMEs, loc. cit. It is the exact parallel in logic to the theory of some people in practice, that education and culture make against individuality of character. See above, "Abstract and Practical Ethics." 
building up the world of knowledge, but what is the relation of the ideal of knowledge itself to ultimate reality. Can the world we know ever really be the world as it is in itself? We have all been made familiar in these days with the doctrine of degrees of reality, and we have, I suppose, all accepted it so far as to admit that experience stands at different levels according to the degree in which it corresponds to the ideal above described of an experience which is allembracive and completely harmonious. But let us now suppose that this ideal is completely realised, so far as knowledge is concerned, in a system of concepts which exhausts the contents of the world, and is internally harmonious. Would such a system express reality as it is? would it be the absolute? or does it necessarily fail to express the truth, and must it be at last condemned as mere appearance? The conclusions of recent English philosophy, as is well known, favour the latter alternative, and require to be squarely faced by any one who, like the present writer, holds an opposite view.

The question itself, it will be admitted, is of sufficient importance to attract more attention than it has hitherto received ${ }^{1}$ from philosophers. It is not only the preconceptions of ordinary common sense, but the central doctrine of the current form of speculative idealism that is called in question. Common-sense people never doubt not only that the more they know of the world the firmer the hold they obtain of reality, but that if they knew all that it is possible to know they would be as God and know reality as it is. Or, to put it in the form suggested by our former discussion, they never

1 Since this was written Prof. ANDrew SETH's book, Man's Place in the Cosmos, has appeared. It has enabled me to shorten my argument. 
doubt that reality is somehow given in their concept of the world, and that all they have to do is to fill that out and bring it into harmony with itself. Idealist philosophy, moreover, has until recently acquiesced in this view, and in its doctrine of the Absolute has done little more than translate it into the language of the Schools. It is sufficiently disquieting to be asked to change all this, and before giving in our adhesion to the newer theory we may be excused for desiring to examine it a little more closely than has hitherto, I think, been done from the point of view of the presuppositions of Idealism itself.

It is hardly necessary in an article like the present to state the grounds upon which the incompatibility of the form of knowledge with ultimate reality is based by the writers who maintain it. I shall condense them into the two arguments that have commended themselves to two distinguished writers. In the first place it is maintained that knowledge is not the only form of reality. Besides knowledge there is feeling, and perhaps volition. As Mr. Bradley puts it:-

"Let us imagine a harmonious system of ideal content united by relations and reflecting itself in self-conscious harmony. This is to be reality, all reality, and there is nothing outside it. The delights and pains of the flesh, the agonies and raptures of the soul-these are fragmentary meteors fallen from thought's harmonious system. But these burning experiences, how in any sense can they be mere pieces of thought's heaven? For if the fall is real there is a world outside thought's region, and if the fall is apparent then human error itself is not included there. Heaven, in brief, must either not be heaven or else not all reality." 1

1 Appearance and Reality, 2nd ed., p. 170 foll. ; cp. McTaggarT's Studies in Hegetian Dialectic, p. 214 foll. 
The conclusion is, knowledge can never be a complete expression of the whole of reality. But secondly, the ideal of knowledge makes a demand which, if it were satisfied, would be the destruction of one side or the other of the antithesis upon which knowlege itself depends. "If thought were successful it would have a predicate consistent in itself, and agreeing entirely with the subject. But, on the other hand, the predicate must be always ideal. It must, that is, be a 'what' not in unity with its own 'that,' and therefore, in and by itself, devoid of existence." If, on the other hand, it were to include existence, it would not be thought any longer. "It would have passed into another and a higher reality." 1 To the conclusion therefore that knowledge cannot be the full expression of reality, we must add that it cannot even form an element in the ultimate reality.

With regard to these arguments the first thing to be noticed is that they do not go on all fours. The first is directed against the position that knowledge is all reality, the second against the position that knowledge is an element in reality-the first is concerned with what we might call the ideal of consciousness, only the second with the ideal of knowledge as such.

It is admitted on all hands that the ultimate form of experience cannot be exhaustively described in terms of the goal of the scientific or speculative reason. The history of Idealist thought may indeed be said to consist of the successive steps by which philosophy has arrived at the recognition of this truth. Starting from the acknowledgment that reality is to be sought for in the field of Ideas, it is possible to describe these ideas (perhaps Plato sometimes did so) as intelligible essences

1 Bradley, p. 162 foll.; cp. McTaggart, p. 208 foll. 
unrelated to the concrete life of ordinary feeling and action. Going on from this it is a second step (a step which it was Aristotle's merit to make) to have shown that the supreme end of the soul as compared with the end or ideal of the speculative intelligence is the rational or intelligent life; that the truth for which our souls long is not an abstract system of ideas, but a truth which shall harmonise and enrich our lives-a truth that shall make us free. Finally it is realised (and this, I suppose, was the characteristic contribution of Christian thought) that the Ideas which constitute reality have not only to be grasped in the thought and realised in life; they have to be loved and adored as the supreme objects of feeling. This is the truth which, I take it, Hegel meant to express, with whatever success, ${ }^{1}$ in his well-known doctrine that the highest expression of spirit is a form of consciousness, which, under whatever name (he called it Philosophy), must be conceived of as including art, morality, and religion. But to admit that the highest form of experience must be one in which somehow these three elements of thought, volition, and feeling must be included is one thing; to maintain that it must be one in which the peculiar nature of any one of them must be cancelled is quite another. What we know of them in ordinary conscious experience rather supports the opposite conclusion, for as it is admitted that knowledge, apart from feeling and volition, is a nonentity, it is equally clear that feeling and volition, apart from the experience of a soul which is cognitive in the sense in which we commonly understand cognition, are inconceivable.

1 Jowett thought he failed: "The problem of $\alpha \lambda \eta^{\prime} \theta \epsilon \iota a \pi \rho \alpha \kappa \iota \kappa \eta^{\prime}$, truth idealised and set in aetion, he does not seem to me to have solved; the Gospel of St. John does" (Life and Letters, vol. i. p. 92). 
The second argument, however, deals directly with the question on hand, and is a more serious matter. It takes two forms, which we may state briefly as follows: The object of knowledge presents itself to us with the two characteristics of infinitude and immediacy. Knowledge seeks to exhaust this infinitude in a series of finite predicates, and at the same time to substitute for the immediacy of the percept the mediated necessity of a logical system. Its ideal is thus the unity of thought with reality, of subject with reality. Now let us suppose this ideal realised, what has happened? From the side of the thing we may be said to have completely idealised our object, but in doing so we have destroyed it, for it has in the process passed over to the side of idea. Similarly from the side of knowledge and idea: we have established the unity of subject with object, but it is no longer the unity of knowledge, for this demands the antithesis of thought and thing, and this antithesis has been destroyed. To this argument, based upon the contradiction involved in the conception of the ideal of knowledge as the unity of subject and object, is added another based upon the conception of the ideal as the complete individualisation of the object. Knowledge aims at the complete differentiation of the object, but as the instrument with which it works is always the abstract predicate, it necessarily fails to do justice to the contents which it endeavours to express, and the true individuality of the object falls outside the system of our predicates. As Mr. McTaggart puts it:-

"The fact that the object is more or less independent as against us-and without some independence knowledge would be impossible... - -renders it certain that every 
object has an individual unity to some extent. Now knowledge fails to give this unity its rights. The meaning of the object is found in its This, and its This is, to knowledge, something alien. Knowledge sees it to be, in a sense, the centre of the object, but only a dead centre, a mere residuum produced by abstracting all possible predicates, not a living and unifying centre, such as we know that the synthetic unity of apperception is to our own lives which we have the advantage of seeing from inside. And since it thus views it from a standpoint which is merely external, knowledge can never represent the object so faithfully as to attain its own ideal." 1

Let us be quite clear as to what it is in the above arguments that concerns us. We are not concerned with the question as to whether the ideal of complete knowledge is for us a possibility. To know completely the flower in the crannied wall, we must know the whole world besides, and this we may admit is and must remain for us an ideal. The question is whether the ideal is itself "ruined" by an inner contradiction. The above arguments are put forward to prove that it is by showing that both from the side of unity and diversity in realising its ideal knowledge must commit suicide.

Now we may at once admit that this conclusion follows from the assumptions as to the nature of the unity and the diversity demanded by the ideal of knowledge on which both these arguments are based. Thus if, as is assumed in the former argument, the unity at which knowledge aims is one which is incompatible with the difference of subject and object, it follows, of course, that the attainment of the unity would involve the destruction of difference, and with

1 Studies in Hegelian Dialectic, § 198. 
it the ruin of knowledge as such. Similarly if we begin by assuming with Mr. McTaggart that the individuality of which we are in search is contained in something other than thought, it must of course remain so to the end so far as thought and knowledge are concerned. The ideal of thought is to think everything, but if everything is precluded by its nature as thing from entering into thought, then-well then by its nature it must be left out. But there is surely the prior question-which on so important a matter might be worth asking - whether the unity and the differentiation which form the twofold aspect of the ideal are really of the nature supposed.

With regard to the former of these points it is admitted, of course, that all knowledge is a process of unification: all judgment is synthetic. But it is equally of the essence of knowledge to be the unification of differences: all judgment qua judgment is analytic. Finally, in being the one it is also the other. We are not to say judgment is synthetic and analytic; it being synthetic it is analytic. We cannot have the unity except at the price of the difference and vice versâ. And what holds of judgment in general holds in particular of the primary judgment which separates between subject and object, and gives knowledge the form it wears to the ordinary consciousness of the attempt to comprehend by means of finite predicates the nature of a being which is essentially infinite and incomprehensible. It is impossible to suppose that Mr. Bradley intends to deny this, which one would have thought is an axiom of modern idealism. Yet, in arguing that the form of knowledge is incompatible with ultimate reality, he seems to proceed throughout upon the assumption that the unity which 
the ideal of knowledge requires is one which is incompatible with the difference of subject and object. One consequence of this is that he tends to represent the differences as something comparatively accidental and irrelevant. They are a "disease" which breaks out in the object of knowledge, and has, as he tells us, to be healed homœopathically. ${ }^{1}$ Or again they are a "dissection " ${ }^{2}$ they give us the anatomy of the thing, but never the living thing itself. The life of the object falls on the side of the unity. In all this we are tempted to ask whether Mr. Bradley has not been carried away by his own metaphor, and whether if we changed the metaphor we might not arrive at a precisely opposite conclusion. Let the differences be the living functions of the organism instead of dead sections of it, and what becomes of the unity? In this case the "life" falls on the side of the predicates, and leaves us only the stillness of death as the unity out of which they come and to which they return. This, indeed, as we shall see, is very much the conclusion at which Mr. McTaggart, approaching the question from the side of the differences, actually arrives when he finds in the "this" of the thing a mere dead centre which is left on our hands when we abstract from the predicates which give life and individuality to the object as an element in our knowledge.

I do not propose to dwell further on Mr. Bradley's argument, but refer the reader to Professor Seth's treatment of it (op. cit.), with which I find myself in substantial agreement. I quote his conclusion as my own: "Dissatisfaction with the form of knowledge as such seems to me, I must confess, chimerical; and I am sure that the repudiation of it leads not to

1 Appearance and Reality, p. 166.

2 Ibid., p. 167. 
any higher unity, but to the pit of undifferentiated substance out of which Hegel dug philosophy." It will be more profitable if, approaching the question from the side of differentiation, I try to show from a point of view which Professor Seth would perhaps not accept that the argument of which $I$ have taken Mr. McTaggart as the representative is open to a similar criticism.

As Mr. Bradley assumes that the unity of which knowledge is in search is incompatible with its differences, Mr. McTaggart conversely assumes that the differences by which we seek to know the thing are incompatible with its unity. To know the thing we must know it in its abstract unity, the thisness which excludes its being this or that. But is not this simply to turn one's back on the most important lesson that philosophy since Kant has been endeavouring to teach, the distinction between the abstract and the concrete particular? This distinction is too familiar to dwell upon. For the present argument it means that "this" may be taken in a more abstract or in a more concrete sense, and it depends upon the sense in which we take it whether we shall admit that the individuality of the thing consists in its thisness or not. I may perhaps make this clear if I ask you to note that there seem to be three senses in which we use the term. We may mean in the first place by the "this" of a thing its bare existence. The thing we call a "this" is undoubtedly taken to exist- "referred to reality." The logical text books would tell us that the term "this" denotes something, although at this early stage of its meaning they might hesitate to say what it connotes. It would be more in consonance with the foregoing analysis to say that mere existence 
for thought (mere denotation if you like) is at this stage the connotation of the term. At a further stage there is less difficulty. "This" means what is here and now. The thing is referred to a place of its own in the worlds of space and time. Besides its denotation, the text books would say, it has the connotation of "being here and now." But, further, it may be taken to represent the thing in its complete individuality as unmistakably "this" and nothing else-completely differentiated from everything else by the peculiar relations in which it stands to them (and at the same time, as we have seen, rendered completely coherent and self-consistent). We may notice further that these three meanings, though separable, are not really separate or discontinuous with one another. They represent three stages in the development of the original concept. From the undifferentiated unity with which it starts, the mind moves onwards to its first most abstract judgment of reality in becoming

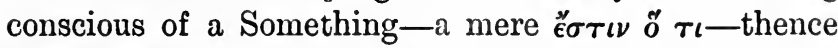
it is carried to its determination under the forms of space and time as a here and now, and from this again to its determinate attributes or essence, its $\tau \dot{o} \tau i$

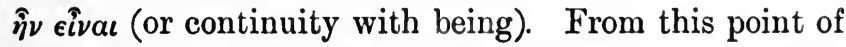
view the objectivity or being-in-the-world of a thing is not something alien to its determination by mindan unresolvable surd-but merely the first of a long series of thought determinations that become through the processes of judgment and inference ever more adequate to express the significance of the point in reality with which we are concerned. Moreover, it is not something which is left behind, but it is a predicate which is taken up as thought advances and absorbed in the concrete reality the thing acquires 
as it becomes more completely known, just as the substance of a seed or embryo is not something that is left behind, but is taken up into the life of the plant or the animal organism.

We only need to apply these considerations to the argument quoted above to perceive that it proceeds upon a quite opposite assumption-the assumption, namely, that the starting-point of knowledge is an unmediated diversity between subject and object. Facing

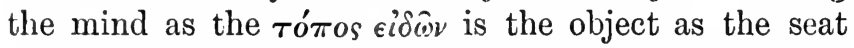
of reality, and knowledge is conceived of as the process whereby a reality having concreteness and individuality in itself is decked with a spurious individuality by means of the abstract concepts which are the predicates of our judgments about it. I do not deny that there is much in the prevailing mode of regarding the problem of the relation of thought to reality which seems to justify such a view. Even the more careful idealist writers are not free from the tendency to lay undue stress upon the logical judgment as the type of all thought, with the result that a division is made at the outset between knowledge and reality, and the mind is conceived of as "in contact with reality" in perception, and having for its problem to bridge the gulf which separates it from the world of existence. But this I believe to be a fundamentally misleading point of view, and it is much more in harmony with the leading lessons of modern philosophy to conceive of the distinction between subject and object, the given and the thought to which it is given, as itself a moment in the development of primitive experience. If this is so, we may admit that the "this," if we take it in the first of the above senses, falls far short of the mind's ideal, but we must at the same 
time deny that it is something alien to thought as such. Similarly we may admit that it is to thought a dead centre, but it is dead not because it is a residuum obtained by abstracting all possible predicates, but because it is itself the first and most abstract of all the predicates by means of which the mind seeks to realise its ideal.

The attempt to mark off a region of thinghood in the object which is unmediated by the subject naturally leads to the attempt to mark off an element of selfhood in the subject which is unmediated by the object, and we need not be surprised that Mr. McTaggart seeks to illustrate his abstract thing by the conception of an abstract ego. Facing the thing as the unity of its attitudes we have the subject as the unity of its perceptions. So far we are on well-known ground. Kant taught as much. But on Kant's view object and subject were both ultimately things in themselves and as such unknowable. This new Kantianism makes a distinction between them. The object as such is withdrawn from immediate presentation: it is only known from without, but the subject as known from within enters apparently immediately into consciousness. One can hardly believe that Mr. McTaggart is really serious with this distinction, or means to assert that there is any knowledge of the self accessible to us which is not a knowledge of the world-any opaqueness in our knowledge of the world which is not reflected in our knowledge of the self. Yet abstractions die hard, and it may be worth while to restate the view upon this head, on which we are all, I take it, agreed, "except when we are supporting a thesis."

We are all, I suppose, agreed as psychologists that 
the attempt to discover in the changing scene of feelings and cognitions a permanent identical content corresponding to the self is waste of time. The consequence of this admission for philosophy is not that there is no self (any more than the consequence of the astronomer's discovery that God was not visible through his telescope was that there was no God), but that it is to be looked for in another way. It is to be sought for at the end, not at the beginning of our mental life, in the extent and organisation of the contents of the mind, not in some needle's point of abstract consciousness. To know ourselves, therefore, is not to have access to some inner shrine of individual life, but to understand the mode in which those contents are united to one another. Our guarantee for the unity of our own life is not any immediate consciousness of it, but simply the fact that organised knowledge exists. We may say, if we like, that the unity of the self is an idea or hypothesis by means of which we render the fact of knowledge intelligible to ourselves. But it would be truer to say that it represents one of the elements which the analysis of developed knowledge yields, the other element being the diversity of the content.

Now if this is so, wherein does our knowledge of the unity of the self differ from our knowledge of the unity of the thing? Here also psychology admits that there is no content over and above the attributes of the thing corresponding to its unity. But this does not mean that there is no unity. It means that the unity is to be looked for in the special form of relation which the attributes bear to one another, that being most of a unity which is most organised and coherent. We may say, if we like, that this unity is a hypothesis 
we make in order to make the "thing" intelligible to ourselves, but again it is simpler to take it as one element or aspect, which the nature of reality forces us to acknowledge in everything we know, the other being the differences or relations in which the unity reveals itself.

A difficulty might indeed be raised in connection with other selves. Is it meant that we have no more immediate knowledge of our own than of other minds? This, it may be admitted, is contrary to prevailing prejudices. For it is commonly assumed that we start from an immediately given self, and arrive later, by a process of analogical inference, at a consciousness of the existence of other minds. Yet one would have thought that recent psychological analysis, laying emphasis as it does on the part which the recognition by others plays in the growth of self-consciousness, ${ }^{1}$ would have led us to suspect this account. It is, of course, true that we interpret other minds and wills by the analogy of our own, but it is equally true that it is in the minds and through the wills of others that we come to know our own. The knowledge of ourselves is in as true a sense mediated as our knowledge of others. We may say, if we like, that we only infer the existence of other minds as the hypothesis that best explains the facts of experience. But no argument can be brought in support of the view that the existence of other minds is hypothetical, which would not apply equally mutatis mutandis to the existence of our own. Here, as in the case of subject and object in general, it is better to say that "others' consciousness" is one of two factors which the analysis of self-consciousness yields to the psychologist, "own-consciousness" being

${ }^{1}$ See, e.g., Sully, Human Mind, vol. ii. p. 100 foll. 
the other. They thus stand on the same level of immediacy, for neither is really immediate at all. ${ }^{1}$

If these contentions are valid, the unity of apperception does not really stand in antithesis to the unity of the percept, as the transparent to the opaque. The two stand on the same level, and must be treated alike. They were so treated by Kant, who placed the ultimate reality of both beyond the sphere of discursive intelligence. The contention of this paper is that this is an überwundene Standpunkt. Its error is, in a word, that it mistakes mere existence for reality. Instead of being the fullest of the predicates of thought containing the reality of the thing as an unrevealed and (let us be frank) unrevealable secret, the determination of it as an existing "this" is the emptiest and most abstract. For it is just that one which cuts it off from other things, and from the mind which thinks it; and just as the surest way to miss the realit, of mind is to look for it in abstraction from the world it knows, so the surest way to miss the reality of the object is to look for it in abstraction from its relations to other things, and to the mind for which these relations exist.

To sum up: We have seen in the first place that knowledge aims on the one hand at exhausting, and on the other at reducing to unity the complex contents of experience. In the second place these two (complete differentiation and complete unification) are not two different ideals, but different sides of the same. They take their place as constituent elements in the process, by which individuality, significance, reality is given to

1 One undoubted advantage of this way of putting the matter is that we cut the ground from underneath the form of solipsism which battens upon the ordinary psychological analysis. 
things. Coming in the third place to the question of the relation of such individuality to ultimate essence, I have tried to show that there is no reason to hold that the system of predicates, which is the form this individuality takes in the mind, is a mere appearance, which, in order that it may correspond to the nature of the thing as it is in itself, must lose this form, and be merged in another, which is no longer knowledge. To maintain this, as has recently been done, is to revive Kant's doctrine of the Thing-in-itself in a form which ignores without meeting the most characteristic contention of modern philosophy, that reality is to be looked for not in the abstract, but in the concrete individual. 


\section{III.}

\section{HYPOTHESIS.}

I. TREATMENT OF HYPOTHESIS BY ENGLISH LOGICIANS.

TEVONS begins his chapter on Hypothesis ${ }^{1}$ with the remark that "All inductive investigation consists in the marriage of hypothesis and experiment." This has not always been the view of English logicians. Bacon's objections to hypothetical anticipations of nature, and to the deductive method in general, are well known. Newton's statement of the law of gravitation was accompanied with a self-denying ordinance in respect to hypothetical causes. Along with the great discoverers of his own and the succeeding age, he would undoubtedly have disclaimed the a priori method of mediæval thought, and would have identified with it a process, the essence of which was to start with an unverified assumption, and go on to deduce consequences from it. And this view was thought, at a later date, to be established on a sound philosophical basis by the speculations of Locke and Hume as to the source of all our knowledge. It is true that, try as he would, Bacon was unable to exclude deduction from his own method, that his great contemporaries and successors, who had already entered on the modern epoch of scientific discovery, consistently employed methods which the prevailing

1 Principles of Science, p. 504. 
philosophy renounced, and that Newton himself propounded hypotheses in the light of which his celebrated disclaimer bears the appearance of irony. But this only shows that the methods these investigators employed were in advance of the means they possessed of analysing them. And it remains true that the attitude of English logicians towards hypothesis during this whole period was one of suspicion and hostility. It is not till we come to our own time that the important place in all scientific investigations of the preliminary assumption, the deduction of the consequences which must flow from it, and the comparison of these with actual fact, was recognised.

The reaction against the purely empirical method is clearly marked in J. S. Mill, who devotes a large section in the middle of his Logic to a description of the deductive method, and to defining the place of hypothesis in science. Jevons gives him credit for the part he took in initiating this reaction, but justly observes that his conclusions in this part of his system are inconsistent with his disparagement of the deductive process in the early part of his work, and his continual appeal to inference from particular to particular as the true type of reasoning. "Mill," he concludes, "would have saved much confusion of thought had he not failed to observe that the inverse use of deduction constitutes induction."

Jevons himself, as we have already seen, cannot be accused of undervaluing the "inverse method." $\mathrm{He}$ is too much of a mathematician to permit his psychological empiricism to invade the sphere of geometry and formal logic. In his view the deductions of these abstract sciences take their place beside the direct intuitions of experience as types of certainty. Similarly, 
he has too keen an insight into the real processes of scientific thought to assign to the deductive method any subordinate place in physical investigation. "There are four different steps," he says, "in inductive reasoning : first, preliminary observation; second, the making of hypothesis; third, deductive reasoning; fourth, verification." 1 On the other hand, Jevons shares with Mill the philosophical assumptions of Locke and Hume, and we cannot be surprised if, in spite of the above contentions, his own theory of hypothesis turns out in its later stages to be infected by them. His difference with Mill is founded on no thorough-going analysis of the nature of truth and the grounds of certainty. Accordingly when, leaving mathematical and quasi-mathematical science, we come to the application of induction to concrete nature, we not only find no attempt to reconcile the acknowledged hypothetical character of scientific method with the appeal of the Empirical Philosophy to simple intuition as the only test of truth, but have the contradiction emphasised in a theory which gives up certainty in physical science as an unrealisable ideal. According to this theory, Perfect or Complete Induction is not to be looked for (as we might expect from the abovequoted views as to the nature of induction in general) in the establishment of hypothesis by deduction and verification, but in that process of complete enumeration which Mill rejected as the mere summation of singular propositions. As compared with the certainty achieved by this latter process, the result of induction in Mill's sense ("proper," as opposed to "perfect," induction) can never amount to more than a balance of probabilities. "Nature," to quote a well-known 
passage, "is to us like an infinite ballot-box, the contents of which are being continually drawn ball after ball, and exhibited to us. Science is but the careful observation of the succession in which balls of various character present themselves; we register the combinations, notice those which seem to be excluded from occurrence, and from the proportional frequency of those which appear we infer the probable character of future drawings." 1 In other words, the truth of even the best-supported hypothesis is problematical. It could only be finally established by the exhaustive consideration and rejection of an infinite number of all possible rivals. Even then there would still remain another ground of uncertainty; for there is always the possibility that the Power which created the universe at the first may introduce a

I change into the order hitherto established in the experience of men. What we call the uniformity

$\checkmark$ of nature is merely an assumption, and like all other assumptions in this field, rests in the last instance on a comparison of conflicting probabilities.

Beginning with a rooted distrust of hypothesis, English logic seems thus to end in establishing it as the only scientific method, but in doing so comes very near denying the possibility of scientific knowledge altogether. Jevons saved himself from this conclusion by appealing to the deductions of geometry and formal logic, and to the intuitions of sense as a ground of certainty. But it is easy to see that he has no right to these exceptions. For it is evident that mathematics and formal logic rest upon assumptions in just the same sense as do the natural sciences. It was Mill's merit to see that this followed from his premises.

1 Principles of Science, p. 150. 
It is no merit in Jevons, but merely indicates confusion of thought to ignore it. No proof can be offered of the axioms of geometry or the formal laws of identity, contradiction, and excluded middle, that cannot be claimed for the uniformity of nature and for well-grounded hypotheses. No doubt can attach to the latter which does not infect the former. If, for instance, it be said that we cannot conceive of a thought which is not governed by these axioms and by the formal laws, this undoubtedly is true, but it is equally impossible to conceive of a world in which uniformity does not exist, or of a knowledge of it which does not rest on hypothetical interpretations. And if, giving up the deductive sciences, Jevons falls back with Mill on the intuitions of sense, it may be shown that these, equally with the generalisations of science, rest upon conceptions of the mind, and are hypothetical in the same sense. The world of sense which, to the early English psychologists, seemed to be an immediate datum is in reality a construction by the aid of conceptions whose only ultimate justification is that they are necessary to give coherence and consistency to our experience. Spatial position, temporal succession, substance and attribute, cause and effect, the identity of the object of intuition with itself, are such conceptions. They are assumptions in Jevons's sense, and if we were to adopt his criterion of truth, would merely at best be the most probable of an infinite number of possible ones.

Having reached this point, which the reader may construe at pleasure as the destruction either of the possibility of certainty, or of the ballot-box theory of the nature of hypothesis, we are in a position to approach the subject for ourselves. 
II. THE NATURE OF HYPOTHESIS.

The first conclusion forced upon us by the above criticism is that as a construction thrown out by the mind to give order and coherence to the data of experience, hypothesis does not differ essentially from other conceptions of the mind categories, axioms, formal or material laws of thought, class notions, universal or ultimate postulates of thought and action. Any conception may be called an hypothesis in the broad sense of the word in which it is used by Plato when he tells us that all scientific knowledge is hypothetical; by which he meant, not that it was indemonstrable, but that it rested on presuppositions, which could only be proved by being shown by philosophy to stand or fall with experience as a whole. The second conclusion is that the proof of a scientific hypothesis in the proper sense may be not less certain than the proof of any other conception, for it is to be sought for like the proof of all others in the extent to which it is successful in introducing consistency and coherence into our experience. The type of certainty here and elsewhere is not the so-called immediate deliverances of intuition. However emphatic and unambiguous these may seem to be, they are neither immediate nor are they ever accepted without a reference to the total experience in which they appear as moments or points of transition. Certainty is always mediate, and the specific characteristic of scientific hypothesis is just that it emphasises this mediacy by bringing it clearly into consciousness.

All this will become clearer as we proceed to examine in more detail the characteristics of hypothesis as a conscious process of scientific investigation. 
While, as we have seen, hypothesis must in any true theory of knowledge be co-ordinated with the more elementary functions of thought, it is necessary for logic to distinguish it from these as well as from certain subsidiary processes which are apt to be confounded with it. Moreover, within the process of hypothesis itself certain elements require to be distinguished from one another if we wish to obtain a clear idea of its essential nature.

In the first place, the conception must be sufficiently separable from the facts to admit of reasonable question before it is recognised by the logician as an hypothesis in the proper sense of the word. This requirement is sufficient to separate it from those conceptions which we have already alluded to as the presuppositions of all experience. The categories are hypothetical in the sense that they are conceptions supplied by the mind in the process of rendering its experience intelligible to itself. They are not hypotheses in the sense that their rights can reasonably be contested, except by one who is prepared to contest the validity of knowledge in general.

In the second place, the attempt to fit a conception to facts must have attained a certain degree of consciousness. This requirement disqualifies another class of conceptions. In the reaction against the mediæval method of deduction from a priori assumptions it was contended, as we have seen, that the true scientific attitude was perfect openness to the impressions of experience. If this is taken to mean that our assumptions, to be of any value, must be founded on observation, the advice, of course, was and always must be in place. But if it means, as it is sometimes with some justice suspected of meaning in the Baconian 
philosophy, that we ought to approach nature with our minds a perfect blank as to what we wish to know or what we may expect to find, nothing could be more misleading. It is only when we approach nature with a question that we can expect to get an answer. Only those who seek find. And seeking, as opposed to rummaging, consists of a series of guesses on the basis of definite knowledge of the conditions to be satisfied by the object of our search. Are all these guesses hypotheses? "Equilateral triangles are equiangular : are equiangular equilateral ?" "Some of the planets and their satellites move from west to east: do all? and if so, why?" "Ranunculi are defined by characters $a, b, c, d$; this flower has $a$ and $b$ : has it $c$ and $d ?$ " These guesses are all, in the first instance, assumptions awaiting verification. Are they hypotheses in the logician's sense? It may be a question of language, and we must not be pedantic. Aristotle would probably

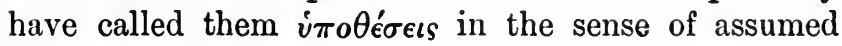
judgments. It may, however, serve for clearness to notice the distinction which Venn makes ${ }^{1}$ between such guesses in the mind of the scientific investigator and the class of assumptions recognised by the logician as hypotheses. Every scientific observer makes use of a multitude of such guesses, by far the greater number of which, if not still-born, survive only a few moments, and are hastily buried. A small proportion, after hovering for a moment in his mind in the form of surmises, without more delay take their place in the system of his experience as demonstrated truth. A few, on the other hand, by virtue partly of the conflict they give rise to between rival factions in his experience-some elements favouring, some opposing

1 Logic of Chance, chap. ix. $\$ 3$ foll. 
their claims-and partly of their importance to science in general, are admitted as a species of catechumen in the world of reality, and recognised as legitimate but unproven hypotheses.

A more difficult question is suggested by another class of conceptions which sometimes pass under the name of hypotheses, but which do not in all respects conform to the requirements laid down by the ordinary definitions. "An hypothesis," says Mill, "is any supposition which we make (either without actual evidence or on evidence avowedly insufficient) in order to endeavour to deduce from it conclusions in accordance with facts which are known to be real; under the idea that if the conclusions to which the hypothesis leads are known truths, the hypothesis itself either must be, or, at least, is likely to be, true." 1 If we accept the last clause as necessary to the definition, we must rule out assumptions of the class known as "representative fictions." Of these fictions several species might be named. There are what might be called fictions of exposition. Clifford proposes it as an explanation of the moon's motion, that she is a falling body, only she is going so fast and is so far off that she falls quite round to the other side of the earth instead of hitting it. This class need not detain us. They are not hypotheses in Mill's sense, for the test of them is conformity not to truth, but to the intellectual range of the reader.

More important and more difficult to deal with are what might be called fictions of simplification. These differ from the last in having a recognised place in the body of science. Their function is precisely

${ }^{1}$ Logic, book iii. chap. xiv. §4. 
analogous to that of legal fictions, and if they are to be called hypotheses at all, they should be called emphatically "working" hypotheses. Their justification is that they work for a particular purpose. A typical example is the assumption of a centre of gravity, the existence of which not only cannot be demonstrated, but can be shown to be impossible. A similar fiction is implied in differential equations of the kind quoted by Lotze ${ }^{1}$ where, as in the endeavour to reach the conception of a circle by means of that of the polygon inscribed in it, it can be shown that the sign of equality is untrue until we reach the limit where the sides of the polygon are infinitely small, and when we reach the limit the quantity in one side of the equation has become 0 and there is no longer anything to equate. Seeing that a working fiction of this kind need not be true in the sense above defined, a conception which was once accepted by science, but has become superannuated, will sometimes serve the purpose. Thus, as Jevons remarks, the Ptolemaic theory of cycles and epicycles, though long since pensioned off as a tenable hypothesis, may still be employed as a legitimate mode of subjecting the motions of the heavenly bodies to mathematical analysis.

A third class of representative fiction deserves to be mentioned at the risk of tediousness on account of its importance in the history of science and of controversy. I mean those abstractions which are not merely legitimate in science, but seem to be necessary if there is to be science at all. The most conspicuous instance under this head is the assumption by mathematics of the existence of its subject-matters, space

1 Logic, p. 351, English Translation. 
and number, distinct from the objects whose relations they express in the concrete world of experience. To the same class, perhaps, belong the "atoms" of the physicist, the "sensations" of the psychologist. This is not the place to discuss the nature and justification of these assumptions. It is sufficient to have indicated their character as working conceptions, and in doing so to have suggested a not unneeded warning against treating them as hypotheses for which a place has either to be denied or vindicated on the ordinary terms.

Finally, allied to the first class above mentioned and requiring merely to be named to be distinguished from hypothesis in the proper sense, are illustrative supposals in which we are asked to "assume for the moment." Here there is, as a rule, no pretence that the conditions assumed are actual. The characteristic feature of this class is that an arbitra abstraction is made from the conditions of experieme resembling the arbitrary isolation of experiment with a view of bringing into prominence the consequences that flow from it.

\section{THE CONTENTS OF HYPOTHESIS.}

From this attempt to separate hypothesis proper from kindred conceptions, we may pass to consider the contents of the former. The difficulty here is that it is of the essence of an hypothesis so long as it remains such to be in a constant state of change. What appears at first as the bare suggestion of something which is necessary in order to explain the facts gradually clothes itself in the special form that reflection, as it advances, shows to be required in anything that is offered as a sufficient explanation. This 
difficulty will best be met by distinguishing between what, borrowing from Lotze, we may call the postulate and the actual content of the hypothesis itself: the form of the problem or the precise definition of the data and the form of the answer. The proof of an hypothesis consists, as we shall see, in the coalescence of these two elements in a new conception of the data as a system of interrelated parts, but it is characteristic of the earlier stages of an hypothesis that they fall apart: there is on the one side a rough outline of the facts to be explained, on the other a rude surmise as to the ground of explanation. It is true that no guess or hypothesis can be of any value which is not founded upon observation, but the observed facts are at first only vaguely apprehended, and are only gradually defined as one after another of the elements of the problem are brought into clear consciousness by the criticism to which the hypothesis itself is exposed as reflection advances.

I shall have occasion hereafter to illustrate more in length this process, which might be called the development of the postulate; meantime, it may be sufficient to refer to a well-known example. In the Introduction to the Origin of Species, Darwin tells us that at the outset of his investigations he devoted five years to accumulating and reflecting on all sorts of facts which could possibly have any bearing on his problem before allowing himself to speculate on the subject or note down the general results. He goes on to give a general indication of the steps by which the problem gradually took shape in his mind. In the first place he saw that it was not enough to prove that species were descended from other species instead of being, as popularly supposed, independent creations. "Such a conclusion," he 
says, "even if well-founded, would be unsatisfactory until it could be shown how innumerable species inhabiting this world have been modified so as to acquire that perfection of structure and co-adaptation which justly excite our admiration." Secondly, he soon arrived at a quite definite conception of the inadequacy of the common attempt to explain these variations by referring them to external conditions, such as food, or climate, or even the internal modifications of habit. Such an hypothesis, he tells us, could not satisfy the conditions imposed by the delicate adaptations of the structure of the woodpecker or the mistletoe to its functions. Finally, he had the insight to see that the variations caused by artificial selection offered the best analogy to the natural varieties of species. "At the commencement of my observations it seemed to me probable," he says, "that a careful study of domesticated animals and of cultivated plants would offer the best chance of making out this obscure problem." Even before he permitted himself, according to his own account, to anticipate the answer, the problem had thus apparently acquired the quite definite form: Is there any procedure analogous to that of the breeder and the horticulturist by which nature can be conceived to select and perpetuate desirable variations? So closely does he here appear to have defined the postulate that to us, who look back upon his statements from the vantage ground of familiarity with his later conclusions, the answer seems ready to start out of the statement of the problem.

In considering the contents of hypothesis in general, we may start from the distinction which Mill draws between the suggestion of an agency and the suggestion of a law or mode of operation. He seems to 
consider this to be an exliaustive account of the forms which scientific hypotheses assume. As an instance of the first, he quotes the rival hypotheses respecting the nature of light, the one ascribing the phenomena to a fluid emitted from all luminous bodies, the other to the undulations of a material substance pervading all space. As an instance of the latter, he gives the different assumptions that were made as to the law of the planetary central force anterior to the establishment of Newton's law that the force varies as the inverse square of the distance.

In reference to this account it ought, in the first place, to be remarked that the distinction between an agent and a mode of operation is a vanishing one. Mill, indeed, has no sooner made it than he proceeds to whittle it away. An agent ought to be something substantial, yet Mill seems to contend in a subsequent passage ${ }^{1}$ that the ether and the undulations with which it is supposed to vibrate, which he gives as an instance of such an agent, ought not to be taken as substantial existences, but are merely a figure of speech descriptive of the way in which light operates. And this view of the instance in question seems to be favoured by Jevons when he warns us against hastily identifying the ether which is supposed to undulate in light with the ether which is supposed to possess the attributes of a material substance and offer resistance to comets. It is, indeed, important to note that the chief problems in physical science as now interpreted concern quantitative determinations of material forces and substances, and that the mathematician may proceed in the discovery of the correct

${ }^{1}$ See Logic, vol. ii. p. 25 fin. 9th ed., and the note on Whewell, p. 24. 
formula by a method analogous to that of the physical observer; but to say this is one thing, and to say that hypotheses are rightly classified in the way proposed, or may ever legitimately be said to have an agent for their content, is another. It seems better, on the whole, to take hypotheses, so far as they are concerned with causes at all, to refer to modes of operation than to substantial existences. Even in Mill's second instance of the corpuscular theory of light it might be pointed out that to say that light is fluid is merely to say that bodies operate in the way we call light by penetration and not merely by propagation of motion. If in reply it be said that we frequently do imagine to ourselves actually existing things as opposed to laws of action, we open up a question to which we shall have to return at a later point (pp. 249 and 250). Meantime, it may be asked what precisely is meant by this contention. If by "things" we mean substances whose attributes are exhausted in the special relations required for the explanation of the facts we are considering, such existences are a contradiction in terms, inasmuch as the definition of a thing or a substance implies that it is of such a nature that it cannot be thus exhausted. If, on the other hand, we say that we mean concrete things with attributes or modes of operation other than those which are needed to explain the phenomena under observation, the hypothesis, as we shall see, is of doubtful legitimacy unless we can point definitely to the lacuna in reality for which these supernumerary attributes are required. But, setting this doubt aside, and assuming that it is permissible to imagine concrete things otherwise unknown to exist, for the sake of those of their attributes which are necessary to explain the 
phenomena in hand, we have not in our hypothesis got beyond their attributes or modes of operation; for it is they and not the concrete thing that are required by the theory we have constructed and form the real content of our hypothesis.

Mill's treatment of this subject is misleading in a second respect. We have already seen that Mill shares to a large extent the suspicion with which early inductive logicians regarded hypothesis. This suspicion, together with the view just alluded to, that hypothesis is exclusively occupied with substances and the laws of their operation, lead him unduly to limit the range of its application. With a view, as he says, "to guard against the appearance of reflecting upon the scientific value of several branches of physical inquiry which, though only in their infancy, I hold to be strictly inductive," he makes a distinction between inventing agencies to account for classes of phenomena, and endeavouring, in conformity with known laws, to conjecture what former combinations of known agents may have given birth to individual facts still in existence. In conformity with this distinction he proposes to exclude geological inquiries into the origins of rocks, and Laplace's speculations as to the origin of the planetary system from the scope of hypothesis.

From what has already been said as to the essential identity of the procedure which Mill distinguishes as "strictly inductive," and the deductive method in which hypothesis has a place, it is obvious that there can be no real distinction between the theories in question and those which he has previously admitted as cases of genuine hypotheses. It is, of course, true that all of them have now advanced beyond the stage at which they can with justice be considered as mere hypotheses, 
but this cannot be taken to mean that there was not a time when they all existed in the form of suggestion, and were even consciously recognised as such. And this, we saw, is the characteristic mark of an hypothesis in the strictest sense of the word.

The important question is not whether these theories are formally different from such as are admittedly hypothetical, but how and at what point they passed from the stage of interesting suggestions to that of established theories.

One other misapprehension deserves mention only because of the persistency with which logical text books, following Mill and Jevons, have suggested it by the illustrations which they employ. These illustrations are chiefly drawn from the physical or at least the natural sciences. They thus suggest the undue limitation of the inductive method, and are doubtless partly responsible for the prevailing impression that the methods of investigation and the certainty of the results available in art and philosophy are fundamentally different from those of the experimental sciences. Even in the latter they obscure the extent to which the naturalist is engaged in the search for other forms of identity in difference besides that of causal connection. For these reasons it may be worth while remarking that all that is here said on the nature of hypothesis is equally applicable whether the context be the meaning of a passage in literature or a work of art, the motive of an action, the character of a human agent, the purpose of an organ or mechanism, the identity of a thing or person, continuity of evolution through a series of forms, or that particular form of continuity which we call physical causation. 
Some further questions of a preliminary kind are raised by the so-called "rules" which were formulated by older writers to restrain the "licence of imagination" in the invention of hypotheses.

\section{ROLES DEFINING LEGITIMATE HYPOTHESIS.}

The rules that have been laid down are: 1 . The hypothesis must be required. 2. It must not contradict the laws of nature. 3. It must be adequate. 4. It must be a vera causa.

These rules, it must be admitted, are apt to turn out on closer examination to be either trivial or mistaken. To the former class clearly belongs the warning against "gratuitous assumptions" contained in the first rule. In illustration of the second, Fowler quotes the theory that fossils were strewn on the tops of mountains by the devil in order to cast suspicion on the biblical account of the creation. In cases of this kind we might dispense with a formal rule. In other cases the difficulty is to distinguish what are laws of nature. Thus, in opposing an hypothesis on this ground, we have to make sure, as Jevons warns us, that the laws to which we appeal are themselves valid inductions and not assumptions on the level of the mediæval maxim that Nature abhors a vacuumwhich she does not appear to do if the vacuum is over thirty-two feet high, or that force can only act through a medium - which would have excluded Newton's theory of gravity as a legitimate assumption. But on this point the rule gives us no assistance. The third rule lays down the requirement that the cause assigned for an event must be adequate to produce it. This either means that the cause 
assigned must not be in flagrant contradiction to the facts to be explained as postulated at the outset, in which case the rule is implied in the definition of hypothesis, or if we define an adequate cause as one which is necessarily implied in the effect, and therefore the only possible one, the rule can only be admitted as the test to which the hypothesis must submit before it can claim to be demonstrated truth, and can have no meaning as a preliminary test to bar the way against fanciful suggestions.

There is a similar difficulty in assigning a precise meaning to the fourth rule, that the cause assigned must not only be such as, if admitted, would explain the phenomenon, but must be a vera causa. Newton's authority has won for this maxim general acceptance among logicians. But when we come to inquire what meaning has to be assigned to it we find that quot homines tot sententice. By some it is interpreted to mean that no cause ought to be assumed which is not already known to exist. If such a rule were accepted we might ask how any new cause could come to be discovered. Mill holds it to be unnecessary that the cause should be previously known to exist, but requires, in terms of what he conceives must be the true meaning of the maxim, that the cause assumed must be such that its existence may afterwards be detected by independent evidence. If by independent evidence is meant direct perception, it can never be admitted that inaccessibility to sense-perception is a sufficient ground for rejecting what the conditions of experience force us to assume. Otherwise, as Dr. Bosanquet points out, we should have to reject the centre of the earth and the other side of the moon as legitimate conceptions. If, on the other hand, we 
mean by independent evidence a train of reasoning founded on facts other than those under investigation, we have a statement both comprehensible and useful. It was the absence of such evidence (to take a wellknown instance) that led Darwin, in his investigation on the distribution of seeds, to reject the hypothesis of continental transmission. "It shocks my philosophy," he wrote to Hooker," "to create land without some other and independent evidence. To imagine such enormous geological changes within the period of the existence of now living beings on no other ground but to account for their distribution seems to me, in our present state of ignorance upon the means of transportal, an almost retrograde step in science," its retrogradeness consisting, as he elsewhere informs us, in its tendency to check "a close study of the means of dissemination."

It may however be doubted whether such independent evidence is a necessary condition of legitimate hypothesis. The conception of a luminiferous ether is, I presume, universally admitted as a legitimate hypothesis, and will continue to be so even on the assumption that it is non-resistant, and that it cannot therefore be independently proved to exist from the side of astronomy by appeal to its retarding effect upon the motion of heavenly bodies. For this reason it has seemed to some that a new meaning has to be assigned to the vera causa, which it has been proposed to define as " a thing or occurrence in a thing whose reality we are thoroughly convinced of from the necessity of reconciling observed data." ${ }^{2}$ But in giving this definition it ought to be noticed that

1 Letters, vol. ii. p. 59.

2 Bosanquet, Logic, vol. ii. p. 159. 
we have again passed from the test which should be applied to an hypothesis before it be admitted as worthy of serious consideration at all to the test which it must satisfy before we can finally accept it as a demonstrated theory.

From the difficulty which we thus see is experienced in endeavouring to lay down the a priori conditions of legitimate assumption we may be led to suspect that the whole attempt is a mistake, and has its origin in the early misunderstanding as to the essential nature of hypothesis already sufficiently noticed.

Leaving, therefore, the attempt to find meaning in the meaningless, we may now pass to the question of the nature of the process by which an hypothesis passes from the probationary to the probate stage of its existence.

\section{THE AIM OF HYPOTHESIS.}

The question is, By what test are we to decide the claims of an hypothesis to rank as demonstrated theory? As this test can be nothing other than the extent to which it fulfils its aim or function, a short statement of the nature of that aim will be the best introduction to the answer. Everyone will agree that the aim of hypothesis is explanation, but this does not help us until we understand what mode of apprehending a phenomenon constitutes an explanation of it. The common answer would be the apprehension of it as the effect of a given cause or an instance of a given law. The answer is correct provided that we understand by cause or law not merely another phenomenon or event which merely precedes it. So long as the cause or operative principle is conceived of as standing outside its effect as a mere event in 
time, however close, invariable, or unconditioned the connexion may be conceived of as being, it cannot be said to explain it. Not until "cause" and "effect" disappear as mere events, or if retained are seen to be a mere arbitrary division in a continuous process, or the arbitrarily chosen names for different elements in a systematic whole, can we be said to have an explanation in any true sense.

Thus, if the question is, What is the explanation of water? the answer is, The union of two parts hydrogen to one of oxygen. This is true, but not in the sense that the formation of water as one event has been referred as a consequence to an antecedent event, the union of oxygen and hydrogen. These are not two distinct events. If they were there would be no explanation. The oxygen and the hydrogen pass into the water, and the water is $\mathrm{H}_{2} \mathrm{O}$, the effect is the cause. It is not the separation of the whole phenomenon into two events that gives us the explanation, but the apprehension of the substantial unity of the elements under the difference of form.

Or, to take a more complicated example more akin to our subject: a shot is fired, a man drops dead. To the passer-by the one event seems to be explained by the other. But let it be suggested that the man who has just dropped is subject to apoplectic fits. Clearly the explanation is inadequate. It will remain so even though marks of a wound near the heart are visible. Apoplexy may still have been the cause, brought on by fright. The explanation of the death as the direct result of the shot is only complete when the path of the bullet is seen to be incompatible with the continued action of the heart, and when the phenomenon, instead of being marked off into two or more discontinuous 
events as at first, has resolved itself into a continuous development, and is recognised as a series of changes in a material medium whose elements act and react on one another according to predetermined laws. By the time that this has happened two things have become obvious from the point of view of the logician: $(a)$ the circumstance alleged in explanation has been proved able to account for the facts-the cause to be adequate to the effect; (b) it alone can account for them-the particular effect demands the particular cause.

The process by which, in the case of any hypothesis, certainty is obtained on these two heads is the establishment of the hypothesis; and we have now to consider wherein precisely this process consists.

\section{THE VERIFICATION OF HYPOTHESIS.}

Our previous discussion of the way in which the postulate is developed has already brought before us one side of this process. The hypothesis undergoes a series of corrections and extensions by which it is brought into closer and closer connexion with the facts that are to be explained. In respect to the corrections which are thus made upon the original suggestion, there is no essential distinction between what would generally be acknowledged to be a mere correction of the same hypothesis or the substitution of a better one for it. Rival hypotheses, if they are legitimate at all, must imply many common assumptions, and it is a matter of degree whether we ought to treat them as varieties of the same or as different hypotheses. The corpuscular theory of light had in common with the undulatory the important point of assuming that light was motion. The question between 
them was what it was that moved, and it is logically indifferent whether we regard the crucial experiment which proved that it was the medium and not an emission that moved as having effected an amendment upon the motory theory of light, or as having established the undulatory as against the corpuscular. The advantage of the former of these two ways of regarding the matter is that it enables us to treat the history of a theory as a continuous development rather than as an irregular skirmish with accidental opponents. The steps in this development are represented by the failure of the accepted hypothesis to explain facts which, when we take it in an amended form, offer no difficulty. Such facts are the instantia crucis of the logicians. On the above view they are not so much finger-posts at a cross-road as stagehouses on the highway of explanation. They mark the places where a change has had to be made : an old assumption abandoned, and a new one substituted in its place.

Illustrations of such instantice are the successive stages through which the theory of the fertilisation of plants developed. So early as 1682 Grew announced his belief that for the purpose of fertilisation the pollen must reach the stigma, which he took to be directly effected by means of the proximity and position of the pollen masses. This hypothesis was confronted a century later by Sprengel with the case of flowers like the orchid and the blue flag, in which, owing to the position of the stigma and the pollen, contact was impossible. These cases suggested to Sprengel that union was effected by insects. Darwin gives him the utmost credit for this discovery, and for the way in which he worked it out. Sprengel seems, 
however, to have confined his attention to the single flower, and to have overlooked the problem as to how fertilisation was accomplished in cases like that of the sage and the English arum, in which the pollen and the pistil reach maturity at different times. This crux marked a point at which Sprengel's theory of insect fertilisation passed into Darwin's farreaching speculation as to the cross-fertilisation of plants.

This is the one side of the process under discussion. The hypothesis is secured in the rear. It is put forward as explaining what earlier hypotheses cannot explain. There may be much yet which it has not explained, but there is nothing which can be shown to be inexplicable by it. But this is not enough. We have to show, not only that the assumed cause is able to produce the given effects, but that no other cause can. Not only given $a$ then $b$, but given $b$ then $a$. It is here, as we have seen, that Jevons found induction defective. It fails, he held, and necessarily fails to give us the required assurance. It is still open to anyone to maintain that our result is only probable. In the vast reservoir of nature there may be an unknown multitude of causes which are all adequate to explain the given effect. As this is to misconceive the nature of scientific explanation, and to substitute for the positive movement of thought by which the cause passes over into the effect, and is seen to be one with it, the merely negative process of securing it against rivals from without, it is important to notice the precise nature of the movement of thought which completes the proof of an hypothesis.

It consists in the counterpart of the process I have just described as the development of the hypothesis, 
and may be called the individualisation of the facts. Not only does the hypothesis undergo modification as it is gradually "moulded" to the facts, but the facts themselves undergo a similar process of transformation. New facts emerge as deductions from the hypothesis, and a new form is given to others that have long been familiar. The former of these effects is noted by most of the logical writers who treat of the subject as one of the chief means of verifying an hypothesis. By enabling us to forecast properties or events, the hypothesis affords striking evidence of its truth. The predicted discovery of the planet Neptune is a frequently quoted example of the deductive method. But the power of prediction is only a function of the power of individualisation of which I am speaking. It is founded on the correlation of facts hitherto apprehended in isolation, and it is this correlation, and not the power of prediction founded upon it, that is the source in the mind of the discoverer of the assurance that he is in possession of a vera causa. That it is a sufficient source I may try to make evident by an illustration.

I have elsewhere referred to a child's picture-puzzle as analogous to the problems of nature. The task is to project a scheme which will reduce a confused mass of detail into an orderly system. Should the pieces be cubes differing from one another merely in the colour of their surfaces, it is true that many patterns may be possible. A case of this kind would correspond to Jevons's instances from the ballot-box. But where the parts possess an individuality of their own, either by reason of the shape or the figures on their surfaces, there is usually only one way in which they can be combined. The more concrete nature of the material secures us 
in this case against an unknown multitude of rival schemes. This is so also in nature. The objects and events with which we are dealing exhibit characteristics that presuppose definite relations to others. The only proof, and the sufficient proof in the one case as in the other that the clue has been found, is that by means of it the elements arrange themselves in a coherent system, and in so doing undergo a process of individualisation which is also a transmutation. In one important respect the illustration fails, as all illustrations from artificial problems must fail, to represent the nature of scientific verification. In the system of nature the principle, if it is a true one, not only introduces law and order into a field where previously we had only a number of isolated observations, but brings the whole field into relation with other known laws, imparting to it as a whole a new significance as an illustration of a more general principle. The individualisation I have spoken of affects not only the elements within the given system, but the system itself as a portion of a larger one. When it has been effected by the coalescence of the elements of hypothesis and fact, the verification is complete. There is no longer any sense in the suggestion that a different hypothesis is still possible. This is in reality equivalent to suggesting that the facts themselves may be other than they are. They may, of course, in the sense that anything may be anything else. But if no ground can be shown why we should hesitate to accept them as they are, the objection is "motiveless," and, if pressed, could be shown equally to apply to the data of sense and the deductions of formal logic and mathematics. 


\section{ILLUSTRATION FROM DARWIN'S SPECULATIONS ON CORAL ISLANDS.}

The nature of this process as it actually takes place will best be seen in connection with a concrete example. I select one which has always seemed to me from a logical point of view peculiarly complete. ${ }^{1}$ It is, of course, simplified and condensed.

In a passage of the Naturalist's Voyage, and afterwards in a separate volume, Darwin has expounded his theory of the origin of the coral formations in the Pacific Ocean. To the early discoverers these appeared to fall under three heads. First, there were those that lay close into the shore, forming simply fringes of coral round about it. Next there were barrier reefs lying further out, and with deep lagoons between them and the shore. Finally, there were the atolls or lagoon islands. These last were the most striking and were early made a subject of speculation. The typical atoll is a lagoon surrounded by a ring of coral reef. Outside, the barrier is exposed to the breakers of the ocean; within, all is quiet, and the first hypothesis was that these islands had been built up by the coral animals to afford themselves protection on the inner side. This did not meet the postulate, for so far from needing protection, the outside corals are found to grow more vigorously than the delicate branching kind that is found within. For this theory was next substituted the widely accepted view that they were built on the craters of submarine volcanoes. The attempt to account for the facts on this hypothesis brought into prominence further elements in the postulate. The size of some of them, which extend to over fifty

${ }^{1}$ I am aware, of course, that the theory itself has been disputedrecently by Professor Alexander Agassiz. 
miles in length by twenty in breadth, and the form of others, which consist of a number of little separate atolls, were seen to be incompatible with this assumption. A third theory was founded on the true observation that the corals which are most exposed grow most vigorously. Hence from an area of coral at the bottom of the sea the outer edge would spring up most rapidly and hinder, by their protection, the growth of others inside. This theory, however, was defective in two respects. In the first place the coral is known not to be able to live and work at a greater depth than from twenty to thirty fathoms. How, then, are we to explain the formation in the depths of the sea of the foundations of rock and sand on which these atolls are erected? Secondly, no theory can be satisfactory which does not include in its explanation the whole three classes of related structure-the lagoon, the barrier, and the fringing reef.

The postulate for a satisfactory theory having been laid down, Darwin begins with the question overlooked by the last theory, that of the foundations. Three views are here possible-the infinite number of possible alternatives is a fiction of the mathematicians. Either these highlands in mid-ocean must be sediment, or they must have been uplifted, or they must have sunk down. The first is excluded. Deposits in the central and deepest parts of the Pacific are inconceivable. The second is also excluded by the fact that we have many vast areas thickly studded with atolls, all reaching to between twenty and thirty fathoms down. Whence these symmetrical submarine mountains? They are without parallel in nature. The third alternative is left. The land must have sunk into the sea. This is the hypothesis with which Darwin starts. 
It at once gives a clue to the leading features of the system. Beginning with the fringing reefs, we see here no trace of subsidence. These lands are stationary or recently uplifted. The reefs are close in to lands where they first were built at the necessary elevation. Next we have the barrier reefs. Here the land has been sinking, and as it sank the lagoon has widened, the reef still remaining above water, as the coral builders have been able to keep pace with the gradual subsidence. Finally, the land has disappeared below the surface and only the reef remains, giving us the third species, or the atoll.

All this corresponds to what Mill calls deducing the consequences. Taken by itself it may appear somewhat speculative. Does appeal to the facts offer direct evidence of the subsidence assumed? Yes, old cocoanut trees on the edge of the lagoon on one island are seen to be undermined and making ready to plunge in; the natives report that the foundation part of a shed now below the tide-mark stood formerly above it; here also earthquakes have been recently felt.

But it is not only the large features that are thus systematised. If the account given is true, many of the subsidiary features of these islands will now become intelligible. It is known, for instance, that the fresh water of streams injures the corals. Hence, in the fringe reefs there will be gaps where the streams enter the sea, and, if our explanation be true, the openings when thrown further out to sea by the subsidence of the land will face the head of the valleys formerly drained by the stream. This is found to be the case. Owing to subsidence at unequal rate of parts of the solid rock that underlie the reefs, we 
may expect to find portions carried down below the depth at which the corals can live and build, and accordingly the reefs broken and irregular; and for the same reason we may expect to find reefs below the surface either "half-drowned" or altogether dead. All these phenomena are of frequent occurrence. Finally, there ought, according to the hypothesis, to be a certain order in the distribution of these different groups, the first of which (the fringe reefs) are upon land that is comparatively stationary or that has been recently elevated; the other two upon regions which are sinking. That this is actually the case is shown by Darwin on a coloured map on which the atolls and the barriers are tinted dark and light blue respectively, the fringes red. The blue are then seen to mass themselves together in different parts of the map, the red in other parts.

It is here that the hypothesis breaks away, as above described, from the limits of the system which it was formed to explain, and gives further proof of its validity by uniting itself with the general theory of the process by which our continents and oceans have been formed. For while we know from other evidence that the great continents are, for the most part, rising areas, the evidence of the coral islands goes to prove that the central parts of the great oceans are subsiding.

"We see in each barrier-reef a proof that the land has there subsided, and in each atoll a monument over an island now lost. We may thus, like unto a geologist who had lived his ten thousand years and kept a record of the passing changes, gain some insight into the great system by which the surface of this globe has been broken up and land and water interchanged." 1

1 A Naturalist's Voyage, chap. xx. fin. 
VIII. MARGIN OF INDETERMINATENESS IN ESTABLISHED HYPOTHESIS.

What we have said must not be understood to imply that an established hypothesis leaves no room for questions which may affect it in detail, and even lead to important modifications of it. There may still be a wide margin of indeterminateness in two respects.

In the first place, while no fact can be pointed to within the special field of the hypothesis which can be proved to be inexplicable, a theory may yet leave many which are not yet explained. In connection with his great discovery of the law of natural selection, Darwin over and over again alludes to this distinction between facts which would invalidate his hypothesis by being in contradiction with it and facts which as yet have not been seen to be in harmony with it or to be capable of being explained by it. "If," he says, "it could be demonstrated that any complex organ existed which could not possibly have been formed by numerous successive slight modifications, my theory would absolutely break down."1 And again, "If it could be proved that any part of the structure of any species had been formed for the exclusive good of another species, it would annihilate my theory." 2 On the other hand, he enumerates a number of facts, - such as the instincts of animals like the bee and the ant, the electric organs of fish, and the neuter gender of certain insects, - which still offer difficulty, and may require more knowledge than we at present possess for their full explanation.

The second respect in which doubt may attach to an

1 Origin of Species, 6th ed., p. 146.

2 1bid., p. 162. 
hypothesis without affecting its essential truth is the extent of its application. The general tendency of the human mind is to exaggerate the extent to which a newly discovered principle is applicable to reality. Subsequent progress consists in a more careful adjustment of the limits within which it holds true. The history of science and philosophy offers numberless illustrations. The rise of mathematical science, and the triumphs of its principles in the fields of number and space, led the Pythagoreans to apply them to explain the nature of reality in general. At a later date the physical method produced the atomic philosophy. In our own time the discovery of the close connexion between physiological and psychological processes has been made the ground of a theory which reduces thought to a secretion of the brain. Subsequent reflection has in each case sought to limit the application of these principles, but the limitations introduced have left the validity of the principles within their own field untouched.

So with conceptions which are recognised as more strictly hypothetical in their origin. The Darwinian theory again offers an illustration. There are two main respects in which attempts have been made to limit its application. From the side of science grave question has arisen as to how far the principle of inheritance can be carried. Does it extend to traits of character which primarily owe their origin to habit, as Darwin seems to have supposed? Or must we limit it, with Weismann, to organic variations? Whatever the conclusion of this controversy may be, the validity of the Darwinian hypothesis as a whole is unaffected. Inherited variation is still a vera causa of divergence of species, though its action may be shown to be 
crossed and complicated to a greater extent, or, again, to be simpler and more direct in its operation than was at first supposed. Secondly, from the side of philosophy, the claim put forward by professed Darwinians to have offered a satisfactory explanation of the intellectual and moral life has been questioned, and rightly questioned, by more recent thinkers, on grounds that do not concern us here. This limitation, however, again refers only to attempts to apply it beyond its. legitimate sphere. While limiting in one respect, philosophy may be said to have confirmed it in another by showing that it possesses the best guarantee of truth in having made the origin of natural species only another illustration of the principle of evolution previously recognised in the history of human civilisation and the human mind (e.g. by Hegel, Comte, and Spencer), and thus brought the theory of it into line with conclusions already established in other fields. 
IV.

\section{IS THE KNOWLEDGE OF SPACE A PRIORI?}

THHE subject was suggested to me by the casual re1 mark of a friend who was himself a Neo-Kantian, and an intelligent person to boot, to the effect that, in view of the advances in recent psychology, the Kantian doctrine of Space was no longer tenable. It came as a surprise to me, as it had never occurred to me that they had anything to do with that doctrine as now understood. But as it seemed to be possible for one even of the initiated to hold this view, I thought it might be worth while to try to re-state the Kantian doctrine in connexion with the most recent results of psychology.

What is meant by Knowledge of Space? There are three senses in which we may understand the phrase :-

1. The presentation of extensity, which, so soon as it becomes an element in anything that can be called "experience," is the presentation of a world whose parts are outside one another.

2. Knowledge of the definite Space relations: position, magnitude, form, distance within that world.

3. Knowledge of Space "as a whole"-the abstract idea of Space as a form of unity in our experience.

As these upon any view must be regarded as stages in the development of complete spatial knowledge, the 
controversy on hand must clearly concern itself in the first instance with the first.

What is meant by a priori? The doctrine that the knowledge of Space is a priori may be stated in two forms: (1) There is the older form, of which Schopenhauer's statement as quoted by Professor James ${ }^{1}$ may be taken as a type. According to this, space is an "innate a priori, anti-experiential form," which somehow "lies already performed in the intellect or brains," and within which we construct the physical universe. (2) It hardly needs to be explained that this is not the sense in which the Kantian doctrine is now held. There is no question of a fully developed preexperiential form into which the mind fits an empirically given non-spatial matter. What is contended is that in our earliest experience of spatiality there is an element which is not given in the mere sensation (if we can speak of such a mere sensation at all), but is given with it. It is a matter of nomenclature whether we call this a "form," or an elementary act of judgment. The point is that it is there as the rudiment of our later spatial judgments. Before going on to oppose this doctrine to the most recent statement of the Sensationalist position, I shall notice shortly the older attempt to assign an a posteriori origin to our knowledge of Space.

The older doctrine started from the assumption that spatiality is not immediately given in sense-experience. It must therefore be shown to be "evolved," or "chemically compounded," out of the immediate data of sense. The most distinguished representative of this view is, of course, Mr. Herbert Spencer. His view may be found in his Principles of Psychology,

${ }^{1}$ Principles of Psychology, vol. ii. p. 273. 
chapters xiii., xiv., xxii., and (re-stated in reply to criticism) in Mind, of July, 1890.

The data from which the knowledge of co-existing positions, which is the kernel of our knowledge of spatial relations and of Space in general, is evolved, are these: (1) Disparate, tactual, or visual sensations, as at the two corners of a book upon the table. (2) A series of reversible muscular sensations as the organ moves from one to the other. (3) The simultaneous (or what amounts to the simultaneous) presentation of the disparate sensations, as when our hands touch both corners of the book at once. The process by which out of these data the knowledge of co-existence is generated is the process by which the simultaneous presentation, being a "quasi-single state of consciousness," comes in time to be taken as the equivalent of the series of states, and to be habitually thought of in place of that which it symbolises.

Now if this is all that Sensationalism has to offer by way of explaining the origin of our knowledge of Space, it is not surprising that J. S. Mill, the candid friend of British Empiricism, should feel himself constrained to admit that "the idea of space is at bottom one of time." Mr. Spencer is not so easily daunted. $\mathrm{He}$ has scientific analogies at command to show how by a gradual transition we may pass from one form of reality to another which is qualitatively different from it. It is no more difficult to conceive of the idea of space emerging from the idea of a time series than to conceive of a circle becoming a straight line by gradually prolonging one of the axes, the molar motion of the stroke of a hammer passing as molecular motion into heat, or the same uniform dermal tissue transforming itself in the process of evolution into hair and nerve, tooth and eye. 
We need hardly stop to discuss the relevance of these analogies. In order to prove by this method that the idea of Space can be built up out of successive muscular and tactual or visual sensations, Mr. Spencer would have to show that a circle can be built out of squares, gravitation out of simple motion, or the Lord Mayor's coach out of a pumpkin. The whole speculation of the empirical school in this country, if the truth must be told, has been unfortunate upon this subject. Excluded from the easy solution of an a priori presentation, and failing to find spatiality among the simple data of sense-experience, the consistent Sensationalist had only one course left to attempt to construct it out of the isolated successive sensations of touch, vision, and the muscular system. The whole proceeding reminds one of nothing so much as the brothers in The Tale of a Tub, who set about evolving permission to wear the much-coveted shoulder knots from their father's will. Although it could not be obtained totidem verbis, nor yet after the most ingenious attempts totidem syllabis, there was nothing to prevent the words being evolved in a third way: totidem litteris. True, $\mathrm{K}$ was not be found. But this was only what was to be expected in so ancient a document, and ought not to be allowed to stand in the way. Only by a similar tour de force can successive presentations be made to spell the spatiality of which we are in search. What lends colour to the deduction of co-existence of positions from simultaneous or quasisimultaneous sensations of touch and vision is that without warning the latter are interpreted as though they already were sensations of position. "The primitive element," Mr. Spencer tells us, "out of which our ideas of visible extension are evolved is 
a cognition of the relative positions of two states of consciousness (sic) in some series of such states consequent upon a subjective motion." But seeing that "position" implies Space, what is this but to assume, as already given, what you profess to exhibit as a result?

The results of recent psychological analysis have given new hope to Sensationalists and a new turn to the discussion. These results may be epitomised under the following heads: (1) Besides the particular quale of the presentation itself, the sensations of hearing, touch, sight give with equal directness an element of "voluminousness" involving in germ the knowledge of threedimension space. (2) Different points on the same sensitive surface give qualitatively different sensations (attention has been called to these differences by recent psychologists under the name of "local signs.") (3) Attention has further been called to the existence of special end-organs sensitive to motion which seem to give us immediate knowledge of extensity, apart from the tactual impression of the positions between which the motion takes place. ${ }^{1}$ (4) The analysis of the "muscular sensations" of the older psychology has been revolutionised by $(a)$ the denial of the existence of anything corresponding to the sense of innervation; (b) the distinction within muscular sensations proper of those which are due to the excitation of the sensitive surfaces of the joints and those which are due to the feelings of muscular contraction. This last distinction was not likely to escape Professor James, giving as it does an opening for the paradox which he is not slow to state, that instead of being the chief source of our knowledge of Space the sensations

$$
1 \text { JAMES, vol. ii. p. } 171 .
$$


of our contracting muscles "probably play as small a part in building up our exact knowledge of Space as any class of sensations which we possess." 1

Recent Sensationalism, of which Professor James is the prophet, has attempted to establish on the basis thus laid down the doctrine: (1) That a perception, not merely of extension but of Space in three dimensions, is given immediately in the primitive sensation; (2) that the particular Space relations of direction, position, distance, magnitude, are facts of the same order as the original data, ("they are nothing but sensations of particular lines, particular angles, particular forms of transitions, or-in the case of a distinct more-of particular outstanding portions of Space after two figures have been superposed")-in developing them no mysterious power of synthesis is required: discrimination, association, addition, multiplication, and division are sufficient; (3) that the conception of a larger Space which includes the given intuited spaces is obtained by a process of summation and abstraction - by the former we "straighten out" the chaotic presentations of the particular sense (adding to ABC DEF as outside and continuous with it), by the latter we drop out the several natures of the various fields and think only of their extents.

The question with which we started is, What value is to be attached to the Neo-Sensationalist position, thus barely sketched, as a reply to the Neo-Kantian doctrine of the a priori element implied in our knowledge of Space?

In attempting the briefest possible reply, I am tempted, in the first place, to ask whether in much that he lays down as to the original data of sense, Pro-

$$
{ }^{1} \text { Op. cit., p. } 197 .
$$


fessor James has not himself been guilty in some degree of the Psychologists' Fallacy against which he carries on elsewhere so unremitting a warfare. I find, at any rate, no attempt to distinguish, in those sensations which are said to carry "voluminousness" along with them, between the element which may be supposed to be primitive and the element which we supply from long experience in interpretation of it. Thus we are told that loud sounds have a certain enormousness of feeling; glowing bodies give us a perception which seems roomy; the tympanic membrane gives a sensation which is "distinctly and unmistakably one of vague spatial vastness in three dimensions." Granted that this is all true, how much of this enormousness, roominess, and vastness is due to the primitive datum? how much to association and analogical interpretation? If it is maintained that the sensation in its original form gives us "distinct and unmistakable" ideas of spatial relations in three dimensions, why, we may ask, should it not give us more information still? There is the colour which we call "high" because it gives us an idea not only of two dimensions, but of the relation between them; a cough which we call "hollow," because it gives us not only the idea of three dimensions, but of a vacuity contained by them; and a sigh which we call "deep" because of the further information that the vacuum is prolonged. Neo-Kantists are accused by Professor James of cherishing the doctrine of innate ideas, but compared with the mental apparatus for the interpretation of the physiological stimulus with which Neo-Sensationalism equips the primitive brain, the forms with which even the crudest form of the a priori doctrine endows us are the palest of abstractions.

I do not, however, mean to deny that extensity is 
given with the earliest recognisable sensations. On the contrary, I hold that it would be impossible to give any intelligible account of the development of knowledge at all unless the later is already implicitly given in the earlier. What the Neo-Kantist is interested in maintaining is that, granting the facts to be as alleged by recent psychologists, no one of them, nor all put together, can make it one whit the easier to prove that Space is given a posteriori in the sense that the knowledge of it is merely sensational. For-

1. At the lowest point at which we can take the presentation thought has already begun its work. The element of thought and the element of sense are given together. It is, of course, a mistake to represent the relating activity of thought as something induced upon the given material, as Professor James accuses the Platonisers of doing, but it is equally a mistake to make the relation of externality of parts, even at its lowest (and apart from such externality it is difficult to see what extensity could mean), a mere sensation. Professor James himself admits that the sensation comes "in the shape of a simple total vastness." But surely even the vaguest total is a total of parts, however vaguely they are in turn conceived. And such a relation of whole to parts is not a sensation, but the product of a thought which can hold differences apart and relate them to one another on the ground of an underlying identity. Go as low as you will, a totality or unity of vastness implies a plurality, nor can one form of the relation be given without calling into existence the other; one cannot be reduced to zero without annihilating its correlative. When, therefore, either is given (as upon the theory before us one at least is given) there must be taken with it something 
else which is not merely another given, but has its place beside it, or rather in it, by virtue of the nature of mind itself as a relating activity, and not by virtue of a further exercise of its receptive powers.

Professor James seeks to identify his doctrine in the chapter we have under review with Dr. Ward's, as developed in his article on "Psychology" in the Encyclopoedia Britannica; but Dr. Ward's has this merit in comparison with Professor James's, that it clearly recognises the relation of whole and part as implicitly given in the elementary presentation of extensity.

"Extensity," he says, "does imply plurality-we might call it latent or merged plurality, or a 'ground' of plurality, inasmuch as to say that a single presentation has massiveness is to say that a portion of the presentation continuum at the moment undifferentiated is capable of differentiation."

But this is not all: this totality, so far as it is a totality, is so in virtue of its being contained in a larger whole, and what has just been said of the element of diversity within the given continuum holds of the wider unity within which it is itself an element of difference. And this is equivalent to saying that not only the differences of position, direction, etc., but the universal conception of Space itself, is given implicitly along with the presentation continuum-in however elementary a form we conceive of it to exist.

2. These conclusions are still more obvious when we come to distinct Space relations, and need only be restated. It is here indifferent to Idealism how psychologists settle among themselves the vexed questions of the precise data out of which our knowledge of extension is built up, or of the inferential origin of the knowledge of the third dimension. What is essential 
to the position that it here takes up is to prove (i) that these relations are only intelligible as elements within a whole whose determinations they are, and (ii) that this relation of elements within a system by which they are determined, and which they determine in turn, is one that can subsist only for a consciousness which is not merely receptive of what is given, but by virtue of its constitution seeks, even at the level of external perception, such systematic unity as is possible at this stage. The world of spatially related objects is an ideal structure, reared and maintained at each moment by the activity of thought itself.

Professor James is quite conscious of the part that thought plays in sustaining around us a world of articulated space relations. Witness the passage ${ }^{1}$ ending with the words: "Obviously, for the orderly arrangement of a multitude of sense-spaces in consciousness, something more than their mere separate existence is required." It is only his Sensationalist assumptions (or shall we say prejudices?) that prevent him from recognising in this "something more" the differentiating and unifying function of thought itself and lead him, in what is perhaps the most unsatisfactory section of the whole book, to attempt to show how our idea of Space as a whole is built up by the mere addition and summation of a multitude of separate "sense-spaces."

3. This brings us to the last point: the Sensationalist account of the idea of Space in general. After what has been already said, a word is here sufficient. Mr. Spencer seems to regard it as a generalisation from particular experiences got by way of abstraction in the orthodox manner. Professor James supposes it to be

1 Loc. cit., p. 146. 
obtained by a process of smoothing out and filling in empirically given sense-spaces. If what has been already said be true, it is clear that neither account is wholly satisfactory. Unless the general conception of homogeneous extension is already latent in the first apprehension of an extended surface, no process of abstraction from given parts, still less of piecemeal addition of them, can give it to us. To suppose that either of them can is to continue the mistake of confusing the abstract or inert universal, created by a process which is either merely analytic or merely synthetic for some arbitrarily chosen end, and which adds nothing to our knowledge with the concrete universal which is a necessary element in the knowledge of the particular, in however primitive a form we conceive of that knowledge as existing, and grows into distinctness as the particulars themselves become distinct.

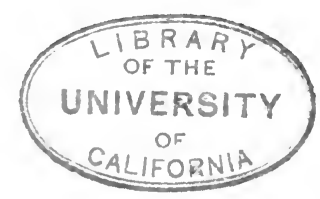






$$
-
$$




\section{UNIVERSITY OF CALIFORNIA LIBRARY BERKELEY}

Return to desk from which borrowed.

This book is DUE on the last date stamped below.

\section{JAN 281948}

$5 \operatorname{Lan} 54 \mathrm{VL} . X$

\section{REGEIVED}

I?" $3 \because \cdots \cdot P M$

LOAN BOET.

MAR $\left.7 \cdot 67^{-1}\right)$ PM

lomp nept.

JUN 171969 
YC1D a d d in
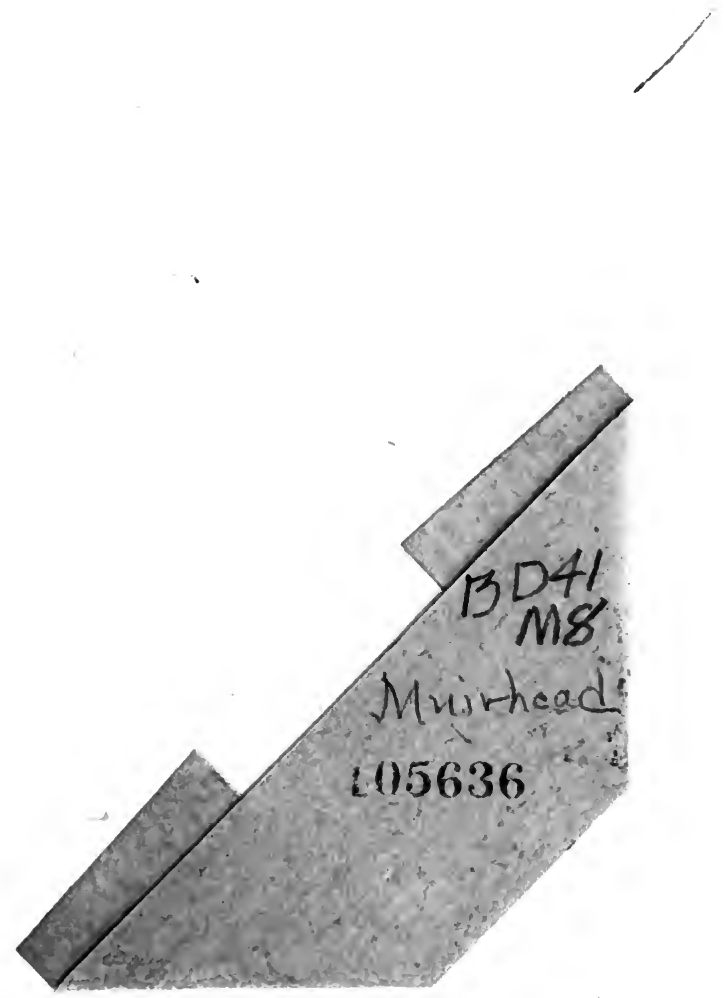

$\because$ 
